UNIVERSIDADE DE SÃO PAULO

FACULDADE DE MEDICINA DE RIBERÃO PRETO

PÓS-GRADUAÇÃO EM IMUNOLOGIA BÁSICA E APLICADA

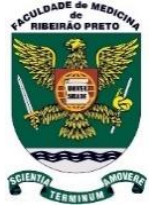

STELLA FRANCY VICENTE DE ASSUNÇÃO

Papel do Receptor de Succinato 1 (SUCNR1/GPR91) na Imunopatologia da Psoríase

RIBEIRÃO PRETO 
STELLA FRANCY VICENTE DE ASSUNÇÃO

Versão corrigida. A versão original encontra-se disponível tanto na Biblioteca da Unidade que aloja o Programa, quanto na Biblioteca Digital de Teses e Dissertações da USP (BDTD)”

\section{Papel do Receptor de Succinato 1 (SUCNR1/GPR91) na Imunopatologia da Psoríase}

Dissertação apresentada ao Programa de Pós-Graduação em Imunologia Básica e Aplicada da Faculdade de Medicina de Ribeirão Preto da Universidade de São Paulo para obtenção do título de Mestre em Ciências.

Área de Concentração:

Imunologia Básica e Aplicada

Orientador:

Prof. Dr. José Carlos Farias Alves Filho 
Autorizo a reprodução e divulgação total ou parcial deste trabalho, por qualquer meio convencional ou eletrônico, para fins de estudo e pesquisa, desde que citada a fonte

\section{FICHA CATALOGRÁFICA}

de Assunção, Stella Francy Vicente

Papel do Receptor de Succinato 1 (SUCNR1/GPR91) na Imunopatologia da Psoríase Ribeirão Preto, 2020. 74 fls.

Dissertação de mestrado apresentada ao Programa de Pós-Graduação em Ciências. Área de concentração: Imunologia Básica e Aplicada. Faculdade de Medicina de Ribeirão Preto da Universidade de São Paulo.

Orientador: José Carlos Farias Alves Filho

1. Psoríase; 2. succinato; 3. SUCNR1; 4. GPR91; 5. queratinócitos. 


\section{FOLHA DE APROVAÇÃO}

Nome: de Assunção, Stella Francy Vicente

Título: Papel do Receptor de Succinato 1 (SUCNR1/GPR91) na Imunopatologia da Psoríase

Dissertação apresentada ao Programa de Pós-Graduação em Imunologia Básica e Aplicada da Faculdade de Medicina de Ribeirão Preto da Universidade de São Paulo para obtenção do título de Mestre em Ciências.

Área de Concentração:

Imunologia Básica e Aplicada

Aprovado em 06 de outubro de 2020

BANCA EXAMINADORA:

Prof. Dr. José Carlos Farias Alves Filho

Orientador

Dra. Cacilda da Silva Souza

Membro da Casa

Prof. Dr. Flávio Almeida Amaral

Membro de Fora 
Trabalho realizado no Laboratório de Inflamação e Dor do Departamento de Farmacologia da Faculdade de Medicina de Ribeirão Preto da Universidade de São Paulo com auxílio financeiro da Fundação de Amparo à Pesquisa do Estado de São Paulo (FAPESP), do Conselho Nacional de Desenvolvimento Tecnológico (CNPq) e da Coordenação de Aperfeiçoamento de Pessoal de Nível Superior (CAPES) 
À minha mãe,

Ana Maria 


\section{AGRADECIMENTOS}

Ao meu orientador Prof. Dr. José Carlos Farias Alves Filho pela oportunidade, confiança, disposição em me ensinar e especialmente pelas críticas construtivas, pois são elas que me permitem me tornar uma profissional melhor. Agradeço também por me estimular a sempre ter pensamento crítico e a questionar o porquê de tudo o que estou fazendo. Estou encerrando esta etapa com uma maturidade científica e capacidade técnica que não teria se não tivesse sido sua aluna.

Ao meu co-orientador Dr. Flávio Protásio Veras pela prontidão e paciência em me ensinar o modelo de psoríase, diversas das técnicas que aprendi durante mestrado e por ter me apoiado em tantos momentos da minha vida pessoal e profissional. Muito obrigada por ter insistido e investido seu tempo em mim.

À minha co-orientadora Dra. Daniele de Carvalho Bernardo Nascimento por me ensinar a trabalhar com foco e determinação, pelos inúmeros conselhos e pelo apoio que me ofereceu ao longo dessa jornada. Não consigo expressar em palavras minha gratidão por você, mas como tentativa, muito obrigada por ter acreditado em mim e me estendido a mão quando precisei.

Ao Ms. Gabriel Azevedo Públio por ter me acompanhado desde o princípio me dando suporte, me ensinando e errando cálculos comigo. Ao Ms. Marcos Henrique Rosa pela contribuição em algumas coletas e pelos momentos de descontração e muitas risadas. À Thainá Norbiato Silva por ter iniciado este projeto com trabalho duro e muita dedicação.

Ao Ms. Douglas da Silva Prado por ter me ensinado algumas das técnicas utilizadas na realização deste projeto, pela disposição em ensinar e por sempre receber com tanta educação e gentileza novos alunos. Ao Ms. Francisco Isaac pela contribuição indireta para realização deste projeto, sempre me emprestando reagentes comuns ao nosso projeto e me dando dicas. Ao Ms. Atlante por me ajudar nos ensaios de RNAScope. A todos os colegas de laboratório que contribuíram de alguma maneira para realização deste trabalho e para minha formação.

Ao Prof. Dr. Fernando de Queiroz Cunha pelo Centro de Pesquisa em Doenças Inflamatórias (CRID), por oferecer aporte financeiro e estrutura física para realização de tantos trabalhos, incluindo este. Ao Prof. Dr. Thiago de Mattar Cunha do Laboratório de Inflamação e Dor (LID) por compartilhar estrutura física, reagentes e conhecimentos. Ao Prof. Dr. João Santana da Silva da FIOCRUZ-SP por emprestar estrutura física, equipamentos e reagentes para realização deste trabalho.

Aos técnicos do LID Sérgio, Kátia, Marcela, Diva e Juliana por propiciarem as condições necessárias para o desenvolvimento de pesquisa no laboratório. Em especial à Ieda 
Regina por me ajudar em ensaios de perfusão e ter realizado o transplante de medula óssea no ensaio de quimera, pela conduta ética impecável e conselhos valiosos e ao Sr. Tadeu por ter realizado todas as histologias de H\&E deste trabalho com tanta delicadeza e dedicação.

Ao programa de pós-graduação em Imunologia Básica e Aplicada (IBA). Às agências de fomento Conselho Nacional de Desenvolvimento Científico e Tecnológico (CNPq), Coordenação de Aperfeiçoamento de Pessoal de Nível Superior (CAPES) e Fundação de Amparo à Pesquisa do Estado de São Paulo (FAPESP).

Ao Prof. Dr. João Santana da Silva e a Profa. Dra. Beatriz Rossetti Ferreira da disciplina de Imunologia Celular por nos ensinarem a sempre questionar, como raciocinar cientificamente e ter pensamento crítico, sem ofender o próximo. Concluímos a disciplina diferentes de quando iniciamos e com certeza somos definidos como antes e depois dessa experiência. À Ana Cristine, secretária do programa de pós-graduação em Imunologia Básica e Aplicada (IBA), pela disponibilidade de sempre nos ajudar quando precisamos.

Aos amigos que o LID me proporcionou, em especial ao Ferreirinha, ao Prots, a Dani, a Vanessa e o Mika por me terem me recebido tão bem no laboratório e em Ribeirão Preto, por serem pessoas tão queridas e sempre dispostas a ajudar o próximo. Aos amigos que o IBA me proporcionou, Lili, Alex, Pri, João e em especial Valter e Rafael por me lembrarem o quanto pode ser divertido e construtivo trabalhar em grupo. Muito obrigada a todos por tornarem minha caminhada muito mais agradável e por formarem uma rede de apoio com a qual posso sempre contar.

Ao meu cachorro Ferreirinha pelo privilégio de ser sua mamãe, pelo carinho em me receber em casa todos os dias depois de mais um longo período de trabalho, pelas brincadeiras e travessuras que me enchem de alegria e iluminam meus dias.

Por último e mais importante a minha mãe pelo exemplo de ser humano, mãe, mulher e profissional que desejo me tornar algum dia. Por ter me ensinado a valorizar as pequenas coisas, mas a correr atrás das grandes, a nunca me contentar com o que não me acrescenta ou não me deixa feliz, mas a ser grata e reconhecer o ensinamento em toda e qualquer experiência, a me levantar mais forte e seguir em frente após cada tropeço. Por ser uma mãezona e uma guerreira. Por sempre acreditar em mim, me incentivar e me ensinar a trilhar meu próprio caminho. Por todo o apoio ao longo da minha vida, inclusive na minha decisão de seguir carreira acadêmica e de vir pra tão longe em busca desse objetivo. 
“Agora, aqui, veja, é preciso correr o máximo possível para permanecer no mesmo lugar Se você deseja chegar em um lugar diferente deve correr pelo menos duas vezes mais rápido que isso"

- Rainha Vermelha, Através do Espelho Lewis Carroll, 1871 


\section{RESUMO}

ASSUNÇÃO, SFV. Papel do Receptor de Succinato 1 (SUCNR1/GPR91) na Imunopatologia da Psoríase. 2020. 74 fls. Dissertação (Mestrado) - Faculdade de Medicina de Ribeirão Preto, Universidade de São Paulo, Ribeirão Preto, 2020.

O succinato é um ácido dicarboxílico intermediário do ciclo de Krebs que desempenha uma função importante no metabolismo energético celular. Além de suas funções metabólicas, o succinato também realiza diversas funções ao interagir com seu receptor de membrana denominado Sucnr1, o qual é expresso em diversos tipos celulares. No sistema imune, foi demostrado que o Sucnr1 é principalmente expresso em células dendríticas (DCs), sendo envolvido com a ativação e migração destas células. Tendo em vista que as DCs são primordiais para o desenvolvimento e manutenção do processo inflamatório na psoríase e, consequentemente em seu modelo experimental, postulamos que a expressão do Sucnr1 por DCs imaturas induz a ativação e migração destas para linfonodos drenantes (dLNs) onde induzem células produtoras de IL-17, as quais ativam queratinócitos e amplificam o processo inflamatório na pele provocando lesões e cronicidade da doença. Desta forma, propomos investigar o papel do Sucnr1 no contexto de psoríase, se o receptor contribui para severidade e de que forma atua na doença. Acreditamos que na pele psoriática a expressão do Sucnr1 por DCs induz a migração destas para dLNs onde induzem populações de células produtoras de IL17. Primeiro verificamos que o Sucnrl é positivamente modulado no modelo experimental de psoríase, depois induzimos psoríase em camundongos C57BL/6 (WT) e nocauteados para Sucnr1 (SUCNR1 ${ }^{-/}$), nos quais observamos redução de aspectos clínicos, histológicos e inflamatórios na pele de animais SUCNR1 ${ }^{-/}$. Em seguida investigamos a expressão do Sucnr1 por DCs e demais leucócitos e verificamos que demais leucócitos apresentam mais expressão do receptor do que DCs. Avaliamos então a expressão do Sucnrl por células de origem hematopoiética e células de origem não-hematopoiética e verificamos que células de origem não-hematopoiética apresentam elevada expressão do Sucnrl. Para avaliar se a expressão do Sucnr1 por células de origem não-hematopoiética ou de origem hematopoiética é biologicamente mais relevante na psoríase experimental, realizamos um ensaio quimera e constatamos que quando as células de origem não-hematopoiéticas expressam o receptor, a psoríase se desenvolve independente de os leucócitos expressarem ou não o Sucnr1. Observamos que tanto o Sucnrl quanto o Sucnr1 são expressos por queratinócitos. Quando tratamos animais com um creme $3 \%$ de succinato, estes desenvolveram aumento na espessura da pele. Os queratinócitos, células residentes da epiderme, apresentam elevada expressão de Sucnr1 na pele psoriática e o receptor contribui para manutenção do processo inflamatório.

Palavras-chave: 1. Psoríase; 2. succinato; 3. SUCNR1; 4. GPR91; 5. queratinócitos. 


\begin{abstract}
ASSUNÇÃO, SFV. Role of Succinate Receptor (SUCNR1/GPR91) in the Immunopathology of Psoriasis. 2020. 74 fls. Thesis (MSc) - School of Medicine of Ribeirão Preto University of São Paulo, Ribeirão Preto, 2020.

Succinate is a dicarboxylic acid intermediary of Krebs cycle that plays an important role in cellular energetic metabolism. Besides its metabolic functions, succinato also performs different functions in binding with its membrane receptor called Sucnr1, which is expressed in different cell types. In the immune system, it has been demonstrated that Sucnr1 is mainly expressed by Dendritic Cells (DCs), it is involved with its activation and migration. As DCs are primordial to the development and maintenance of the inflammatory process in Psoriasis and therefore its experimental model, we postulate that Sucnr1 expression by immature DCs induces their activation and migration to draining lymph nodes (dLNs) where they induce producing IL-17 cells, which activate keratinocytes and amplified the skin inflammatory process causing lesions and the chronicity of the disease. We propose to investigate Sucnr1 role in Psoriasis context if the receptor contributes to the severity and which way it operates in the disease. We believe that in psoriatic skin Sucnr1 expression by DCs induces its migration to dLNs where they induce producing IL-17 populations. First, we verified that Sucnr1 is positively modulated in psoriasis experimental model. After we induced psoriasis in mice C57BL/6 (WT) and knockout to Sucnr1 (SUCNR1 ${ }^{-/}$), in which we observed reduction in clinical, histological and inflammatory aspects of the skin in SUCNR $1^{-/-}$mice. We investigated Sucnrl expression by DCs and other leucocytes in the skin and we saw that other leucocytes express more Sucnrl than DCs. We then investigated Sucnrl expression by cells of hematopoietic origin or nonhematopoietic origin and we observed that cells of nonhematopoietic origin express more Sucnrl. To evaluate if its expression by cells of nonhematopoietic or hematopoietic origin is biological more relevant in experimental psoriasis, we performed a chimera essay and observed that mice that had resident skin cells expressing the receptor developed psoriasis normally regardless of their leucocytes express or not Sucnr1. Observed that Sucnrl and Sucnrl are expressed by keratinocytes. When we treated animals with $3 \%$ succinate cream, they present increased thickness of their skin. Keratinocytes, skin resident cells, highly express Sucnr1 in psoriatic skin and the receptor contribute to the maintenance of the inflammatory process.
\end{abstract}

Keywords: 1. Psoriasis; 2. succinate; 3. SUCNR1; 4. GPR91; 5. keratinocytes. 


\section{LISTA DE FIGURAS}

FIGURA 1 - Estrutura e composição celular da pele .............................................................. 2

FIGURA 2 - Manifestações clínicas da psoríase ............................................................. 10

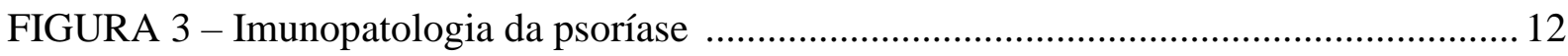

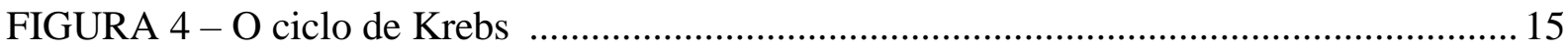

FIGURA 5 - Expressão de Sucnr1 no modelo experimental de psoríase ...............................2 27

FIGURA 6 - Participação do Sucnr1 na indução de edema, eritema e descamação na pele na

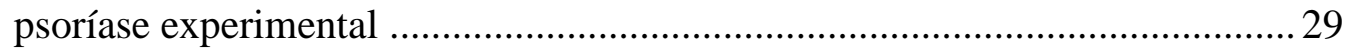

FIGURA 7 - Peso corpóreo e do baço dos animais durante a indução de psoríase com IMQ 30

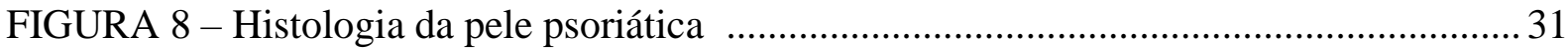

FIGURA 9 - Marcadores de ativação de queratinócitos na psoríase experimental ................ 32

FIGURA 10 - Células $\mathrm{T} \alpha \beta$ produtoras de IL-17 na ausência do Sucnr1 em modelo experimental de psoríase ....................................................................... 33

FIGURA 11 - Células T $\gamma \delta$ produtoras de IL-17 na ausência do Sucnr1 em modelo experimental

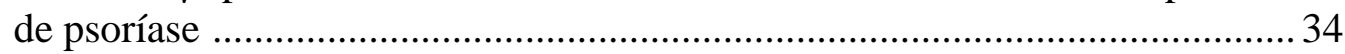

FIGURA 12 - Citocinas inflamatórias na pele e no soro de animais na psoríase experimental

FIGURA 13 - Expressão de Sucnrl em células dendríticas na pele psoriática 37

FIGURA 14 - Expressão de Sucnr1 em células hematopoiéticas e não-hematopoiéticas na pele psoriática

FIGURA 15 - Repercussão do Sucnr1 em espessura, eritema e descamação na pele de animais quimera tratados com IMQ

FIGURA 16 - Expressão de $K 17$ em animais quimera tratados com IMQ ............................ 40

FIGURA 17 - Histologia da orelha de animais quimera tratados com IMQ .......................... 41

FIGURA 18 - Expressão do Sucnrl por queratinócitos ................................................... 42

FIGURA 19 - Expressão do Sucnr1 por queratinócitos ..................................................... 43

FIGURA 20 - Espessura, eritema e descamação na pele de animais após tratamento tópico com creme de succinato 
FIGURA 21 - Espessura, eritema e descamação da pele de animais SUCNR1 ${ }^{-1-}$ tratados com

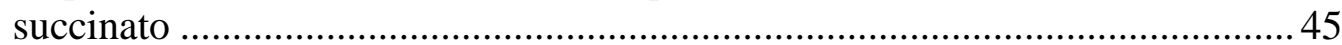




\section{LISTA DE SIGLAS E ABREVIATURAS}

$\mu \mathrm{g}$ - micrograma

$\mu \mathrm{L}-$ microlitro

AP-1 - Proteína Ativadora 1

APC - Células Apresentadoras de Antígeno

ATP - Adenosina Trifosfato

$\mathrm{Ca}^{2+}$ - Cálcio

CCR - Receptor de Quimiocina C-C

CD - Cluster de Diferenciação

cDNA - DNA Complementar

CEUA - Comissão de Ética no Uso de Animais

CLA - Antígeno Associado a Linfócitos

$\mathrm{cm}^{2}$ - Centímetros quadrados

$\mathrm{CO}_{2}$ - Dióxido de Carbono

CoA - Coenzima A

CONCEA - Conselho Nacional de Controle de Experimentação Animal

CTGF - Fator de Crescimento do Tecido Conectivo

CXCL - Motivo C-X-C ligante

DCs - Células Dendríticas

dDCs - Células Dendríticas Dermais

DM - Domínio Metaloproteinase

DMEM - Meio Dulbecco MEM

DNA - Ácido Desoxirribonucleico

DO - Densidade Óptica

DRC - Domínio Rico em Cisteína

DSD - Domínio Semelhante a Desintegrina

dsRNA - RNA de Fita Dupla

eGFP - do inglês enhanced green fluorescent protein, proteína verde fluorescente enriquecida

ELISA - do inglês Enzyme Linked ImmunonoSorbent Assay, Ensaio Imunoenzimático

FACs - do inglês fluorescence activated cell-sorting, sorteio celular por fluorescência ativada

FC - Fragmento Cristalizável

FGF - Fator de Crescimento de Fibroblasto

GFP - do inglês Green Fluorescente Protein, Proteína Verde Fluorescente 
GM-CSF - Fator Estimulador de Colônia Macrófago-Granulócito

GPCR - Receptor Acoplado a Proteína G

GPR91 - Receptor Acoplado a Proteína G 91

H\&E - Hematoxilina e Eosina

hBD - $\beta$-defensina humana

HIV - Vírus da Imunodeficiência Humana

IFN - Interferon

Ig - Imunoglobulina

IGF - Fator de Crescimento Semelhante a Insulina

$\mathrm{IL}$ - Interleucina

IL- Interleucina

IMQ - Imiquimode

IRF - Fator Regulatório de Interferons

K - Citoqueratina

$\mathrm{kDa}$ - Quilo Dalton

KGF - Fator de Crescimento de Queratinócitos

KO - do inglês Knockout, Nocaute

LC - Células de Langerhans

LCN2 - Lipocalina 2

LPS - Lipopolissacarídeo

LTA - Ácido Lipotecoico

$\mathrm{mA}$ - Miliampère

MEC - Matriz Extracelular

MHC - Complexo de Histocompatibilidade Principal

$\mathrm{mL}$ - mililitro

MO - Medula Óssea

MoDCs - Células Dendríticas derivadas de Monócitos

mRNA - RNA Mensageiro

mTOR - Rampamicina

NETs - Armadilhas Extracelulares de Neutrófilos

NF-кB - Fator Nuclear-Kappa B

nm - nanômetro

${ }^{\circ} \mathrm{C}$ - Celsius

PAMP - Padrão Molecular Associado a Patógeno 
PBMC - do inglês peripheral blood mononuclear cell, células mononucleadas do sangue periférico

PBS - Tampão Fosfato-Salino

PD-1 - Proteína de Morte Celular Programada

pDCs - Células Dendríticas Plasmocitóides

PFA - Paraformaldeído

PGE2 - Prostaglandina

PRR - Receptor de Reconhecimento de Padrão

qRT-PCR - Reação em Cadeia da Polimerase em Tempo Real

RNA - Ácido Ribonucleico

rpm - Rotações por Minuto

ssRNA - RNA de Fita Simples

STAT - Transdutor de Sinal e Ativador de Transcrição

SUC - Succinato

Sucnr1 - Receptor de Succinato 1

TCR - Receptor de Células T

TGF- $\beta$ - Fator de Crescimento Transformante Beta

$\mathrm{T}_{\mathrm{H}}-\mathrm{T}$ auxiliar

TLR - Receptor Semelhante a Toll

TNF - Fator de Necrose Tumoral

Treg - T Reguladora

TRIF - proteína adaptadora Domínio-TIR-Contendo-Adaptador-Induzindo-Interferon- $\beta$

UV - Ultravioleta

WT - do inglês Wildtype, Selvagem 


\section{SUMÁRIO}

1. INTRODUÇÃO

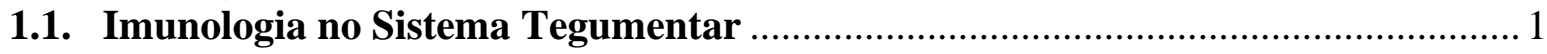

1.1.1. Aspectos Gerais do Sistema Tegumentar ............................................... 1

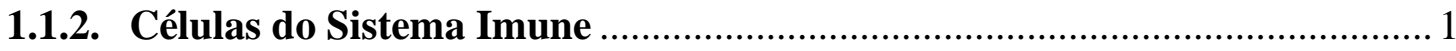

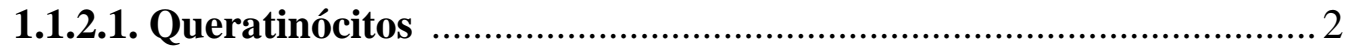

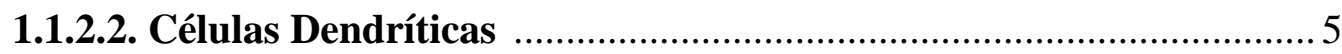

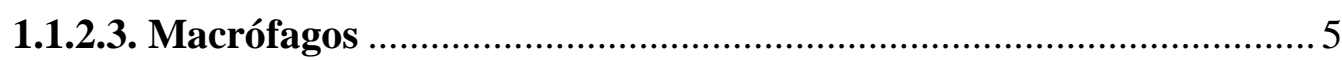

1.1.2.4. Neutrófilos

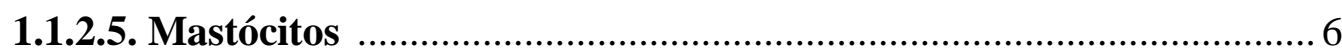

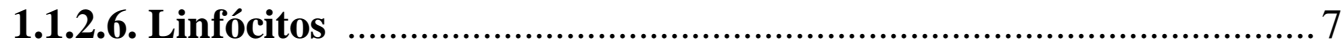

1.1.2.7. Linfócitos Não-Convencionais .................................................... 8

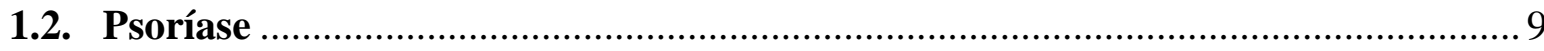

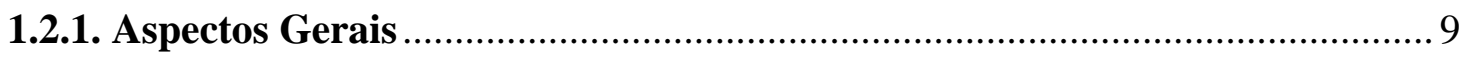

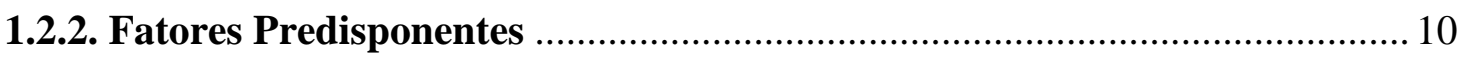

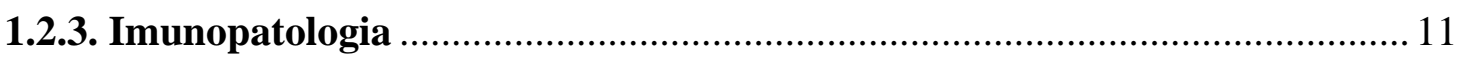

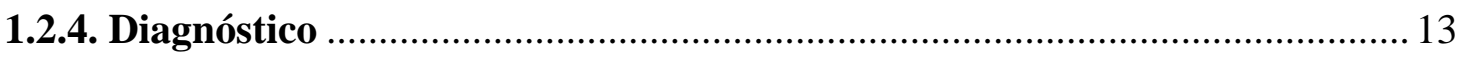

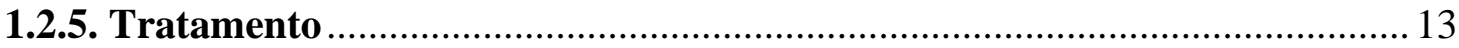

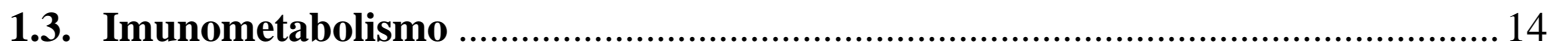

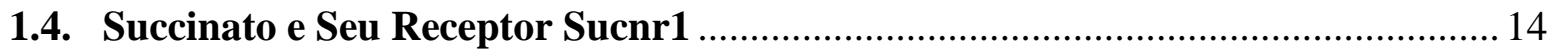

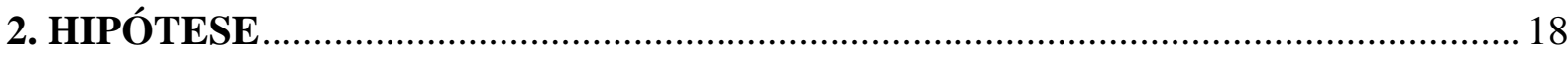

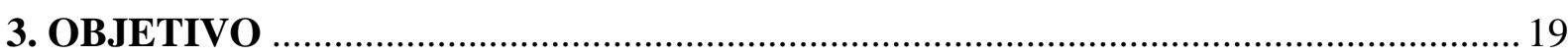

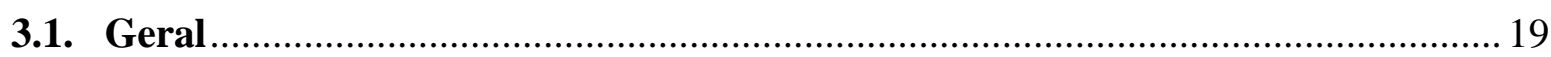

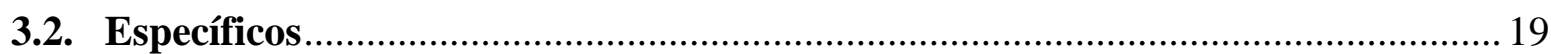

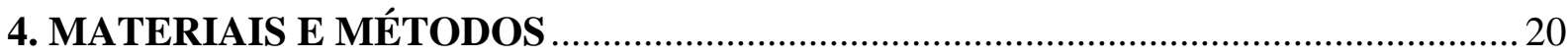

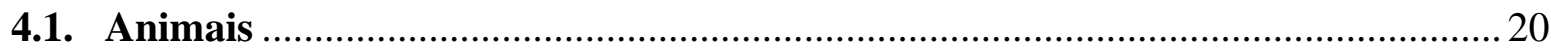

4.2. Modelo de Inflamação da Pele Induzida por Imiquimode ................................... 20

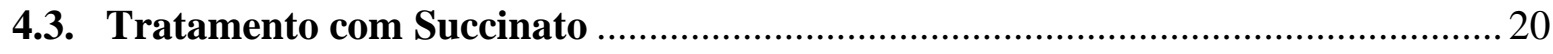

4.4. Modelo de Construção de Camundongos Quimera ............................................ 20

4.5. Cultura de Queratinócitos Humanos Imortalizados (HaCaT) ............................ 21

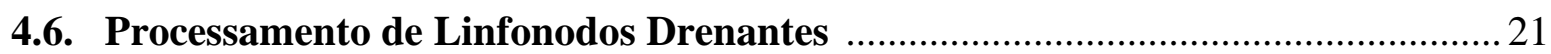

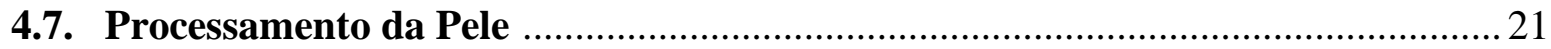

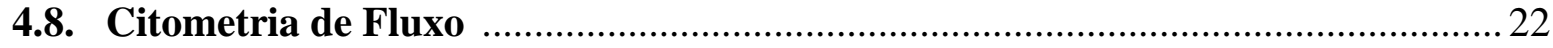

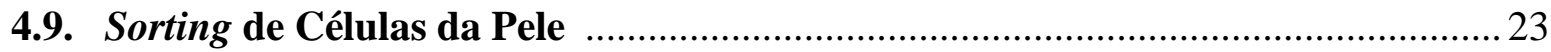

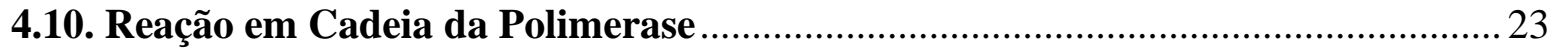

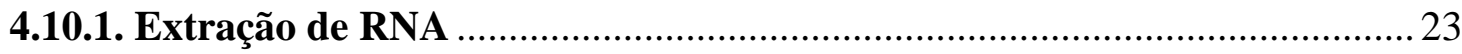




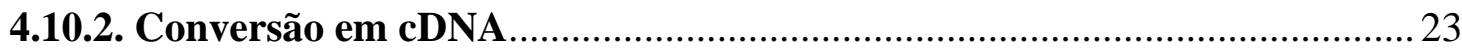

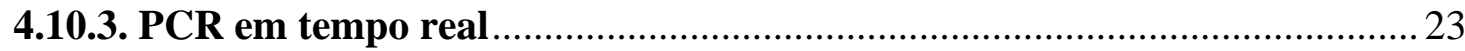

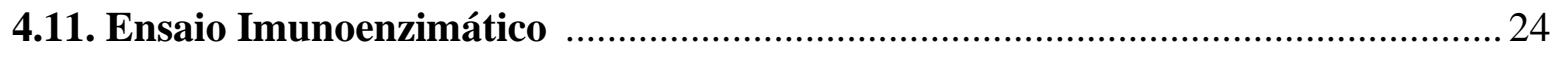

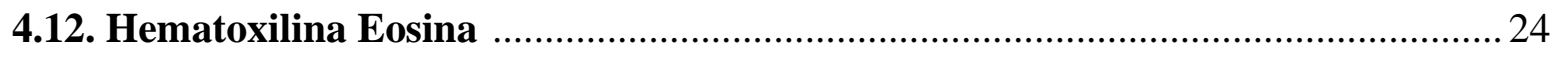

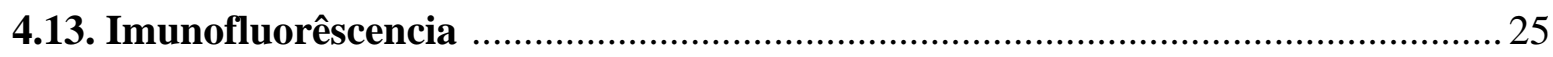

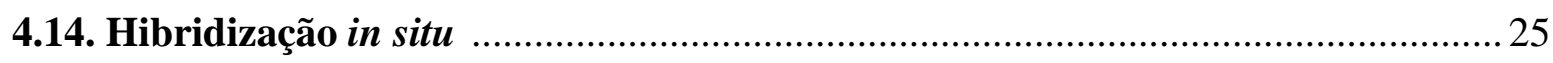

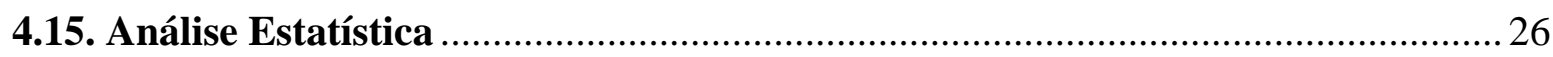

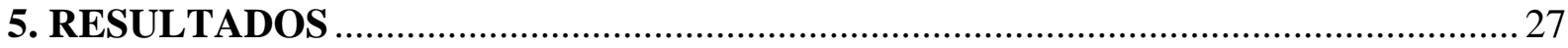

5.1. A expressão de Sucnrl está aumentada no modelo experimental de psoríase ..... 27

5.2. O Sucnr1 contribui para o aumento na espessura e no eritema da pele induzidos

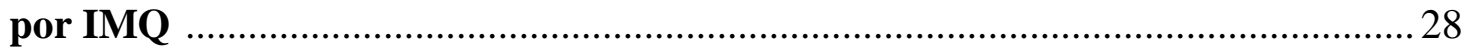

5.3. O Sucnr1 contribui para o aumento de edema, infiltrado inflamatório, acantose, hiperqueratose e paraqueratose no modelo experimental de psoríase 30

5.4. O Sucnr1 contribui para modulação de marcadores de ativação dos queratinócitos induzidos pelo IMQ

5.5. O Sucnr1 contribui para expansão de células produtoras de IL-17 nos linfonodos na psoríase experimental

5.6. O Sucnr1 contribui para expressão de citocinas inflamatórias na pele e no soro de animais induzidos com IMQ

5.7. O Sucnr1 é majoritariamente expresso por células não-hematopoiéticas. 35

5.8. A expressão de Sucnr1 por células não-hematopoiéticas é biologicamente mais relevante para desenvolvimento da psoríase experimental 38

5.9. O Sucnr1 expresso por células de origem não-hematopoiéticas na pele contribui para o aumento de hiperqueratose, acantose e paraqueratose na psoríase experimental

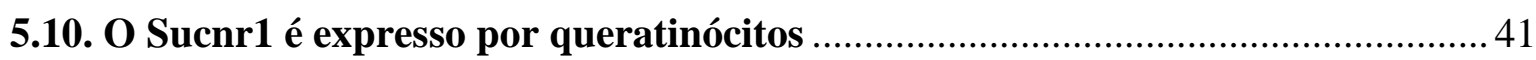

5.11. O tratamento tópico com succinato induz aumento na espessura da pele ......... 43

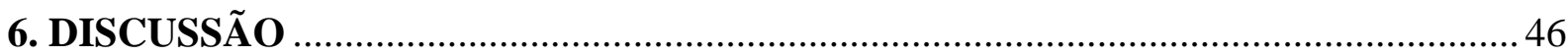

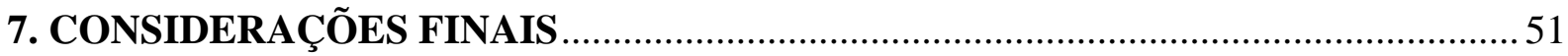

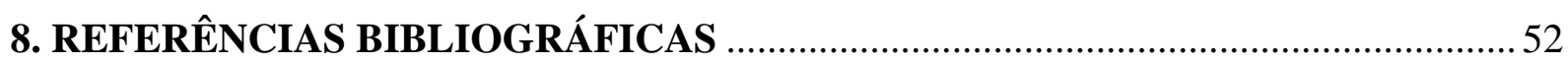

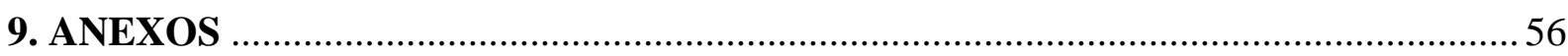

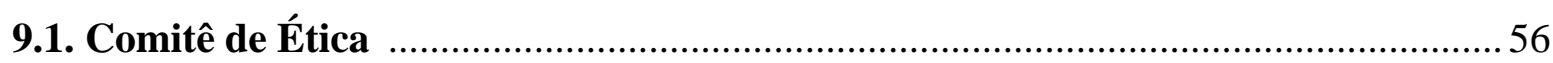




\section{INTRODUÇÃO}

\subsection{Imunologia no Sistema Tegumentar}

\subsubsection{Aspectos Gerais do Sistema Tegumentar}

O sistema tegumentar é composto pela pele e seus anexos, como cabelos, pelos, unhas e glândulas sebáceas e sudoríparas. Trata-se do maior órgão do corpo humano, possui cerca de $65 \%$ do peso corporal e $16 \mathrm{mil} \mathrm{cm}^{2}$, atua na termorregulação, impede a perda de água, protege o organismo contra impactos físicos, raios ultravioletas, agentes químicos e microorganismos. Enquanto principal barreira entre organismo e o meio externo desempenha um papel essencial para homeostasia ao prevenir infecções e tolerar agentes comensais, para tanto, conta com um sistema imunológico altamente especializado (Wickett, Visscher, 2006; Boer et al., 2016).

Morfologicamente, a pele é composta por três camadas: epiderme, derme e hipoderme. A epiderme é um epitélio estratificado escamoso de origem no ectoderma, é composta por vários tipos celulares, tais como: queratinócitos, células mais abundante presente na epiderme, células dendríticas especializadas chamadas células de Langerhans, macrófagos, mastócitos e linfócitos. A principal função da epiderme é de barreira física e química contra agentes externos, e de barreira imunológica contra microorganismos potencialmente patogênicos. A epiderme não possui inervação nem mesmo suprimento sanguíneo, sendo dividida em cinco subcamadas: estrato basal, estrato espinhoso, estrato granuloso, estrato lúcido e estrato córneo (Figura 1) (Kanitakis, 2002; Wickett, Visscher, 2006, Wong et al., 2015).

A derme possui origem no mesoderma, seus principais componentes são fibras de colágeno e de elastina produzidas por fibroblastos também presentes nessa camada, possui uma diversidade de células dendríticas chamadas plasmocitóides e dermais, macrófagos, mastócitos e linfócitos (Figura 1). Ela é subdividida em camada papilar e reticular, a primeira é constituída por fibras, inervação e vascularização esparsas e transporta nutrientes passivamente para epiderme, à qual é adjacente, a segunda é constituída por fibras, inervação e vascularização densa, é adjacente à derme. Assim como a derme, a hipoderme se origina do mesoderma, é composta por tecido adiposo, possuindo função de armazenar energia e de termorregulação e possui inervação e vascularização (Kanitakis, 2002; Wickett, Visscher, 2006; Wong et al., 2015).

\subsubsection{Células do Sistema Imune}

As diferentes camadas da pele são constituídas por diversos tipos celulares o que resulta nas diferentes funções desempenhadas por cada uma. Ao passo em que a epiderme constitui barreira física e química, também atua no reconhecimento às sustâncias com as quais entra em contato o tempo todo e ativa uma resposta imune chamada tolerogênica, cuja principal função 
é de não responsividade a microorganismos comensais, com os quais vivem uma relação de simbiose /ou à partículas não patogênicas. Para que a resposta imune na derme seja iniciada, as barreiras da epiderme precisam ser de alguma maneira vencidas, desta forma, as células do sistema imune da epiderme e da derme atuam em conjunto, desempenhando uma função de proteção contra antígenos potencialmente patogênicos, e uma vez ativada, inicia-se a inflamação (Nestle et al., 2009; Coates, Blanchard, MacLeod, 2018).

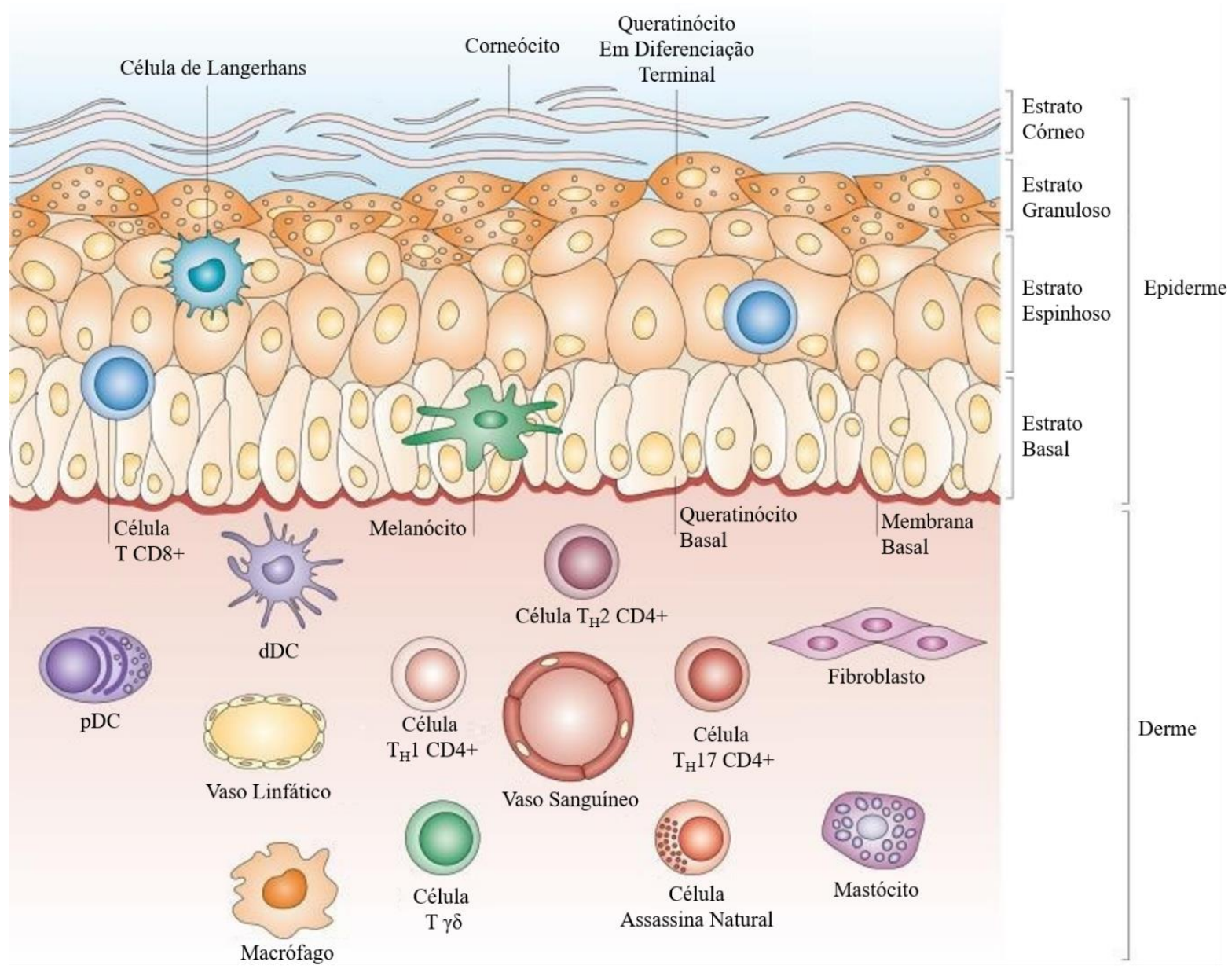

Figura 1. Estrutura e composição celular da pele. A pele é composta pela epiderme, derme e hipoderme (não mostrada). A epiderme é subdividida em estratos basal, onde queratinócitos estão em constante proliferação, estrato espinhoso, granuloso e córneo, composto por corneócitos, queratinócitos mortos, ricos em queratina e anucleados. A epiderme conta ainda com células dendríticas especializadas, as células de Langerhans, linfócitos T CD8+ e melanócitos, que absorvem radiações ultravioletas. Na derme existe uma maior variedade de células imune, células dendríticas plasmocitóides (pDCs), demais (dDCs), células T auxiliares de diversos subtipos, assassinas naturais, mastócitos, fibroblastos e vasos linfáticos e sanguíneos. Adaptado de Nestle et al 2009.

\subsubsection{Queratinócitos}

Os queratinócitos compõem cerca de $90 \%$ da epiderme, se originam de células progenitoras no estrato basal e em cada estrato se encontram em um período diferente de 
maturação. Ou seja, os diferentes estratos epidérmicos são formados de acordo com a maturação e diferenciação dos queratinócitos. No estrato espinhoso os queratinócitos ganham forma hexagonal e começam a produzir fibras de queratina. O estrato granuloso é assim denominado pois os queratinócitos deste estrato possuem grânulos chamados corpos lamelares que são ricos em lipídeos e peptídeos com propriedades antimicrobianas, é também onde começam a perder núcleo e organelas. O estrato lúcido é ausente na maioria das regiões do corpo, à exceção das palmas e plantas, é onde os queratinócitos perdem núcleo e organelas e ganham forma plana. No estrato córneo os queratinócitos são células mortas, chatas, anucleadas, sem organelas e repletos de fibras de queratina, cuja principal função é de barreira, impedindo o contato de agentes externos com células vivas, sendo chamados de corneócitos. O período entre a origem e a morte de um queratinócito é denominado de turnover e leva em torno de 28 dias em uma pele saudável (Suter et al., 1996; Kirfel, Herzof, 2004;).

Apesar de ainda hoje não serem considerados células do sistema imunológico, os queratinócitos são responsáveis por iniciar e manter processos inflamatórios na pele. Os queratinócitos produzem peptídeos antimicrobianos de três principais famílias: defensinas, catelicidinas e RNAse 7. As principais defensinas são as $\beta$-defensinas, proteínas positivamente carregadas que penetram na bicamada lipídica da membrana celular criando poros que resultam em lise, além disso, a $\beta$-defensina humana (hBD) 2 é capaz de se ligar ao receptor da quimiocina (CCR) 6 e atrair células dendríticas e linfócitos para o local iniciando ou mantendo uma inflamação. A hBD2 é capaz ainda de induzir influxo de cálcio $\left(\mathrm{Ca}^{2+}\right)$ em mastócitos resultando na liberação de seus grânulos contendo histamina. A catelicidina de maior importância para este trabalho é o LL-37, que é produzida por queratinócitos e neutrófilos, atua em sinergia com defensinas e é capaz de recrutar neutrófilos, macrófagos e linfócitos. A RNAse 7 apresenta atividade de ribonuclease, catalisa RNA presente no espaço extracelular (Pivarcsi, Nagy, Kemeny, 2005; Nguyen, Soulika, 2019).

Os queratinócitos expressam Receptores de Reconhecimento de Padrão (PRR) que reconhecem padrões moleculares inerentes à determinados grupos de microorganismos, os Padrões Moleculares Associados À Patógeno (PAMP). Dentre os PRR, os Receptores Semelhantes à Toll (TLR) 1, 2, 3, 4, 5, 6 e 9 foram descritos em queratinócitos, de maneira que o TLR-2 e o TLR-6 são expressos na superfície celular e reconhecem ácido lipotecoico (LTA) expresso por bactérias Gram-positivas e o zymosan expresso por fungos; o TLR-3 é expresso nos endossomas e reconhece RNA de fita dupla (dsRNA) expresso apenas por vírus; o TLR-4 é expresso na membrana da superfície celular e associado à proteína CD14 ou MD-2 reconhece lipopolissacarídeo (LPS), expresso por bactérias Gram-negativas; o TLR-5 é expresso na 
superfície celular e reconhece flagelina, uma proteína motora expressa por bactérias; e o TLR9 também encontra-se ancorado às membranas endossomais e reconhece motivos de CpG DNA não-metilados, expresso por bactérias (Pivarcsi, Nagy, Kemeny, 2005; Pastore et al., 2006).

Os TLR 1, 2, 4, 5 e 6 se ligam à proteína adaptadora MyD88, a qual desencadeia uma cascata de ativação que resulta na fosforilação e ativação do fator de transcrição Fator NuclearKappa B (NF- $\kappa$ B) ou da Proteína Ativadora 1 (AP-1) que se ligam na região promotora de genes que codificam citocinas próinflamatórias como interleucina (IL) -1 $\beta$, IL-6, IL-8, IL-17C, IL23, Fator de Necrose Tumoral (TNF) e Fator Estimulador de Colônia Macrófago-Granulócito (GM-CSF). Os TLR 3 e 9 se ligam à proteína adaptadora Domínio-TIR-Contendo-AdaptadorInduzindo-Interferon- $\beta$ (TRIF) que fosforila e ativa o fator de transcrição Fator Regulatório de Interferons (IRF), responsável pela transcrição de genes que codificam interferons do tipo I que promovem a resposta antiviral (Pivarcsi, Nagy, Kemeny, 2005; Pastore et al., 2006).

Além do reconhecimento de microorganismos via PRRs, os queratinócitos também são capazes de interagir com o microambiente celular ao expressar diversos receptores para citocinas como IL-4, IL-6, TNF e GM-CSF, sendo o receptor de IL-17A de muita importância no contexto inflamatório. O receptor de IL-17A é um heterodímero formado pelas combinações das subunidades IL-17RA, IL-17RC e IL-17RD. Os queratinócitos expressam os heterodímeros IL-17RA/IL-17RC ou IL-17RA/IL-17RD. A ligação da IL-17A com o heterodímero IL17RA/IL-17RC recruta e ativa o complexo ACT1, TRAF6 e CARMA2 que resulta na ativação de NF- $\kappa$ B e o próprio IL-17RA interage com o Receptor de Fator de Crescimento Epidermal (EGFR) o transativando. A ligação da IL-17A com o heterodímero IL-17RA/IL-17RD ativa MAPK p38 e JNK e a subunidade IL-17RD também interage com o Receptor de Fator de Crescimento de Fibroblasto 2, o transativando. Em ambos os casos, a ligação de IL-17A ativa o Transdutor de Sinal e Ativador de Transcrição 3 (STAT3) que induz proliferação e maturação, resultando na expressão de queratinas específicas de queratinócitos nesse estado de ativação e proliferação, as queratinas 6, 14, 16 e 17 (K6, K14, K16 e K17) (Freedberg et al., 2001; Bernard et al., 2012; Albanesi et al., 2018).

Acredita-se que os queratinócitos possam mediar a fagocitose de microorganismos, sabe-se de sua capacidade em produzir espécies reativas de oxigênio e nitrogênio liberados em fagossomas e que o IFN- $\gamma$ é capaz de induzir a expressão de proteínas do Complexo de Histocompatibilidade Principal de Classe II (MHC-II) em cultura primária e de linhagem de queratinócitos humanos atribuindo função de apresentadora de antígeno não profissional à estas células. A expressão de PRR pelos queratinócitos e sua possível atividade como apresentadora de antígeno os confere o papel de sentinelas, sendo as primeiras células em contato com o 
antígeno na pele, produzem citocinas que atuam de maneira autócrina, induzindo sua própria ativação e endócrina, recrutando e ativando células do sistema imune no local iniciando assim um processo inflamatório (Pivarcsi et al., 2003; Pastore et al., 2006).

\subsubsection{Células Dendríticas}

As células de Langerhans (LC) são um tipo especializado de células dendríticas assim chamadas por expressarem langerina, uma proteína que forma complexos em forma de raquete em seu citoplasma, os grânulos de Birbeck. São encontradas apenas na epiderme e sua origem ocorre no saco vitelino e fígado fetal se renovando durante a vida a partir de progenitores na própria epiderme. Como descrito anteriormente, a resposta imune induzida na epiderme tende a ser tolerogênica a fim de manter microorganismos em relação comensal e não reagir à antígenos que não ofereçam perigo, são justamente essas células as responsáveis por esta resposta. Embora as LC, assim como os queratinócitos, também reconheçam antígenos que transpassem a barreira epidérmica, quando comprometida, sua resposta é iniciada pela produção

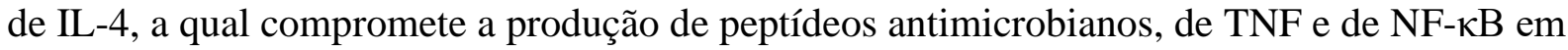
queratinócitos. Pelo fato da IL-4 estar relacionada à respostas alérgicas de caráter $\mathrm{T}_{\mathrm{H}} 2$ acreditava-se que essas células seriam importantes em reações alérgicas da pele, no entanto, estudos nos quais as LC foram depletadas e modelos de hipersensibilidade foram induzidos em camundongos, a ausência de LC resultou em piora do quadro inflamatório, atribuindo de forma definitiva à estas uma função anti-inflamatória (Nestle et al., 2009; Ogawa Y et al 2018; Macri et al., 2018).

As DC de origem hematopoiéticas podem se diferenciar em DC clássicas e DC plasmocitóides (pDC). Na pele as DC clássicas são conhecidas como apresentadoras de antígeno profissionais (APC), se encontram na derme e são chamas de DC dermais (dDC). As dDC são pró-inflamatórias, uma vez ativadas, seja pelo reconhecimento do antígeno ou por citocinas produzidas por queratinócitos, LC ou mesmo pelas pDC, essas células migram para linfonodos drenantes onde apresentam o antígeno via MHC-II à linfócitos e através da produção de citocinas IL-12 e/ou IL-6, induz a diferenciação destes linfócitos em perfis produtores de IFN- $\gamma$ e/ou IL-17. As pDC não migram, mas expressam TLR 7, 8 e 9 que induzem produção de interferons do tipo I, IFN- $\alpha$ e IFN- $\beta$ quando ativados (Nestle et al., 2009; Sumpter et al., 2019; Macri et al., 2018).

\subsubsection{Macrófagos}

$\mathrm{Na}$ pele existem populações de macrófagos residentes provenientes do fígado fetal e migratórios, cuja origem é hematopoiética. Os macrófagos residentes atuam como sentinelas na pele e podem ser modulados por células dendríticas e/ou alarminas a fagocitarem antígenos 
e migrarem para linfonodos drenantes onde atuam como apresentadores de antígenos, atuam depuração de células mortas e debris celulares, tanto derivados de condições homeostáticas quando resultantes de um processo inflamatório infeccioso, produzem fatores que induzem angiogênese e também produzem fatores estimulantes de fibroblastos, resultando na produção de elementos da matriz extracelular colágeno e fibronectina que, por sua vez, são fundamentais no remodelamento e reparo tecidual (Wynn, Chawla, Pollard, 2013).

Quando modulados por pDCs e dDCs, os macrófagos se polarizam para um perfil inflamatório chamados M1 que na pele são importante fonte de IL-23, a qual mantém a população de células produtoras de IL-17. Os macrófagos produzem ainda IL-1 $\beta$, TNF, IL-6 e CXCL8, os dois primeiros ativam o endotélio vascular para permitir a diapedese de células recrutadas, são pirógenos e aumentam a drenagem linfática para os linfonodos favorecendo a chegada de APCs; a IL-16 ativa linfócitos e o CXCL-8 é quimioatraente de neutrófilos. Nos linfonodos drenantes estes macrófagos polarizam e recrutam a resposta imune adaptativa dos perfis $\mathrm{T}_{\mathrm{H}} 1$ e $\mathrm{T}_{\mathrm{H}} 17$. Quando modulados por células de Langerhans por meio da produção de IL4, os macrófagos se polarizam para um perfil anti-inflamatório, chamados de M2, os quais realizam o clearance, ativam a cascata de coagulação e atuam no remodelamento e reparo tecidual. Nos linfonodos drenantes polarizam e recrutam a resposta imune adaptativa do perfil TH2 (Gordon, Pluddemann, 2017; Orecchioni et al., 2019).

\subsubsection{Neutrófilos}

Os neutrófilos são granulócitos de origem hematopoiética e não são encontrados nos tecidos em condições de homeostase, mas são as primeiras células a serem recrutadas em condições inflamatórias pelos queratinócitos, células dendríticas e macrófagos residentes através da produção de IL-8, alarminas da família S100, dentre outros. Os neutrófilos são células fagocíticas que na presença de IL-17 produzem explosão respiratória, na qual espécies reativas de oxigênio e nitrogênio são liberadas no microorganismo e podem ainda degranular liberando lisozimas, colagenases e elastases, enzimas nocivas aos microorganismos, além de mediadores inflamatórios como prostaglandinas, leucotrienos e fator ativador de plaquetas auxiliando na modulação do fluxo sanguíneo para o local da inflamação (Mann et al., 2012; Nestle et al., 2009). Além disso os neutrófilos são capazes de produzir armadilhas extracelulares de neutrófilos (NETs) por meio de NETose em que a célula morre liberando todo o conteúdo de seus núcleos e grânulos, eliminando e/ou prendendo os microorganismos os deixando mais susceptíveis a fagocitose, ou por NETose não lítica na qual o núcleo e os grânulos são liberados mas a célula permanece viva (Papayannopoulos, 2018).

\subsubsection{Mastócitos}


Os mastócitos são originados na medula óssea e maturam nos tecidos onde se tornam residentes respondem e produzem IL-4 quando ativadas, degranulam liberando histamina, uma substância vasodilatadora; prostaglandinas, que atuam tanto como vasodilatadoras quanto em nociceptores induzindo a imobilização do local inflamado; e aminas vasoativas, como bradiquinina que induz vasodilatação, leucotrienos que induzem vasoconstrição aumentando o espaço entre as células endoteliais favorecendo a diapedese de leucócitos e proteases que clivam debris celulares produzindo mais mediadores lipídicos da inflamação (prostaglandinas e leucotrienos). Os mastócitos podem ainda se ligarem à porção FC de IgE atuando assim em reações de hipersensibilidade do tipo I, as alergias (Siebenhaar et al., 2017; Sumpter et al., 2019).

\subsubsection{Linfócitos}

A pele conta com diferentes populações de linfócitos, em condições de homeostase a maioria são células de memória e expressam o antígeno associado a linfócitos (CLA), o qual acredita-se ser induzido após o contato com células dendríticas derivadas da pele, processo denominado de imprinting, em que a expressão de CLA é marcador de células de memória da pele. A clivagem de vitamina D por raios ultravioletas (UV) seria importante para induzir expressão de CCR10, necessário para o homing, ou seja, para migração destas células de volta para pele (Nestle et al., 2009).

Os linfócitos mais predominantes na epiderme em condições de homeostase são as células T CD8+ de memória, também chamadas de citotóxicas por induzirem a morte de células infectadas através da liberação de perforinas, que abrem poros na membrana celular e granzimas, que ativam caspases resultando na apoptose celular. Este processo deve ser induzido por apresentação cruzada do antígeno por células dendríticas ou por meio de IL-2 produzido por células T CD4+ auxiliares. As células T CD8+ são importante fonte de IFN- $\gamma$, o qual atua de maneira autócrina, ativando-as, e parácrina, ativando macrófagos aumentando sua capacidade microbicida e induzindo explosão respiratória, além de ativar células assassinas naturais (Nestle et al., 2009, Di Meglio P, Perera GK, Nestle FO, 2011; Kabashima et al., 2019).

As células T CD4+ ou auxiliares é composta por diferentes subpopulações celulares que desempenham funções imunológicas distintas. Na pele, a subpopulação de células T CD4+ mais abundante é a de células $\mathrm{T}$ reguladoras (Treg), estas são diferenciadas quando reconhecem autoantígenos com certa afinidade falhando na seleção negativa durante o processo de tolerância central no timo, ou ainda, são induzidas nos linfonodos drenantes por IL-4 e TGF- $\beta$. As Treg atuam na tolerância deste órgão impedindo respostas inflamatórias a microorganismos comensais ou não patogênicos por meio de liberação de IL-10, TGF- $\beta$, expressão de CTLA-4 
e PD-1, que modulam a atividade de macrófagos e células dendríticas induzindo a resposta para perfis anti-inflamatórios ou mesmo induzindo a anergia de células T efetoras. Além disso, as Treg expressam a cadeia $\alpha$ do receptor da IL-2, que possui alta afinidade à citocina que, por consequência, depriva outros linfócitos auxiliares da ativação via IL-2, processo necessário para sobrevivência destes. Desta forma, as Treg são responsáveis por regular a resposta imune mantendo a tolerância na pele e também minimizando os danos teciduais causados durante um processo inflamatório intenso ou crônico (Nestle et al., 2009, Di Meglio P, Perera GK, Nestle FO, 2011; Kabashima et al., 2019).

As células $\mathrm{T}_{\mathrm{H}} 1$ atuam em resposta a microorganismos intracelulares tais como vírus, protozoários e micobactérias, mas atuam também em autoimunidade e em doenças imunomediadas. As células $\mathrm{T}_{\mathrm{H}} 1$ são induzidas por IL-12 produzida por células apresentadoras de antígeno nos linfonodos drenantes e são fonte de IL-2 e IFN- $\gamma$. A IL-2 é crucial para a sobrevivência de linfócitos T enquanto o IFN- $\gamma$ ativa fagócitos, linfócitos T CD8+ e células assassinas naturais. As células $\mathrm{T}_{\mathrm{H}} 2$ são induzidas nos linfonodos drenantes quando na presença de IL-4 produzida por APCs e na ausência de estímulos capazes de induzir as demais subpopulações. Essas células atuam na manutenção da homeostasia da pele e são importantes em doenças alérgicas e em infecções helmínticas nas quais atua em conjunto com mastócitos e induzem ainda células B a produzirem e secretarem IgE. Assim como as células $\mathrm{T}_{\mathrm{H}} 1$ e $\mathrm{T}_{\mathrm{H}} 2$ as células $\mathrm{T}_{\mathrm{H}} 17$ são induzidas nos linfonodos drenantes por APCs, mas na presença de IL-6 e TGF$\beta$ produzidas por estas. As células $T_{H} 17$ são principais fonte de IL-17A que ativa queratinócitos, neutrófilos e macrófagos potencializando a atividade microbicida dessas células contra agentes extracelulares ou intracelulares quando no espaço extracelular tais como bactérias, fungos e protozoários, recrutam e ativam neutrófilos no local da inflamação sendo então importantes em doenças autoimunes e imunomediadas, nas quais participam na indução de lesões teciduais (Luckheeram et al., 2012; Saravia, Chapman, Chi, 2019).

\subsubsection{Linfócitos Não-Convencionais}

As células $\mathrm{T} \gamma \delta$ e assassinas naturais são os principais linfócitos não-convencionais na pele. As subpopulação de células T $\gamma \delta$ é tida como uma importante fonte de IL-17 que, conforme abordado anteriormente participa dos processos inflamatórios e contribuem para ativação de queratinócitos, quimiotaxia e ativação de neutrófilos e para remodelação tecidual por meio da liberação de fatores de crescimento do tecido conectivo (CTGF), fator de crescimento de fibroblasto 9 (FGF9), fator de crescimento de queratinócitos (KGF) e fator de crescimento semelhante a insulina 1 (IGF1) (Vantourout, Hayday, 2013; Zarin et al., 2015). Já as células assassinas naturais atuam em resposta a pDCs principalmente contra antígenos virais e são 
capazes de induzir citotoxidade celular por meio da liberação de granzimas e perforinas em um mecanismo semelhante ao de células T CD8+ quando ativadas por IFN- $\gamma$ liberado por células $\mathrm{T}_{\mathrm{H}} 1$ e T CD8+, no entanto, essa citotoxicidade se baseia na ausência de expressão de MHC-I ou na presença de antígeno não próprio no complexo MHC-I (Bjorkstrom et al., 2016).

\subsection{Psoríase}

\subsubsection{Aspectos Gerais}

A psoríase é uma doença imunomediada crônica que acomete principalmente a pele. Essa desordem atinge entre 1,5 a 3\% da população mundial, sendo mais comum em países desenvolvidos. Apesar de atingir ambos os sexos, homens tendem a desenvolver formas mais graves, sua incidência em indivíduos caucasianos é maior, entre 4,6 e 4,7\% enquanto em afrodescendentes é em torno de 0,4 a 0,7\%. A doença se manifesta principalmente no verão, de maneira que o índice de radiação ultravioleta (UV) é utilizado como auxiliar no diagnóstico, já que os sinais clínicos apresentam piora no inverno (Griffiths et al., 2017, WHO, 2017). No Brasil a prevalência é em torno de $1 \%$ da população, mas essa proporção pode dobrar na região sul do país (Duarte, Porto-Silva, Oliveira 2015; Romiti et al., 2017).

Acredita-se que a psoríase seja capaz de induzir distúrbios psicológicos como ansiedade, depressão e suicídio devido a estigmatização da doença o que leva os indivíduos a se isolarem. Prejuízos econômicos e a elevada produção de citocinas próinflamatórias em caráter crônico afetam de maneira significativa a qualidade de vida dos pacientes (Rigas et al., 2019). A psoríase possui ainda características de autoimunidade comuns com doença de Crohn, esclerose múltipla e artrite reumatoide, mas não se sabe qual antígeno próprio é responsável por induzir a imunopatologia observada o que desafia o desenvolvimento de novos meios de diagnóstico e de tratamento que não repercutam efeitos indesejados (Perera, Di Meglio, Nestle, 2012; Rosenblum, Remedios, Abbas, 2015).

Clinicamente a psoríase pode se manifestar na pele, ou acometer outros tecidos, como as articulações. A manifestação cutânea pode se apresentar como psoríase vulgar, gutata, inversa, palmo-plantar, postulosa e eritrodérmica. A psoríase vulgar é descrita em cerca de $90 \%$ dos casos da doença, sendo assim o fenótipo mais comum no qual são observadas placas eritematosas acinzentadas bem delineadas e localizadas principalmente nas áreas de extensão, cotovelos, joelhos e couro cabeludo, mas tais placas podem ser observadas em qualquer parte do corpo, provocam prurido, descamam e podem doer. A psoríase gutata se difere da vulgar por apresentar lesões em forma de pequenas gotas delimitadas. Na psoríase inversa as lesões são úmidas e não descamam, acometem regiões de articulações onde a pele se dobra como nas axilas, virilhas e inframamária (Boehncke, Schon, 2015; Scher et al., 2019). 
A psoríase pustular ou postulosa pode ser localizada ou generalizada, é muito comum em pacientes com histórico de infecções bacterianas e outras formas de psoríase e em crianças, as lesões se caracterizam como vesículas purulentas não infecciosas e podem acometer palmas e plantas (Figura 2D, E e F) e pode se agravar tornando-se generalizada (Figura 2G). Em cerca de $5 \%$ dos casos os fenótipos descritos acima podem se disseminar por todo o corpo caracterizando assim a psoríase eritrodérmica ou disseminada, que pode acarretar infecções secundárias e ser letal (Figura 2H). Concomitantemente a manifestações cutâneas, em cerca de $30 \%$ dos indivíduos com psoríase cutânea ocorre desenvolvimento de artrite psoriática, uma forma clínica distinta (Boehncke, Schon, 2015; Scher et al., 2019).
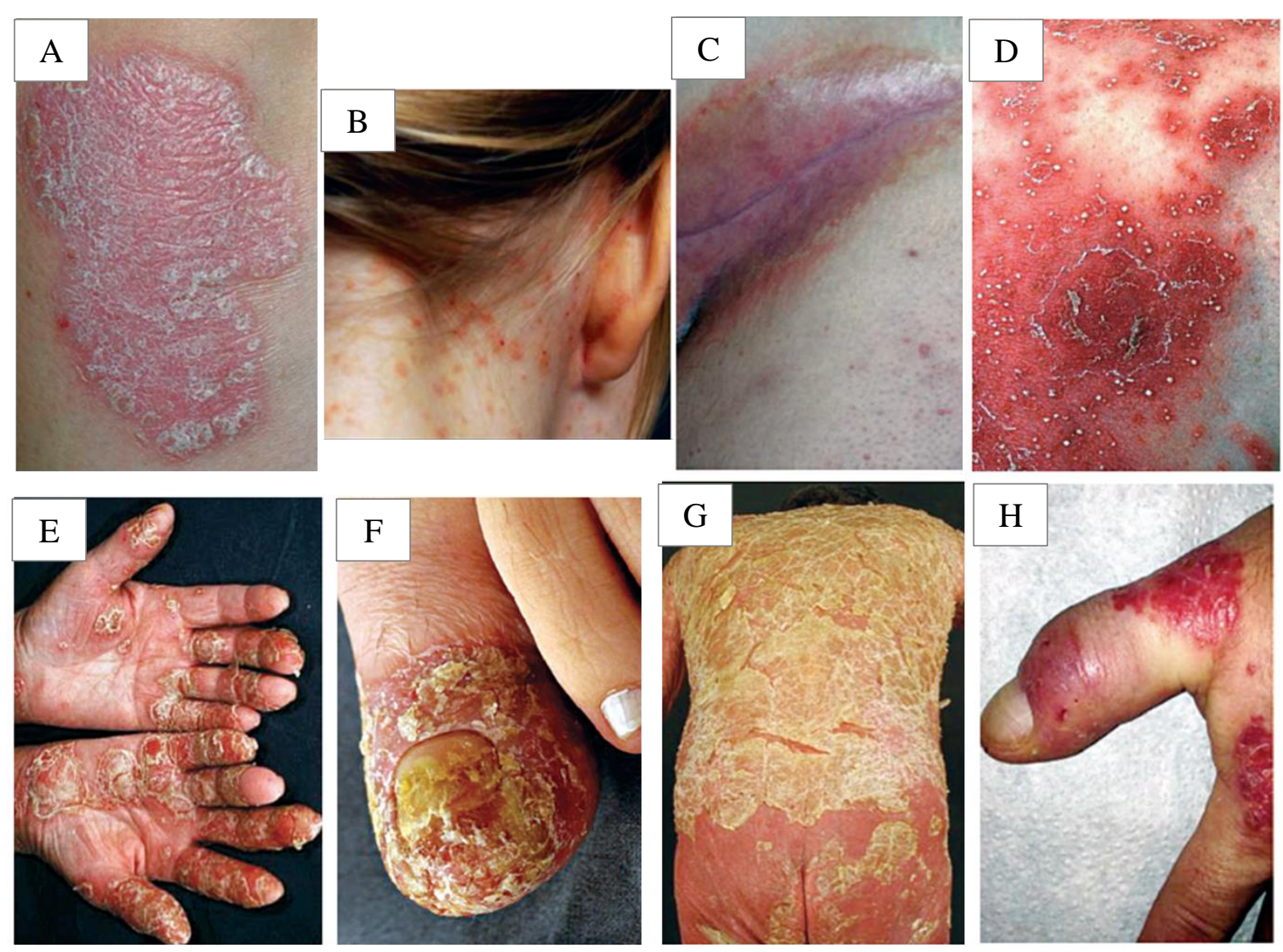

Figura 2. Manifestações clínicas da psoríase. Ilustração representativa de pacientes com lesões eritematosas acinzentadas em psoríase vulgar (A); na psoríase gutata lesões menores e dispersas $(\mathbf{B})$, psoríase inversa nas axilas $(\mathbf{C})$, na psoríase pustular observa-se eritema e pústulas (D), nas palmas $(\mathbf{E})$ e nos pés $(\mathbf{F})$, a forma mais grave, disseminada da doença, a psoríase eritematosa $(\mathbf{G}) ; 30 \%$ de todas as formas podem se desenvolver em artrite psoriática sozinha ou acompanhada de outras manifestações $(\mathbf{H})$. Adaptado de Boehncke et al 2015.

\subsubsection{Fatores Predisponentes}

Atualmente 12 loci associados a susceptibilidade para psoríase são conhecidos e denominados PSORS. O lócus PSORS1 é o de maior associação, sendo localizado na região do 
HLA, que decodifica o MHC humano, o alelo HLACw6 está presente entre 60 a $65 \%$ dos indivíduos com psoríase, mas em apenas $15 \%$ dos controles saudáveis. Os loci relacionados as

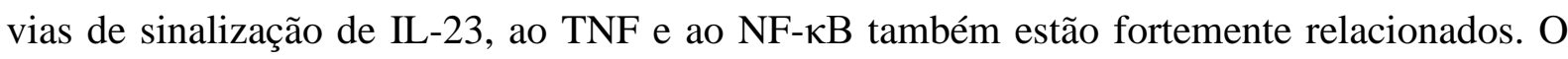
lócus PSORS4 inclui genes altamente expressos na psoríase como as proteínas da família S100 e genes com expressão reduzida, como loricrin e filagrina. Deleções em LCE3B e LCE3C foram identificados como fatores de risco para psoríase enquanto mutações que conferem ganho de funções ao IL-36RN e ao CARD14 foram identificados como fatores que predispõem diferentes formas de psoríase (Wagner et al., 2010; Boehncke, Schon, 2015).

Os fatores ambientais envolvidos no desenvolvimento de psoríase são diversos e variam de traumas e injúrias como pancada ou feridas, queimaduras de sol, até substâncias químicas. Medicamentos de uso crônico como os utilizados no tratamento de malária, $\beta$-bloqueadores, lítio e anti-inflamatórios não esteroidais, qualquer fator que interfira na homeostase da pele pode desencadear a doença. Infecções bacterianas por Staphylococcus aureus na pele e Streptococcus são descritas como predisponentes de psoríase gutata e acredita-se que infecção por HIV predispõem, além de dificultar o tratamento da doença (Wagner et al., 2010; Boehncke, Schon, 2015).

\subsubsection{Imunopatologia}

Situações de estresse para pele resultantes de um ou da associação de vários fatores que causam morte de queratinócitos e liberação de DNA próprio por essas células, os nucleotídeos liberados formam complexos com a catelicidina LL-37 liberadas por queratinócitos ativados pelo estresse, esses complexos são reconhecidos por TLR-9 de pDC, ativando-as. As pDC produzem interferons do tipo I e TNF- $\alpha$ o que reforça a ativação de queratinócitos e ativa dDC, estas últimas são migratórias e seguem para os linfonodos drenantes iniciando a resposta imune adaptativa polarizada para linfócitos $\mathrm{T}_{\mathrm{H}} 1, \mathrm{~T}_{\mathrm{H}} 17$ e $\mathrm{T} \gamma \delta$. Na pele, o TNF produzido e liberado por queratinócitos e pDC mantém o estado de ativação destas células, induz aumento na permeabilidade e fluxo sanguíneo para o local da inflamação e ativa as células endoteliais vasculares a expressarem integrinas e selectinas permitindo a migração e diapedese de leucócitos para o local (Figura 3) (Nestle et al., 2009; Lowes, Suarez-Farinas, Krueger, 2014; Mahil, Capon, Baker, 2016).

Os queratinócitos ativados produzem TNF, catelicidinas, defensinas e quimioatraentes de neutrófilos como alarminas da família S100, IL-8, CXCL-1, CXCL-3 e CXCL-5, desta forma acumula-se infiltrado neutrofílico na pele (Furue, Furue, Nakahara, 2020). Apesar de abundante nas lesões, o papel do neutrófilo na psoríase é pouco descrito e não se sabe ao certo de que maneira atua na doença, mas acredita-se que participe da indução das lesões através de 
degranulação e/ou formação de NETs. Os queratinócitos produzem ainda IL-6 e IL-23, que atuam na manutenção da população de células $\mathrm{T}_{\mathrm{H}} 17$, IL-1 $\beta$, que ativa macrófagos e TGF- $\beta$, atuando no remodelamento tecidual promovendo a proliferação de queratinócitos e fibroblastos. Em associação essas citocinas induzem a liberação de fator de crescimento de queratinócitos e TGF- $\beta$ por fibroblastos contribuindo para a proliferação desenfreada dos queratinócitos (Nestle et al., 2009; Lowes, Suarez-Farinas, Krueger, 2014; Mahil, Capon, Baker, 2016).

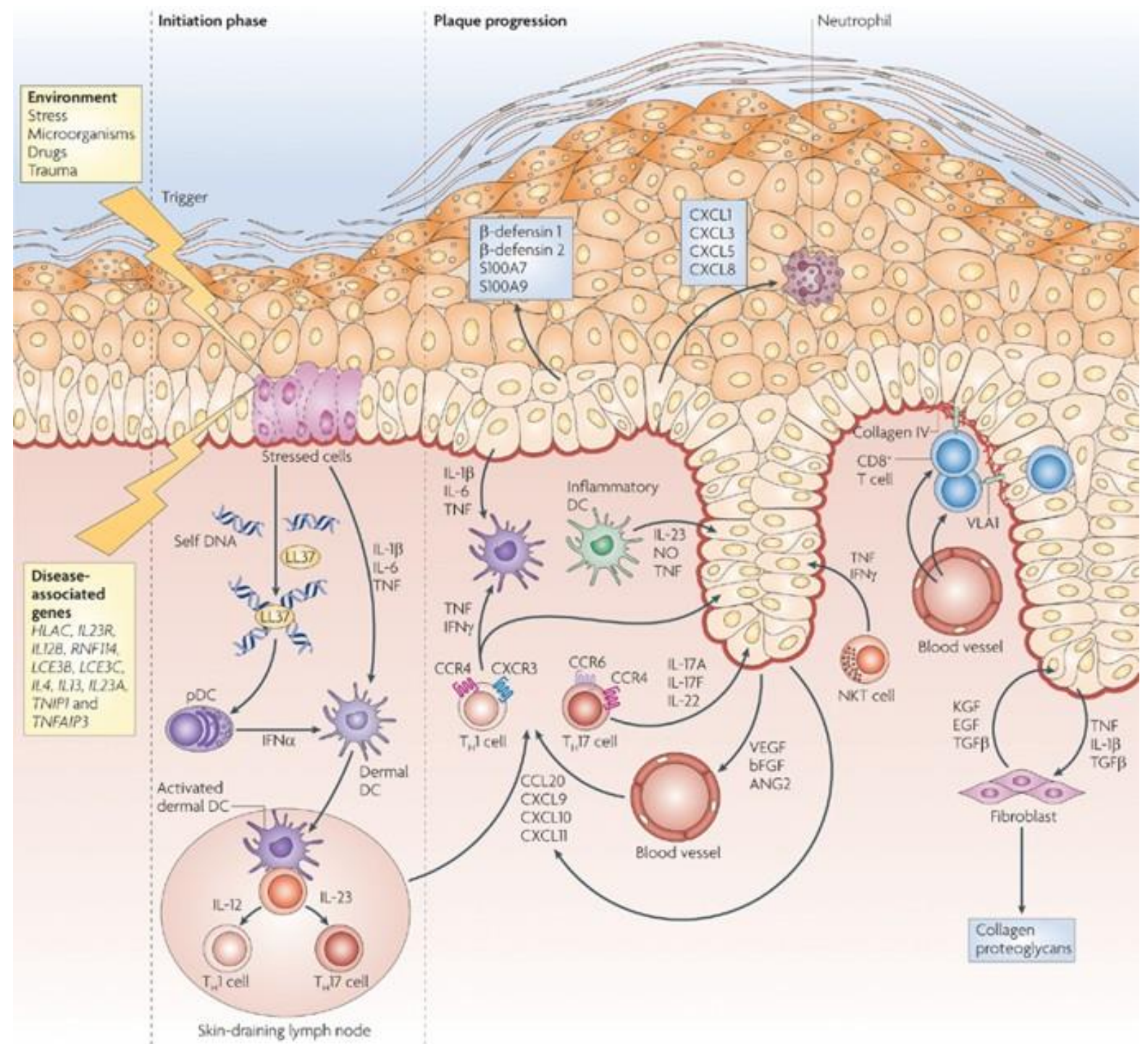

Nature Reviews | Immunology

Figura 3. Imunopatologia da psoríase. Fatores estressantes resultam na liberação de nucleotídeos e LL-37 por queratinócitos, estes se complexam e ativam pDCs, que por sua vez ativam $\mathrm{dDCs}$, que migram para linfonodos drenantes iniciando a resposta imune adaptativa por células $T_{H} 1$ e $T_{H} 17$, estas migram para pele onde iniciam a secreção de citocinas como IL-17 que ativam queratinócitos e em conjunto recrutam e ativam neutrófilos, macrófagos, células $\mathrm{T}$ CD8+, assassinas naturais e fibroblastos. Adaptado de Nestle et al 2009. 
Os linfócitos $\mathrm{T}_{\mathrm{H}} 1$ produzem IFN- $\gamma$ que atua nas diferentes populações de células dendríticas, macrófagos, linfócitos $\mathrm{T}$ citotóxicos residentes e células assassinas naturais. As células $\mathrm{T}_{\mathrm{H}} 17$ e $\mathrm{T} \gamma \delta$ produzem IL-17 que atua em queratinócitos em conjunto com TNF ativando-os e induzindo a sua proliferação, mas impedindo maturação, como resultado disto, observa-se aumento irregular no estrato basal e espinhoso da epiderme, denominado hiperqueratose, observa-se corneócitos nucleados no estrato córneo, denominado paraqueratose e ainda, projeções papilares da epiderme para derme, denominado acantose, caracterizando assim as lesões observadas na psoríase. Nesta condição, o turnover que levaria 28 dias para completar o ciclo, leva entre 4 e 7 dias (Nestle et al., 2009; Bata-Csorgo, Szell, 2014; Lowes, Suarez-Farinas, Krueger, 2014; Mahil, Capon, Baker, 2016).

\subsubsection{Diagnóstico}

O diagnóstico de psoríase é predominantemente clínico, de acordo com a característica das lesões, a época do ano em que se manifestam e o histórico do paciente. Biópsia pode ser realizada para auxiliar no diagnóstico, a presença de acantose, hiperqueratose e paraqueratose, bem como de infiltrado inflamatório e neovascularização são indicativos quando associados ao exame clínico, no entanto, a ausência de marcadores específicos para a doença é um grande empecilho uma vez que esta pode ser facilmente confundida com outras dermatoses como dermatite atópica, alérgica, de contato, tinea capitis, tinea corporis (ou tinha do corpo) e dermatite seborreica (Boehncke, Schon, 2015).

\subsubsection{Tratamento}

A psoríase não tem cura, o tratamento é tópico em pacientes com formas cutâneas localizadas da doença o que corresponde a $80 \%$ dos casos e sistêmico para formas mais graves. Tratamentos tópicos com corticoesteróides,, análogos de vitamina D, inibidores de calcineurina como tacrolimus e pimecrolimus são utilizados no tratamento de formas cutâneas restritas, sendo que os últimos dois são utilizados para tratamento de manifestações no couro cabeludo e áreas de difícil acesso. Para casos mais graves pode-se utilizar fototerapia ou fotoquimioterapia, porém, ambas apresentam potencial carcinogênico e para o tratamento de uma doença crônica e reincidente como psoríase, seu uso é limitado (Gottlieb, 2005; Boehncke, Schon, 2015; Duarte, Porto-Silva, Oliveira 2015).

As principais drogas de uso sistêmico convencional são o metotrexato, acitretina e ciclosporiana. Mais recentemente imunobiológicos como anticorpos monoclonais contra mediadores altamente produzidos na doença como inibidores do TNF (infliximabe, adalimumabe e etanercept) e das interleucinas (IL-23/IL-12; IL-17 e IL-23): ustekinumab (antip40 IL-12/IL-23), secukinumab (anti-IL-17), rizanquizumabe e gluselcumade (anti-IL-23) são 
altamente promissores (Gottlieb, 2005; Mahil, Capon, Baker, 2016). O grande problema do tratamento sistêmico com essas drogas é que não possuem alvo específico e afetam todo o sistema imune do indivíduo o deixando susceptível ao desenvolvimento de infecções nos trato respiratório, geniturinário e gastrointestinal, regiões mais vulneráveis do corpo por estarem em contato constante com microorganismos externos, enfatizando assim a necessidade de um alvo terapêutico que seja muito expresso nas lesões de psoríase, mas não esteja presente na pele saudável, em condições de homeostase.

\subsection{Imunometabolismo}

O papel de processos metabólicos na função de células imunológicas começou a ser investigado há trinta anos, estudos iniciais focaram na produção energética e biossíntese considerando a demanda de macrófagos e células T ativados. Nesse sentido o mecanismo alvo de rapamicina (mTOR) se tornou central para o desenvolvimento do imunometabolismo visto que promove transdução de mRNA, síntese lipídica e é sensor de aminoácidos e fatores de crescimento, componentes essenciais para a diferenciação de células $\mathrm{T}$ e de monócitos. Por conseguinte, a AMP quinase envolvida na promoção do catabolismo inibindo assim o mTOR ganhou destaque uma vez sua ação implica na limitação da ativação das células imunes (O’Neill, Kishton, Rathmell, 2016; Wang, Luan, Medzhitov, 2019).

Atualmente, sabe-se do envolvimento de diferentes vias metabólicas em atividades de células imunes e em seus estágios de ativação, pois cada um requer tanto níveis de energia quanto metabólitos distintos. Com mais destaque e de maior importância para este trabalho, a via do ácido cítrico, tricarboxílico ou ciclo de Krebs acontece na mitocôndria de células em repouso para produção de adenosina trifosfato (ATP), energia, a partir de acetil coenzima A (acetil-CoA). Em situações de estresse oxidativo ou mesmo quando a célula se torna biologicamente ativa como em processos inflamatórios, a demanda por energia se eleva de maneira que a glicólise se torna a principal fonte de energia. Essa polarização resulta no acúmulo de diversos metabólitos, dentre eles o succinato (Kominsky, Campbell, Colgan, 2010; O’Neill, Kishton, Rathmell, 2016; Puleston, Villa, Pearce, 2017; Wang, Luan, Medzhitov, 2019).

\subsection{O Succinato e Seu Receptor SUCNR1}

O succinato é um ácido dicarboxílico intermediário do ciclo de Krebs que em condições de estresse diversas enzimas são inativadas, interrompendo o ciclo. Nessas condições o $\alpha$ cetoglutarato continua sendo gerado por transaminação, sua conversão em succinato ocorre por descarboxilação não enzimática, além disso, a enzima succinato desidrogenase começa a atuar de forma reversa, catalisando fumarato em succinato, reação esta que é alimentada pelo ciclo 
de nucleotídeos de purina (Figura 4). Em conjunto essas reações resultam em acúmulo de succinato na mitocôndria e uma vez acumulado o succinato é transportado para o citosol por transportadores dicarboxílicos, e do citosol para o espaço extracelular por canais proteicos, já na corrente sanguínea o succinato é transportado pela proteína INDY (do inglês I'm not dead yet) associada a longevidade (Tretter, Patocs, Chinopoulos, 2016; Fonseca et al., 2016; Grimolizzi, Arranz, 2018).

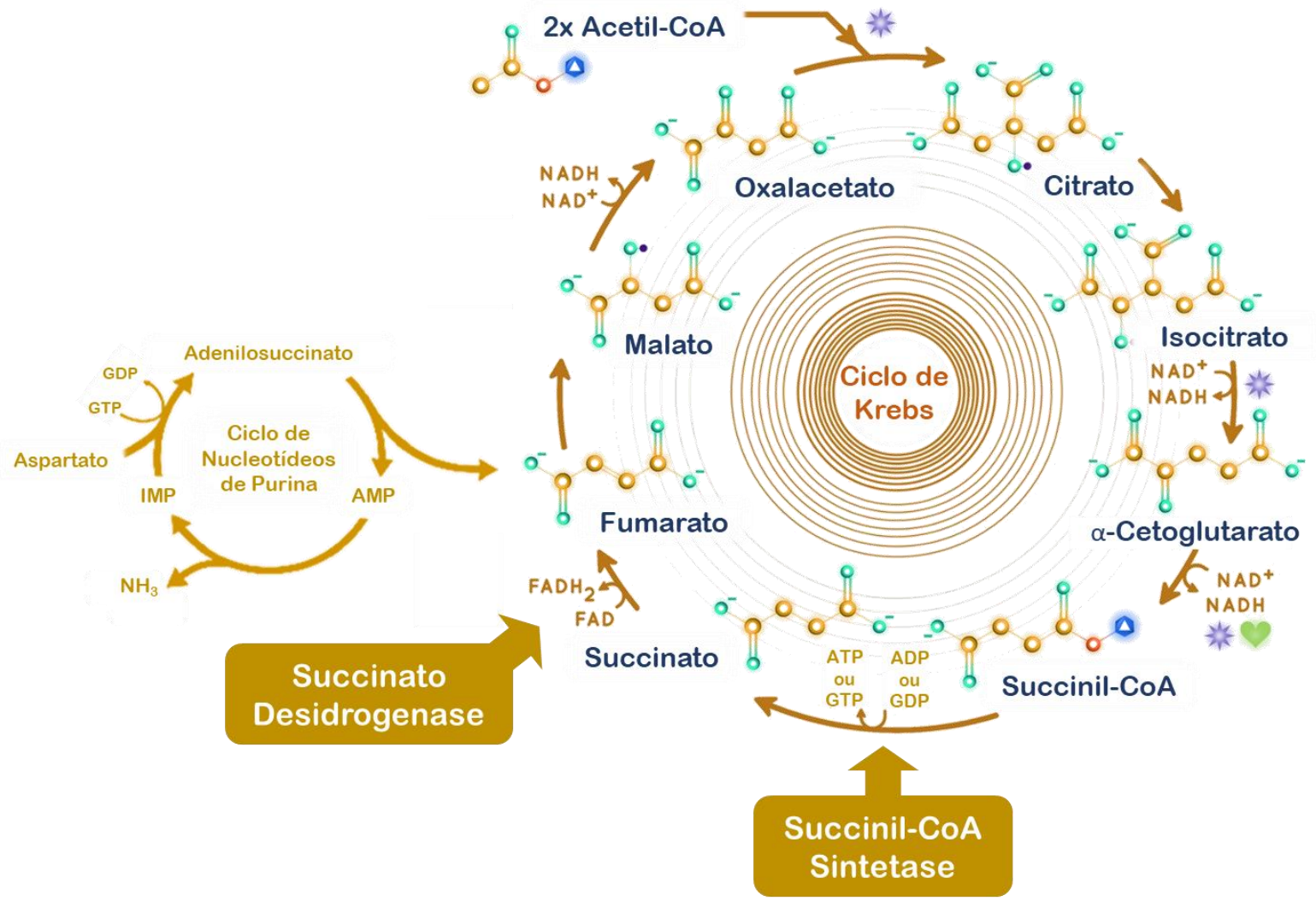

Figura 4. O ciclo de Krebs. Em condições de homeostasia o succinato é produzido a partir do catabolismo enzimático de succinil-CoA e reduzido em fumarato pela succinato desidrogenase. Em condições de estresse o metabólito se acumula por conversão direta de $\alpha$-cetoglutarato e ação reversa da succinil desidrogenase. Adaptado de Fonseca et al 2016.

Com seu papel bem descrito na respiração aeróbica desde a década de 1930, Krebs observou acúmulo de succinato no espaço intersticial diante de isquemia e posteriormente observou-se que a infusão de succinato via intravenosa aumenta a pressão sanguínea de camundongos. Mais tarde, descobriu-se ainda que o acúmulo de succinato favorece a succinilação, um processo no qual proteínas envolvidas no metabolismo celular passam por modificações pós-translacionais a fim de se aumentar atividades enzimáticas envolvidas no metabolismo de glucose e de lipídio para atender a demanda por ATP. Diversos estudos atribuíram funções para o succinato independente do ciclo de Krebs e que poderiam ocorrer no 
meio extracelular (Tretter, Patocs, Chinopoulos, 2016; Fonseca et al., 2016; Grimolizzi, Arranz, 2018).

Em 2004, o receptor acoplado a proteína G (GPCR) 91 (GPR91), uma serpentina transmembrana até então considerado receptor órfão, foi descoberto como receptor do succinato, tendo este como ligante específico e por ser o primeiro e único receptor de succinato descrito é alternativamente denominado receptor de succinato 1 (SUCNR1). Dentre os 800 compostos testados, dos quais 200 são estruturalmente relacionados ao succinato, apenas maleato e oxalacetato foram capazes de ativar o SUCNR1, no entanto com 5 a 10 vezes menos eficácia que o succinato. Assim como os demais GPCRs, demonstrou-se ainda que o SUCNR1 é dessensibilizado e sequestrado após sua ativação para evitar sinalização prolongada. Em associação estes fatos sugerem o succinato e o SUCNR1 interessantes alvos terapêuticos (He et al., 2004; Gilissen et al., 2016).

A partir da descoberta do SUCNR1, diversos trabalhos demonstraram sua expressão em células de diversos tecidos e desvendaram atividades do succinato através da sinalização de seu receptor. Na mácula densa dos glomérulos renais, onde o SUCNR1 é mais expresso em todo o organismo, sua sinalização induz liberação de cálcio e inibe a produção de cAMP resultando na liberação de renina e aumento da pressão sanguínea (Vargas et al., 2009); nos cardiomiócitos induz aumento na expressão de genes hipertróficos resultando em hipertrofia no miocárdio (Aguiar et al., 2014); no fígado atua em sinergia com fatores de crescimento e hormônios na ativação de hepatócitos (Cho, 2018); no tecido adiposo inibe a lipólise dos adipócitos contribuindo para o ganho de peso em modelos de obesidade (McCreath et al., 2015); na retina induz angiogênese retinal e considerando o acúmulo de succinato no humor vítreo de pacientes com retinopatia decorrente de diabetes do tipo II, sugere sua participação na patologia da diabetes (Sapieha et al., 2008); o que associado ao acúmulo de succinato nos rins de camundongos em modelo de diabetes levando a sua excreção pela urina, fortalece a hipótese de que participaria da doença; quando expresso por plaquetas e seus precursores estimula a proliferação eritróide e agregação plaquetária; e em modelos de injúria isquêmica cerebral em que é expresso por neurônios e astrócitos induz aumento autócrino na expressão de VEGF, prostaglandina E (PGE2) e do receptor de PGE2 (Gilissen et al., 2016).

Rubic-Schneider et al. (2008) demonstraram que células dendríticas derivadas de monócitos (MoDCs) de humanos e de camundongos expressam SUCNR1 e que a sinalização do receptor induz a migração e ativação das MoDCs. Anos mais tarde Kim et al. (2014) demonstraram que o succinato é o metabólito mais acumulado em líquido sinovial de pacientes com artrite reumatoide. Tais estudos embasaram o trabalho de Saraiva et al. (2018), no qual 
demonstrou-se que no modelo experimental de artrite reumatoide as células dendríticas imaturas expressam SUCNR1 e que essa expressão é responsável pela migração das DCs para os linfonodos drenantes onde induzem expansão de células T CD4+ produtoras de IL-17 e contribuem para patologia observada no modelo. Considerando que as células dendríticas desempenham papel central no desenvolvimento da psoríase e do seu modelo experimental, que assim como a artrite reumatoide apresentam elevada produção de IL-17, questionamos se o succinato e seu receptor SUCNR1 possuem algum papel na imunopatologia da psoríase. 


\section{HIPÓTESE}

O SUCNR1 expresso por dDCs contribui para ativação e migração destas células para os linfonodos drenantes onde induzem a ativação e diferenciação de células $\mathrm{T}$ auxiliares produtoras de IL-17, as quais migram para pele onde atuam na manutenção do processo inflamatório e formação das lesões observadas na psoríase. 


\section{OBJETIVOS}

\subsection{Geral}

Investigar o papel do succinato e seu receptor na psoríase experimental.

\subsection{Específicos}

- Avaliar a expressão do SUCNR1 no modelo experimental de psoríase induzido por imiquimode;

- Avaliar a relevância do SUCNR1 para o desenvolvimento do modelo experimental de psoríase;

- Investigar a origem da(as) célula(as) que expressa(am) SUCNR1 bem como a importância biológica da expressão de SUCNR1 por células hematopoiéticas e não hematopoiéticas no modelo experimental de psoríase;

- Avaliar a relevância do succinato no modelo experimental de psoríase. 


\section{MATERIAIS E MÉTODOS}

\subsection{Animais}

Camundongos das linhagens C57BL/6 e GPR91 KO com idades entre 8-12 semanas provenientes do Biotério Central da Universidade de São Paulo campus Ribeirão Preto (USPRP) e B6.FVB-1700016L21RikTg (Itgax-DTR/EGFP) 57Lan/J (CD11c-DTR/GFP) provenientes do The Jackson Laboratory, foram mantidos nos Biotérios dos Departamentos de Farmacologia e de Bioquímica da Faculdade de Medicina de Ribeirão Preto da Universidade de São Paulo (FMRP-USP). Os animais foram aleatoriamente distribuídos entre seus grupos em gaiolas $(30 \times 20 \times 13 \mathrm{~cm})$ em estante ventilada com água e dieta ad libitum. O projeto intitulado "Papel do Receptor de Succinato 1 (SUCNR1/GPR91) na Imunopatologia da Psoríase" sob o protocolo $\mathbf{n}^{\mathbf{0}}$ 111/2019 está de acordância com os princípios éticos em pesquisa animal adotados pelo Conselho Nacional de Controle de Experimentação Animal (CONCEA) e foi aprovado pela Comissão de Ética no Uso de Animais (CEUA) local da FMRP-USP.

\subsection{Modelo de Inflamação da Pele Induzida por Imiquimode}

No modelo de inflamação induzida por imiquimode na pele do dorso dos animais os pelos foram removidos dois dias antes do início da indução com depilador elétrico e no dia anterior com creme depilatório. A indução do modelo consistiu em aplicação de 1,5 mg de imiquimode (IMQ) à 5\% por orelha e/ou $3 \mathrm{mg}$ de IMQ à $5 \%$ no dorso de cada animal diariamente durante o período de sete dias. A espessura da orelha/dorso foi aferida diariamente com paquímetro previamente à aplicação de IMQ. Para realização dos procedimentos descritos os animais foram anestesiados com isoflurano à $2 \%$ em capela de fluxo laminar. No quarto e/ou sétimo dia do tratamento, referentes aos dias três e seis da timeline, foi realizada a eutanásia dos animais com overdose de xilazina (20 mg/kg) e cetamina (20 mg/kg), com inoculação de $100 \mu \mathrm{l}$ via plexo retro-orbital.

\subsection{Tratamento com Succinato}

Camundongos C57BL/6 foram tratados com IMQ, succinato na dose de 1,8 mg/animal, via tópica, no dorso dos camundongos, durante sete dias. Esta concentração foi utilizada para que o creme de succinato apresente uma molaridade próxima ao creme de imiquimode.

\subsection{Modelo de Construção de Camundongos Quimera}

Animais doadores C57BL/6 e SUCNR1 $1^{-/}$entre seis e sete semanas foram eutanasiados, seus fêmures e tíbias foram dissecados e coletados em placa Petri contendo meio RPMI completo. Dentro do fluxo laminar as epífises foram seccionadas e foi injetado meio RPMI completo com uma seringa de $10 \mathrm{~mL}$ e uma agulha $(25 \mathrm{x} 0,7 \mathrm{~cm})$ na cavidade medular liberando a medula óssea (MO) pela região seccionada (flush de MO) em tubo Falcon 50 mL. Após o 
flush o conteúdo foi homogeneizado com pipeta Pasteur estéril, os tubos Falcon foram centrifugados $\left(6 \mathrm{~min}, 4^{\circ} \mathrm{C}, 500 \mathrm{G}\right)$ e o sobrenadante descartado. O pellet foi ressuspendido em $2 \mathrm{~mL}$, foi realizado a contagem celular e diluição da suspensão para obtenção de $5 \times 10^{6}$ células de $\mathrm{MO} / 50 \mu \mathrm{L}$. Animais receptores C57BL/6 e SUCNR1 ${ }^{-/-}$entre 10 e 12 semanas foram irradiados com 7 Gy e após 24 horas transplantados com $5 \times 10^{6}$ células de MO via intravenosa, pela veia peniana. Durante duas semanas os receptores foram tratados com antibiótico na concentração de $1 \mathrm{mg} / \mathrm{mL}$ diluídos na água. Após dois meses da reconstituição foi iniciado o protocolo de indução de psoríase com IMQ durante sete dias. Durante todo o período de manutenção destes animais no biotério, as caixas, ração e água eram autoclavadas.

4.5. Cultura de Queratinócitos Humanos Imortalizados (HaCaT): a linhagem de queratinócitos humanos imortalizados (HaCat), foi gentilmente cedida pela Profa. Dra. Katiuchia Uzzun Sales (Departamento de Biologia Celular e Molecular FMRP/USP). Após o descongelamento as células foram expandidas e mantidas em meio de cultura DMEM (Dulbecco's Modified Eagle's, Thermo Fisher Scientific - Waltham, MA, EUA) contendo glicose $(4,5 \mathrm{~g} / \mathrm{L})$ e suplementado com soro bovino fetal $10 \%$, penicilina $(100 \mathrm{U} / \mathrm{mL})$, Lglutamina $(2 \mathrm{mM})$ e gentamicina $(0,2 \mathrm{mg} / \mathrm{mL})$, em estufa de $\mathrm{CO}_{2} 5 \%$, a $37^{\circ} \mathrm{C}$. Realizou-se até o máximo de 10 passagens. As células foram estimuladas com IL-17 recombinante humana à 100 ng/mL durante seis, 12 ou 24 horas.

\subsection{Processamento de Linfonodos Drenantes}

Após a eutanásia dos animais, os linfonodos cervicais (drenantes da orelha) e/ou os linfonodos axilares, braquiais e inguinais (drenantes do dorso), dLNs, foram dissecados e coletados para cell strainer de $70 \mu \mathrm{m}$ em placa de cultura de seis poços contendo meio RPMI, macerados com o embolo de seringa de $3 \mathrm{~mL}$ e a suspensão celular obtida foi transferida para tubo Falcon de $15 \mathrm{~mL}$ através de cell strainer $40 \mu \mathrm{m}$. Os tubos foram centrifugados ( $5 \mathrm{~min}$, $4^{\circ} \mathrm{C}, 450 \mathrm{G}$ ), o sobrenadante descartado e o pellet ressuspendido em $2 \mathrm{~mL}$ de meio RPMI completo (RPMI contendo $10 \%$ de SBF, $100 \mathrm{U} / \mathrm{mL}$ de penicilina, $0,125 \mu \mathrm{L} / \mathrm{mL}$ de fungizona e $2 \mathrm{mM}$ de glutamina). Em seguida, foi realizada contagem das células da suspensão.

\subsection{Processamento da Pele}

Após a eutanásia, a orelha e/ou pele do dorso do animal foi coletada por secção e foi injetado com seringa de $1 \mathrm{~mL}$ e agulha $(13 \times 0,45 \mathrm{~cm}), 500 \mu \mathrm{L}$ de solução de digestão (HBSS contendo 10\% de SBF, $10 \mathrm{mM}$ de HEPES, $5 \mathrm{mM}$ de EDTA, $200 \mu \mathrm{g} / \mathrm{mL}$ de DNAse e $1 \mathrm{mg} / \mathrm{mL}$ de Colagenase) na camada epidérmica da orelha ou na derme da pele do dorso. A pele contendo solução de digestão foi colocada em tubo Eppendorf $2 \mathrm{~mL}$ ao qual foi acrescentado $500 \mu \mathrm{L}$ de solução de digestão. A pele foi picotada e o Eppendorf foi colocado no gelo até o fim do preparo 
de todas as amostras. Após o preparo das amostras, os tubos Eppendorf foram incubados em banho seco à $37^{\circ} \mathrm{C}$ com agitação de 900 rpm durante 30 min. Após incubação, o conteúdo do e

Eppendorf foi coletado e transferido para tubo Falcon contendo $10 \mathrm{~mL}$ de meio HBSS completo (HBSS contendo 10\% de SBF, $10 \mathrm{mM}$ de HEPES, $5 \mathrm{mM}$ de EDTA) gelado, centrifugado $\left(5 \mathrm{~min}, 4^{\circ} \mathrm{C}, 450 \mathrm{G}\right)$ e o sobrenadante descartado. $\mathrm{O}$ pellet foi ressuspendido em 2 $\mathrm{mL}$ de meio RMPI completo e as amostras foram transferidas para placa de seis poços nas quais foram maceradas em cell strainer de $70 \mu \mathrm{m}$ com o embolo de seringa de $3 \mathrm{~mL}$. Com uma pipeta Pasteur a suspensão celular obtida foi transferida para tubo Falcon de $15 \mathrm{~mL}$ através de cell strainer de $40 \mu \mathrm{m}$. A suspensão celular foi centrifugada $\left(5 \mathrm{~min}, 4^{\circ} \mathrm{C}, 450 \mathrm{G}\right)$ e o sobrenadante descartado. O pellet foi ressuspendido em $1 \mathrm{~mL}$ de meio RMPI completo e foi realizado contagem celular.

\subsection{Citometria de Fluxo}

Células processadas dos dLNs e/ou da pele foram plaqueadas em placa de citometria de 96 poços à 2 milhões de células por poço. Para a realização de marcação intracelular de citocinas a placa foi centrifugada $\left(5 \mathrm{~min}, 4^{\circ} \mathrm{C}, 450 \mathrm{G}\right)$ e os pellets ressuspendidos em $100 \mu \mathrm{l} /$ poço de solução de estímulo (meio RPMI completo contendo $50 \mathrm{ng} / \mathrm{ml}$ de PMA, $500 \mathrm{ng} / \mathrm{ml}$ de ionomicina e $1,5 \mu \mathrm{l} / \mathrm{ml}$ de Golgi Stop). A placa foi incubada em estufa de $\mathrm{CO}_{2}$ à $37^{\circ} \mathrm{C}$ durante quatro horas. Após o estímulo a placa foi centrifugada $\left(5 \mathrm{~min}, 4^{\circ} \mathrm{C}, 450 \mathrm{G}\right)$, os sobrenadantes descartados e os pellets ressuspendidos em $50 \mu 1$ poço de solução das marcações extracelulares (PBS contendo 10\% de SBF, probe de viabilidade 1:3 mil, demais anticorpos 1:200). A placa foi incubada por $15 \mathrm{~min}$, centrifugada $\left(5 \mathrm{~min}, 4^{\circ} \mathrm{C}, 450 \mathrm{G}\right)$, os sobrenadantes descartados e os pellets ressuspendidos em $50 \mu \mathrm{l} /$ poço de fixador (fixation/permeabilization concentrated 40x diluído para 1x em solução fixation do kit). A placa foi incubada por $15 \mathrm{~min}$, centrifugada (5 $\left.\min , 4^{\circ} \mathrm{C}, 450 \mathrm{G}\right)$, os sobrenadantes descartados e os pellets ressuspendidos em $50 \mu \mathrm{l} /$ poço de permeabilizante (permwash 10x diluído para 1x em PBS 1x). A placa foi encubada por 15 min, centrifugada $\left(5 \mathrm{~min}, 4^{\circ} \mathrm{C}, 450 \mathrm{G}\right)$, os sobrenadantes descartados e os pellets ressuspendidos em $50 \mu 1 /$ poço de solução das marcações intracelulares (permwash 1x contendo anticorpos na concentração de 1:200). A placa foi incubada por $15 \mathrm{~min}$, centrifugada $\left(5 \mathrm{~min}, 4^{\circ} \mathrm{C}, 450 \mathrm{G}\right)$, os sobrenadantes descartados e os pellets ressuspendidos em $100 \mu 1$ poço de PSB 1x.

Para detecção de linfócitos na pele foram utilizados probe de viabilidade e anticorpos anti-CD45, anti- $\alpha \beta$, anti- $\gamma \delta$ e anti-IL17. Para detecção de células dendríticas, foram utilizados anticorpos anti-CD45 e anti-CD11c. Para detecção de células dendríticas provenientes de camundongos CD11c-DTR/GFP não foi utilizado anti-CD11c pois nesta linhagem a região promotora do gene CD11c é flanqueada ao gene da proteína verde fluorescente (GFP), portanto 
todas as células anti-CD11c+ emitem fluorescência no canal FITC.. As células foram adquiridas em aparelhos FACS Verse e Canto II (BD Bioscience).

\subsection{Sorting de Células da Pele}

Após a contagem das células os tubos Falcon foram centrifugados $\left(5 \mathrm{~min}, 4^{\circ} \mathrm{C}, 450 \mathrm{G}\right)$, o sobrenadante descartado e o pellet ressuspendido em $2 \mathrm{~mL}$ de solução da marcação (PBS contendo 10\% de SBF, probe de viabilidade 1:3 mil, demais anticorpos 1:200). Os tubos foram incubados por $15 \mathrm{~min}$, após centrifugados $\left(5 \mathrm{~min}, 4^{\circ} \mathrm{C}, 450 \mathrm{G}\right)$, o sobrenadante descartado e os pellets ressuspendidos em $1 \mathrm{~mL}$ de meio RMPI completo. O sorting de células CD45-, CD45+, CD45-CD11c-, CD45-CD11c+, CD45+CD11c- e CD45+CD11c+ foi realizado em aparelho Canto II (BD Bioscience). As células sorteadas foram ressuspendidas em tubos Falcon contendo 1,5 mL de meio RPMI completo e 1,5 mL de SBF.

\subsection{Reação em Cadeia da Polimerase}

4.10.1. Extração de RNA: Coletou-se entre 30 e $60 \mathrm{mg}$ de pele e linfonodo por animal e colocados em $300 \mu \mathrm{L}$ de RNAlater (Qiagen ${ }^{\circledR}$ ) o quais foram armazenados por até 48 horas em $4^{\circ} \mathrm{C}$. Posteriormente adicionou-se $500 \mu \mathrm{L}$ de Trizol e homogeneizou-se as amostras, foi realizado a centrifugação destas $\left(12\right.$ mil G por três minutos, a $\left.25^{\circ} \mathrm{C}\right)$, o sobrenadante foi coletado para outro eppendorf e foram adicionados $100 \mu \mathrm{L}$ de clorofórmio em cada, os Eppendorfs foram vortexados por 15 segundos e centrifugados $\left(12\right.$ mil G por três minutos, a $\left.25^{\circ} \mathrm{C}\right)$, o sobrenadante transparente (aproximadamente $300 \mu \mathrm{L}$ ) foi coletado para outro Eppendorf. Foram adicionados $300 \mu \mathrm{L}$ de álcool $70 \%$ e homogeneizados, o volume de $600 \mu \mathrm{L}$ foi coletado e pipetado na coluna do kit RNAsey Mini Kit 250 (Qiagen) seguindo as instruções do fabricante.

As amostras foram centrifugadas ( 8 mil $\mathrm{G}$ por 30 segundos, a $20^{\circ} \mathrm{C}$ ), o líquido que desceu para o tubo foi descartado e o tubo reutilizado na sua respectiva coluna, $700 \mu \mathrm{L}$ de Buffer $R W 1$ foi adicionado em cada coluna, as amostras foram centrifugadas ( 8 mil G por 30 segundos, a $20^{\circ} \mathrm{C}$ ), o líquido que desceu para o tubo foi descartado e o tubo reutilizado na sua respectiva coluna, $700 \mu \mathrm{L}$ de Buffer RPE foi adicionado em cada coluna, as amostras foram centrifugadas ( 8 mil $\mathrm{G}$ por 2 minutos, a $20^{\circ} \mathrm{C}$ ), as colunas foram colocadas em tubos novos, as amostras centrifugadas $\left(13,5\right.$ mil $\mathrm{G}$ por 1 minuto, a $\left.20^{\circ} \mathrm{C}\right)$, as colunas foram colocadas em tubos Eppendorf 1,5 mL e foram adicionados $20 \mu \mathrm{L}$ de água Sigma nas colunas, as amostras foram centrifugadas $\left(10\right.$ mil G por 1 minuto, a $\left.20^{\circ} \mathrm{C}\right)$, as colunas foram desprezadas e os tubos Eppendorf contendo RNA armazenados em freezer $-70^{\circ} \mathrm{C}$ até o momento de quantificação e conversão em cDNA.

4.10.2. Conversão em cDNA: para conversão em cDNA utilizou-se o kit High Capacity (Life Technologies). o RNA extraído foi quantificado por leitura em NanoDrop, $1 \mu \mathrm{L}$ de cada 
amostra foi pipetado no aparelho e a concentração anotada. Foi realizado cálculo para que se obtivesse $500 \mathrm{ng}$ de RNA de cada amostra. As amostras foram diluídas em água Sigma para um volume final de 14,2 $\mu \mathrm{L}$. Utilizou-se $1 \mu \mathrm{L}$ /amostra de transcriptase reversa, $2 \mu \mathrm{L} /$ amostra de RT Buffer, $2 \mu \mathrm{L} / \mathrm{amostra}$ de random prime e $0,8 \mu \mathrm{L} / \mathrm{amostra}$ de dNTP MIX. Foi realizado PCR convencional em aparelho Termociclador da Thermofisher, com configurações do ciclo conforme indicado pelo kit. As amostras foram armazenadas em freezer $-20^{\circ} \mathrm{C}$ até o momento do qRT-PCR.

4.10.3. PCR em tempo real: coletou-se $1 \mu \mathrm{L}$ de cada amostra, $5 \mu \mathrm{L}$ de Sybr ${ }^{\circledR}$ Green Master Mix (Thermo Fisher Scientific), 0,25/ $\mu \mathrm{L}$ de primers forward e reverse e 3,5 $\mu \mathrm{L}$ de água sigma para cada amostra. A expressão dos genes de interesse: $1117 a$ (Foward: GCTCCAGAAGGCCCTCAG, Reverse: CTTTCCCTCCGCATTGACA), Illb (Foward: TGACAGTGATGAGAATGACCTGTTC, Reverse: TTGGAAGCAGCCCTTCATCT), Il23 (Foward: CACCTCCCTACTAGGACTCAGC; Reverse: CTGCCACTGCTGACTAGAAC), K14 (Forward: GGCCTGCTGAGATCAAAGACTAC; Reverse:

CACTGTGGCTGTGAGAATCTTGTT), Lcn2 (Forward: CCCCATCTCTGCTCACTGTC; Reverse: TTTTTCTGGACCGCATTG) e Sucnrl (Foward: GACAGCAGAATGGCACAG; Reverse: CATTCCCAAGCAGTCCAAA) foi quantificada no aparelho StepOne Real-Time PCR System (Applied Biosystems). Os resultados foram analisados através do método de 2$\Delta \Delta \mathrm{ct}$ em comparação a expressão do endógeno Gapdh (Forward: CATCTTCTTGTGCAGTGCCA; Reverse: CGGCCAAATCCGTTCAC), avaliando-se assim a expressão relativa.

\subsection{Ensaio Imunoenzimático}

Pele do dorso e o soro proveniente do PBMC de animais e sobrenadante das culturas celulares foram coletados para realização de ELISA de citocinas e armazenados em freezer $20^{\circ} \mathrm{C}$. As amostras de tecido foram ressuspendidas em $450 \mu \mathrm{L}$ de PBS contendo inibidores de protease $(1: 25)$ e fosfatase $(1: 100)$ e EDTA $(1 \mathrm{mM})$. As amostras foram processadas em Politron, centrifugadas ( $10 \mathrm{mil} \mathrm{G}$ por $10 \mathrm{~min}, 4^{\circ} \mathrm{C}$ ), o sobrenadante foi coletado e armazenado em freezer $20^{\circ} \mathrm{C}$. As amostras foram quantificadas a partir de BCA, para tanto uma alíquota de cada foi diluída dez vezes em água RNAse free da Sigma, a solução A (BCA Sigma) foi diluída em reagente B (sulfato de cobre) na concentração de 50:1, $200 \mu \mathrm{L} /$ poço. Foi pipetado BSA para curva com alcance de $1000 \mathrm{mg} / \mathrm{mL}$ até $7,81 \mathrm{mg} / \mathrm{mL}$. A leitura foi realizada em aparelho SpectraMAX 190.

Para ensaio de ELISA foi realizado coating overnight da placa com anticorpos de captura para proteína de interesse: IL-17, IL-23 e IL-1 $\beta$, em temperatura ambiente. No dia 
seguinte a placa foi lavada duas vezes com PBS 1x Tween 0,1\% e uma terceira vez com PBS 1x. Foi realizado o bloqueio para ligações inespecíficas com PBS 1x BSA 2\% e em seguida lavagem, então pipetou-se a curva, as amostras foram pipetadas diluídas 4 vezes e a placa foi e incubada overnight em temperatura ambiente. No dia seguinte, a placa foi lavada, pipetou-se anticorpos de detecção para proteína de interesse e a placa incubada em estufa de $\mathrm{CO}_{2}$, a $37^{\circ} \mathrm{C}$ por uma hora. Em seguida a placa foi lavada e foi pipetado streptoavidina diluída em BSA $1 \%$ na concentração de 1:40, encubou-se a placa por 40 minutos protegida da luz em temperatura ambiente, após realizou-se a lavagem e por fim pipetou-se $100 \mu \mathrm{L}$ /poço de substrato TMB puro. A leitura foi realizada em aparelho SpectraMAX 190 no comprimento de onda de $630 \mathrm{~nm}$.

\subsection{Hematoxilina Eosina}

Parte da orelha dos animais foi coletada e mantida em PFA 4\% por até uma hora, as amostras foram desidratadas em sacarose $30 \%$ por 24 horas e armazenadas em álcool $70 \%$. Após essa etapa, fragmentos de tecidos foram emblocados em parafina, cortados e aderidos à lâminas, as quais foram desparafinizadas, hidratadas, lavadas, coradas com hematoxilina, eosina, desidratadas e então fixadas. Foram avaliadas características microscópicas da pele, como infiltrado inflamatório, acantose, paraqueratose, hiperqueratose, dentre outros.

\subsection{Imunofluorêscencia}

Parte da orelha dos animais, células das culturas primárias e biópsia da pele de humanos foi coletada e mantida em PFA 4\% por até 1 horas, ressecado com sacarose a 30\% por 24 horas e então emblocado com Tissue-tek, cortado e aderido à lâminas gelatinizadas em aparelho na espessura de $20 \mathrm{~mm}$ por corte, as lâminas foram lavadas três vezes, duas com TBS e uma com água miliQ, tratadas com glicina $(0,1 \mathrm{M})$ por 20 minutos, lavadas, permeabilizadas com Triton x100 a 0,2\% diluído em PBS 1x BSA 1\% por 30 minutos e lavadas. Os anticorpos primários foram diluídos em PBS 1x BSA 1\% nas concentrações de 1:400, 1:200 ou 1:50 e as lâminas incubadas overnight em câmara úmida a $4^{\circ} \mathrm{C}$. No dia seguinte as lâminas foram lavadas, e os anticorpos secundários diluídos em PBS 1x BSA 1\% na concentração de 1:400 foram adicionados e incubados por uma hora, as lâminas foram então lavadas, secas, o DAPI foi adicionado e as lamínulas postas sobre as lâminas. Foram utilizados anticorpos para avaliação de ativação de queratinócitos como K17, K14, LCN2 e S100A9, e para o receber estudado SUCNR1. As imagens foram obtidas por microscopia de fluorescência em equipamento Leica CTR H5 e por microscopia confocal em equipamento Nikon ECLIPSE Ti2.

\subsection{Hibridização in situ}

Após o terceiro dia do protocolo de indução com IMQ, os animais foram eutanasiados e perfundidos com PFA 4\%, após isso as amostras de pele coletadas foram incubadas em PFA 
$4 \%$ entre $4^{\circ} \mathrm{C}$ e $8^{\circ} \mathrm{C}$ por até duas horas. Após este período foram lavadas e ressecadas com sacarose à $10 \%$ por 24 horas, sacarose à $20 \%$ por 48 horas e sacarose à $30 \%$ por 48 horas. Os tecidos foram cortados, tratados com peróxido de hidrogênio do kit de RNAscope ${ }^{\circledR}$ Multiplex FL por 10 minutos em temperatura ambiente, as laminas foram lavadas, incubadas com protease do kit por 30 minutos em $40^{\circ} \mathrm{C}$, lavadas e incubadas com a probe para o mRNA do SUCNR1 durante duas horas em temperatura ambiente, lavadas e o protocolo de imunofluorescência para K17 foi realizado.

\subsection{Análise Estatística}

A análise estatística foi realizada por ANOVA, através do Teste de Comparação Múltipla de Bonferroni e Teste t não paramétrico com nível de significância estabelecido em $5 \%$ (p-value $<0,05$ ). A análise estatística e os gráficos foram construídos utilizando o programa computacional GraphPad Prism (GraphPad Software, San Diego, CA, EUA). Os gráficos de dotplot de citometria foram construídos utilizando-se o FlowJo VX. 


\section{RESULTADOS}

\subsection{A expressão de Sucnr1 na pele está aumentada no modelo experimental de psoríase}

Saraiva et al. (2018) observaram aumento na expressão do Sucnr1 nos dLNs da articulação patelofemoral, assim, iniciamos este trabalho investigando se a expressão de Sucnr1 é modulada nos dLNs da pele e/ou na pele de camundongos na psoríase experimental. Para tanto, os animais foram tratados com IMQ durante quatro dias, iniciando o tratamento no dia zero e realizando a eutanásia no dia três para coleta dos dLNs e da pele para realização de qRTPCR (Figura 1A). O dia três foi escolhido por se tratar do início do processo inflamatório e das alterações patológicas induzidas pelo IMQ, sendo também o melhor dia observado pelo nosso grupo para detecção de modulação de mRNA pelo fármaco.

Observamos aumento significativo na expressão de Sucnrl na pele dos animais induzidos com IMQ em relação aos animais controles (naive), que não receberam indução (Figura 1C). No entanto, verificamos que o receptor não é expresso nos linfonodos drenantes no modelo experimental de psoríase (Figura 1B). Este resultado demonstra que o IMQ modula direta ou indiretamente a expressão do Sucnr1 na pele de camundongos, sugerindo que este pode exercer alguma função na fisiopatologia da psoríase experimental.

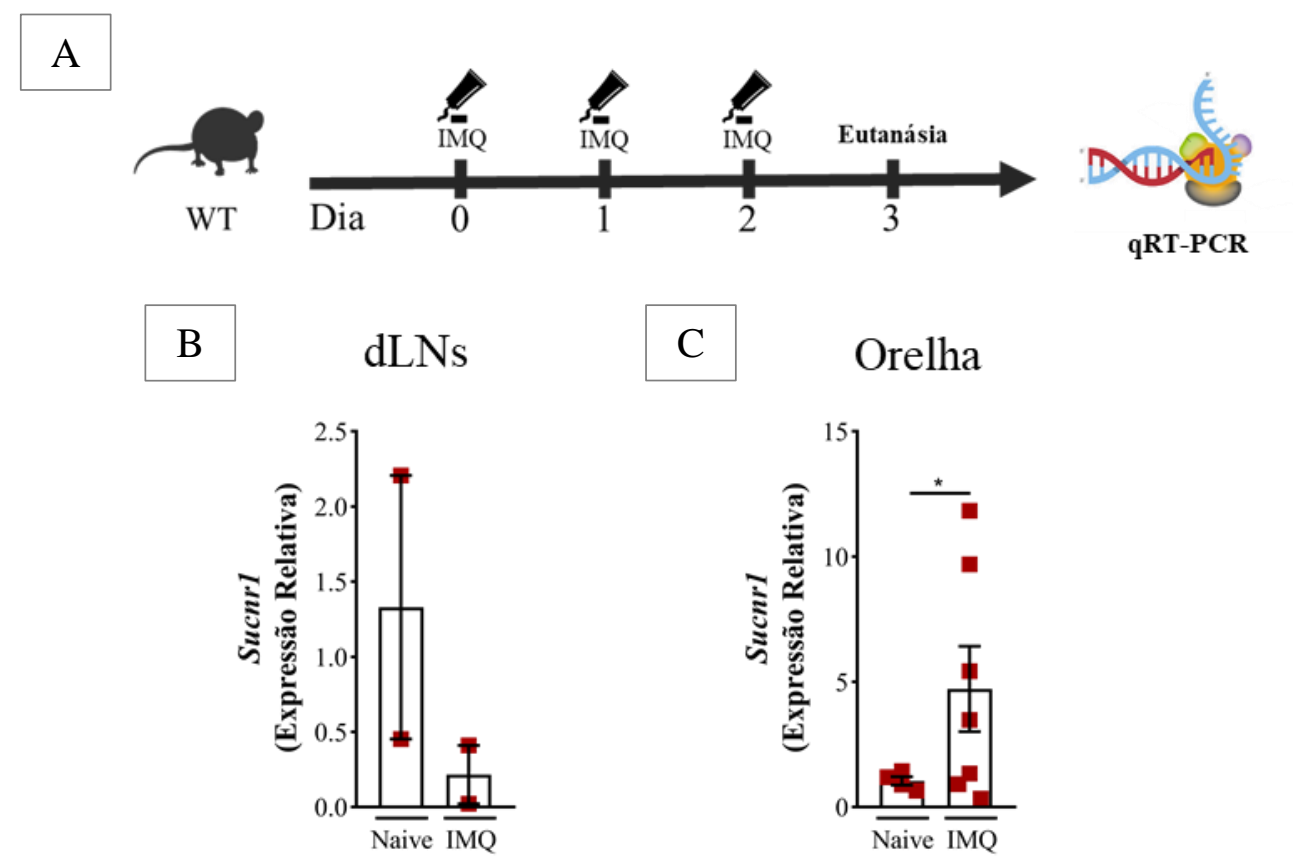

Figura 5. Expressão de SUCNR1 no modelo experimental de psoríase. Animais C57BL/6 (WT) foram tratados ou não com $3 \mathrm{mg}$ de IMQ a 5\% topicamente durante três dias (A). A pele dos animais foi coletada, o RNA extraído e convertido para realização de qRT-PCR para Gapdh e Sucnrl nos dLNs (B) e na orelha (C). A expressão é relativa ao Gapdh. O gráfico apresenta média \pm SEM. *P $<0,05$ foi considerado estatisticamente significante. 


\subsection{O Sucnr1 contribui para o aumento na espessura e no eritema da pele induzidos por} IMQ

O aumento na expressão do Sucnr1 pelo IMQ associado aos dados da literatura em que o receptor é descrito auxiliando o desenvolvimento de processos inflamatórios, sugerem que, na ausência do receptor a psoríase experimental poderia se manifestar de maneira atenuada. Desta forma, iniciamos o protocolo de indução de psoríase em animais selvagens (WT) e deficientes para o Sucnr1 (SUCNR $\left.1^{-/}\right)($Figura 6A) e realizamos a coleta de material biológico em dois tempos diferentes, considerando ensaios do grupo nos quais alterações clínicas e proteicas são mais claramente observadas no dia seis do protocolo, com o objetivo de investigar alterações clínicas, proteicas e em níveis de mRNA.

Os animais SUCNR1 ${ }^{-/}$apresentaram menor espessura na pele ao longo do tratamento com IMQ em comparação aos animais WT (Figura 6B) diante da mensuração diária da pele do dorso, sugerindo haver menos edema e menor espessura na epiderme. Observamos ainda menos eritema e menos descamação na pele dos animais SUCNR $1^{-/}$, e que esta redução se torna mais perceptível no último dia do tratamento (Figura 6C). Este conjunto de resultados sugere que o Sucnr1 participa na indução da psoríase experimental. Os animais foram ainda pesados diariamente durante o protocolo de tratamento com IMQ para verificarmos possíveis alterações fisiológicas nos SUCNR1 ${ }^{-/}$em relação aos WT, observamos padrões de perda e recuperação de peso semelhantes entre os grupos (Figura 7A) sugerindo não haver alterações fisiológicas entre os animais e o peso dos baços dos animais estava semelhante entre os grupos (Figura 7B). 

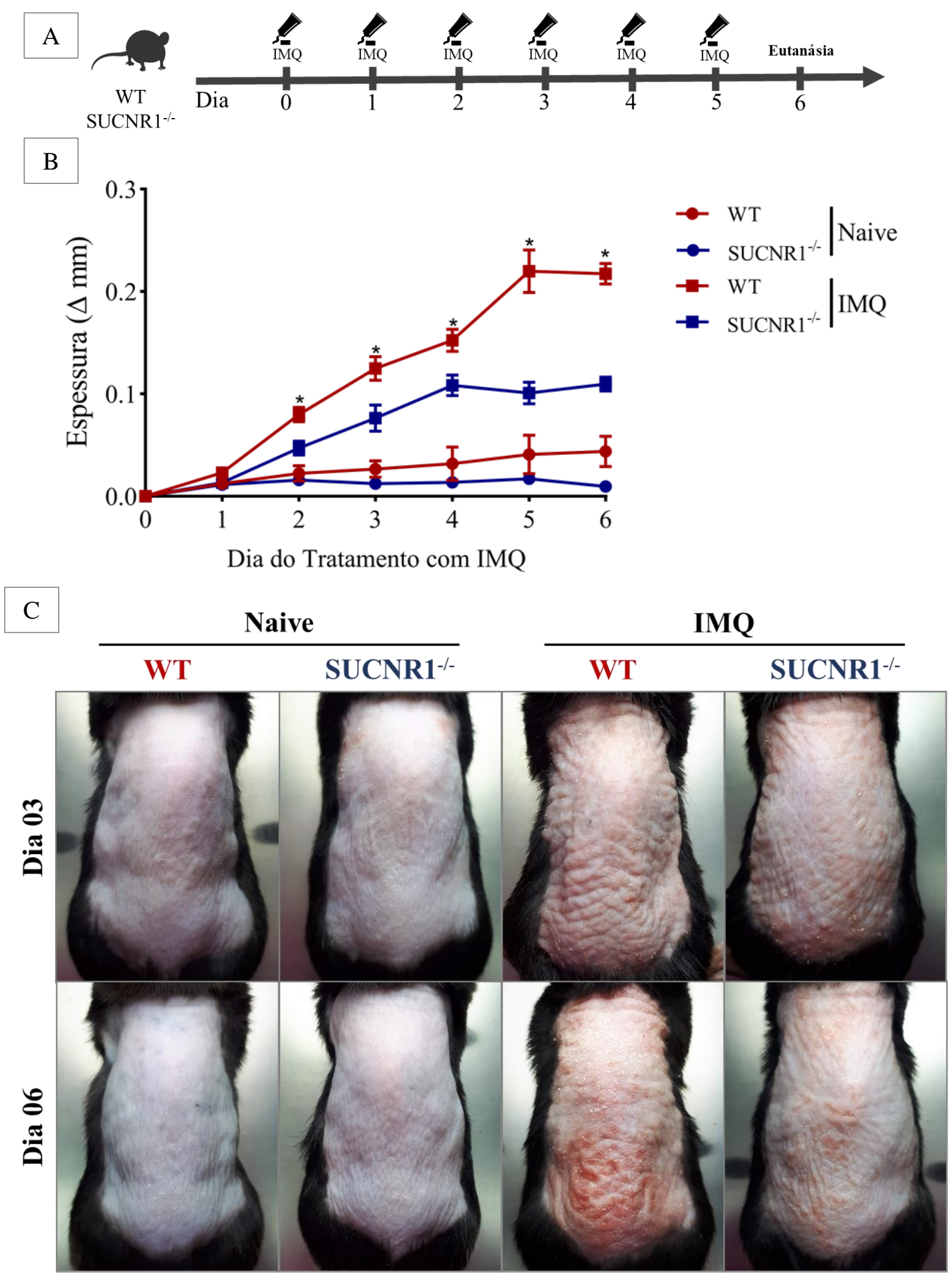

Figura 6. Participação do SUCNR1 na indução de edema, eritema e descamação da pele na psoríase experimental. Animais C57BL/6 (WT) e deficientes para Sucnr1 (SUCNR1 ${ }^{-/}$) foram tratados ou não com $3 \mathrm{mg}$ de IMQ a 5\% topicamente durante seis dias (A). A espessura da pele dos animais foi mensurada diariamente com paquímetro para obtenção do delta relativo ao primeiro dia, o dia $0(\mathbf{B})$. O dorso dos animais foi fotografado nos dias 3 e $6(\mathbf{C})$. O gráfico apresenta média \pm SEM. $* \mathrm{P}<0,05$ foi considerado estatisticamente significante. 

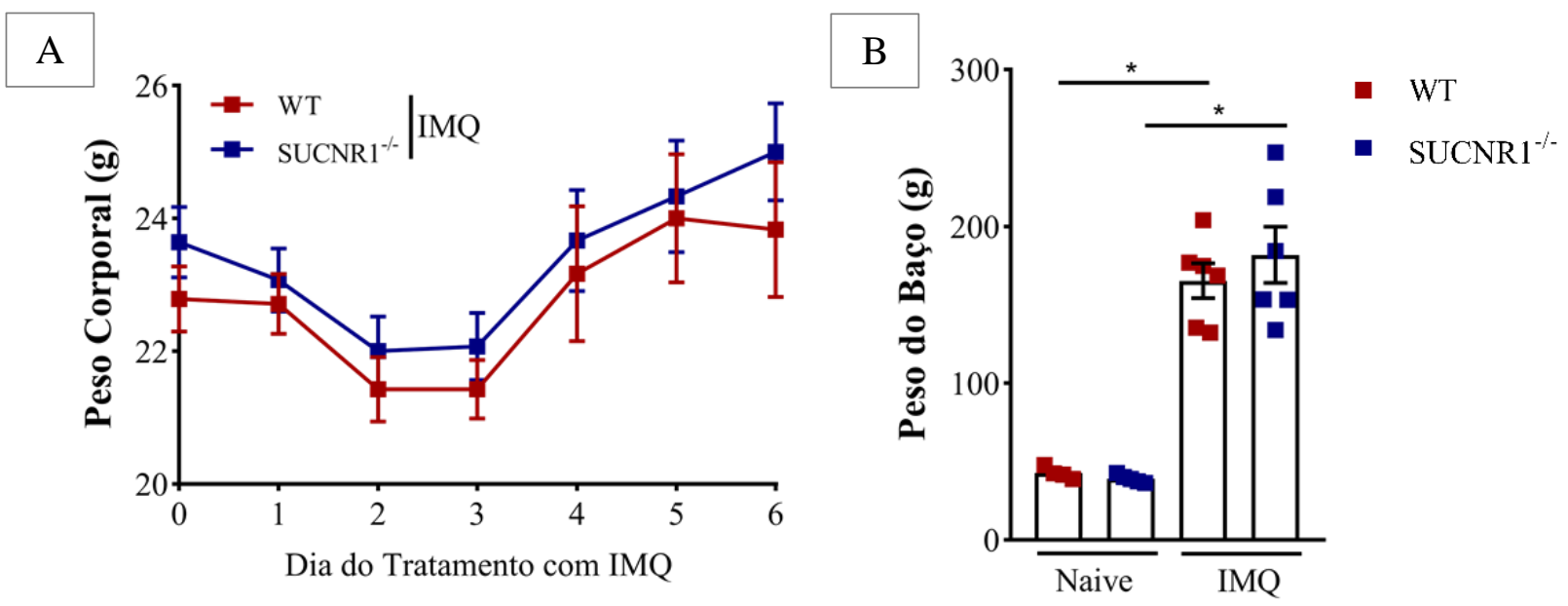

Figura 7. Peso corpóreo e do baço dos animais durante a indução de psoríase com IMQ. Animais C57BL/6 (WT) e deficientes para Sucnr1 $\left(\mathrm{SUCNR}^{-/-}\right.$) foram tratados ou não com 3 $\mathrm{mg}$ de IMQ a 5\% topicamente durante seis dias. Os animais foram pesados diariamente e os baços foram pesados no dia 6 referente a coleta. Os gráficos apresentam média \pm SEM. *P $<0,05$ foi considerado estatisticamente significante.

5.3. O Sucnr1 contribui para o aumento de edema, infiltrado inflamatório, acantose, hiperqueratose e paraqueratose no modelo experimental de psoríase

Os dados demonstrados na figura 6 sugerem que o Sucnr1 contribui para patologia induzida pelo IMQ e estaria envolvido no aumento da espessura da pele, que pode ocorrer devido à edema, aumento de líquido no espaço intersticial observado com maior espaçamento entre as fibras e células da derme; infiltrado inflamatório, acúmulo de células basofílicas na epiderme e/ou na derme; hiperqueratose, hiperproliferação de queratinócitos do estrato espinhoso; paraqueratose, presença de corneócitos nucleados; e/ou acantose, projeções papilares da epiderme para dentro da derme. Realizamos histologia da pele e coloração por hematoxilina e eosina (H\&E) nos dias três e seis (Figura 8), e constatamos mais acantose, hiperqueratose, paraqueratose, edema e infiltrado inflamatório na pele psoriática de animais WT em comparação aos animais SUCNR1 ${ }^{-/-}$, reforçando os achados da figura 6 de que o Sucnr1 contribui para disfunção na pele induzida pelo IMQ e sugere ainda que o Sucnr1 estaria envolvido no processo inflamatório induzido pelo IMQ. 


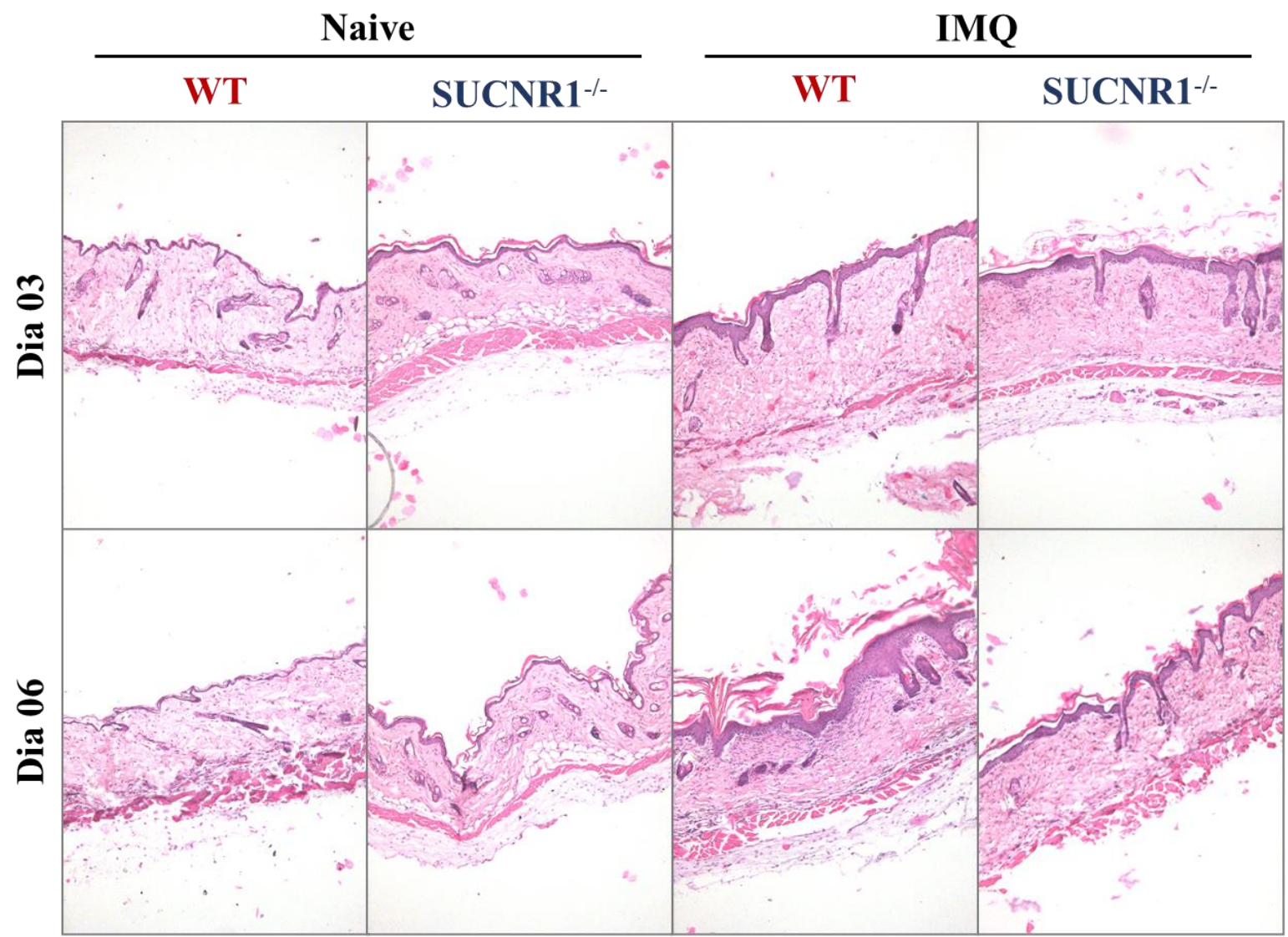

Figura 8. Histologia da pele psoriática. Animais C57BL/6 (WT) e deficientes para Sucnr1 $\left(\mathrm{SUCNR} 1^{-/}\right.$) foram tratados ou não com $3 \mathrm{mg}$ de imiquimode a $5 \%$ topicamente durante seis dias. A pele do dorso dos animais foi coletada nos dias 3 e 6 para cortes histológicos e coloração com H\&E. Objetiva de 10x.

\subsection{O Sucnr1 contribui para modulação de marcadores de ativação dos queratinócitos induzidos pelo IMQ}

Tanto a psoríase clínica quanto o seu modelo experimental são caracterizados pela disfunção de queratinócitos, os quais são centrais na doença, esta disfunção, por sua vez, é caracterizada pela intensa ativação e hiperproliferação dos queratinócitos (Albanesi et al., 2018; Moos et al., 2019). O IMQ é um fraco ativador de queratinócitos, desta forma, a IL-17A é a principal forma de ativação destes na psoríase e em seu modelo experimental (Moos et al., 2019). Quando ativados os queratinócitos entram em proliferação e expressam queratinas relacionadas a este estado, sendo a queratina 17 (K17) a de maior relevância e utilizada como biomarcador da pele psoriática (Leigh et al., 1995). Os queratinócitos ativados expressam ainda citocinas inflamatórias, dentre as quais a lipocalina, codificada pelo gene Lcn2 é também utilizada como biomarcador da doença (Mallbris et al., 2002). Portanto, neste passo realizamos coleta de pele no dia três para realização de qRT-PCR para avaliação da expressão de $K 17$ e de $L c n 2$ e no dia seis para realização de imunofluorescência para avaliação da expressão de K17. Observamos que na pele psoriática de animais SUCNR1 ${ }^{-/}$a expressão de K17, Lcn2 (Figura 
9A) e K17 (Figura 9B) está reduzida em comparação a pele psoriática de animais WT, sugerindo que o Sucnr1 contribui de alguma maneira para ativação de queratinócitos e que por isso a epiderme de animais $\mathrm{SUCNR}^{-/}$apresentaria menos hiperqueratose, acantose e paraqueratose.

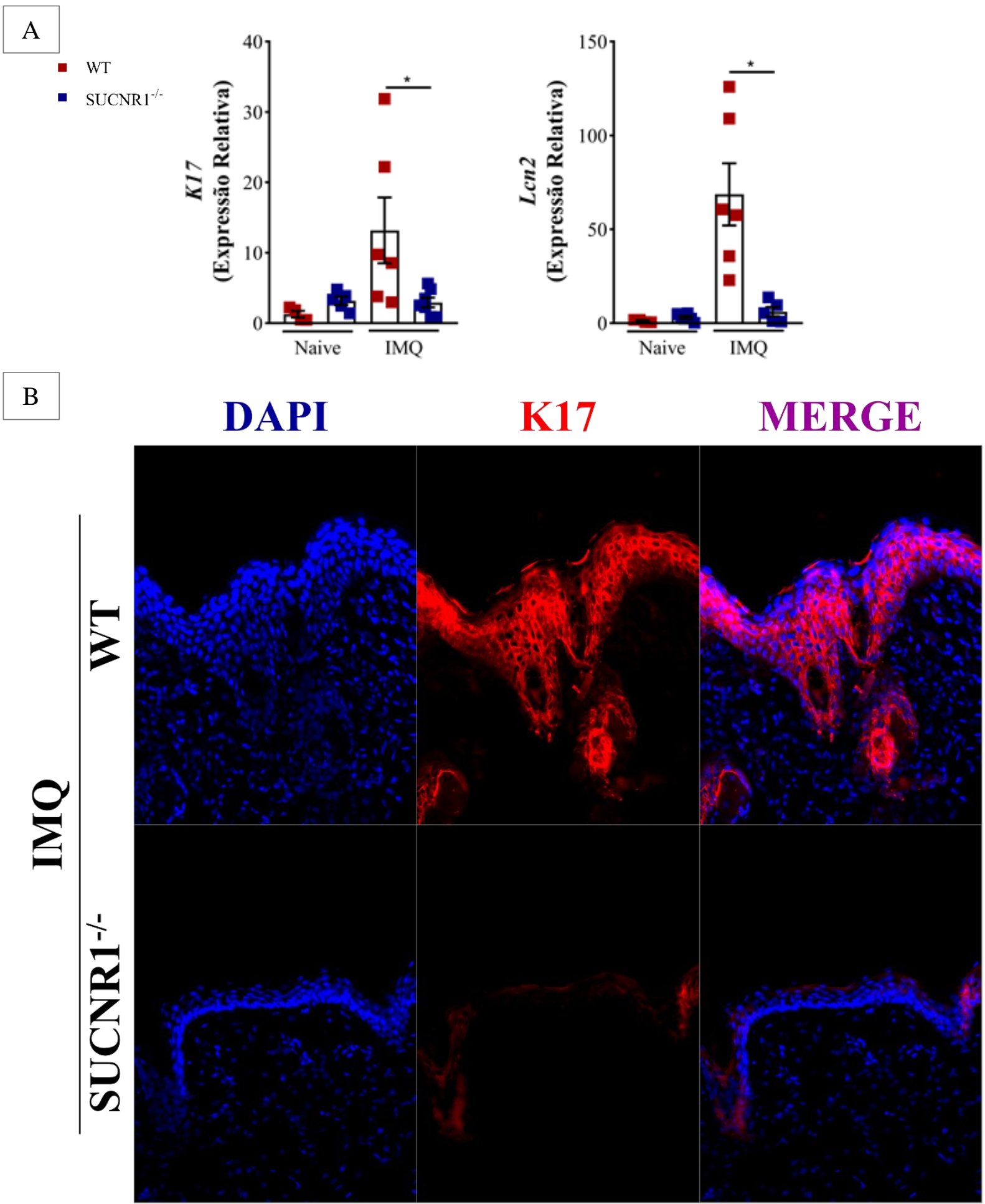

Figura 9. Marcadores de ativação de queratinócitos na psoríase experimental. Animais C57BL/6 (WT) e deficientes para Sucnr1 (SUCNR1 ${ }^{--}$) foram tratados ou não com $3 \mathrm{mg}$ de IMQ à $5 \%$ topicamente durante seis dias. No dia 3, parte da pele do dorso dos animais foi coletada, RNA extraído e convertido para realização de qRT-PCR para Gapdh, K17 e Lcn2 (A). A 
expressão é relativa ao Gapdh. Os gráficos apresentam média \pm SEM. $* \mathrm{P}<0,05$ foi considerado estatisticamente significante. Realizou-se imunofluorescência da pele do dorso para K17 (vermelho) e DAPI (azul) (B). Objetiva de 40x.

\subsection{O Sucnr1 contribui para expansão de células produtoras de IL-17 nos linfonodos na psoríase experimental}

Ao observamos que animais SUCNR $1^{-/-}$tratados com IMQ apresentam menor infiltrado inflamatório na pele, menos hiperqueratose, acantose, paraqueratose e menor expressão de marcadores de ativação de queratinócitos, questionamos se o Sucnr1 estaria favorecendo a diferenciação de células $\mathrm{T} \alpha \beta$ e $\gamma \delta$, as duas principais populações responsáveis pela produção de IL-17A na psoríase e em seu modelo experimental, que estão relacionadas à ativação de queratinócitos e por conseguinte à severidade da doença (Cai et al., 2011; Moos et al., 2019). Para tanto, avaliamos ambas as populações produtoras de IL-17 nos dLNs e verificamos que tanto as populações de células TCR $\beta+\mathrm{IL}-17+($ Figura 10 $)$ quanto de células $\gamma \delta+\mathrm{IL}-17+($ Figura 11) estão reduzidas nos animais SUCNR $1^{-1-}$.

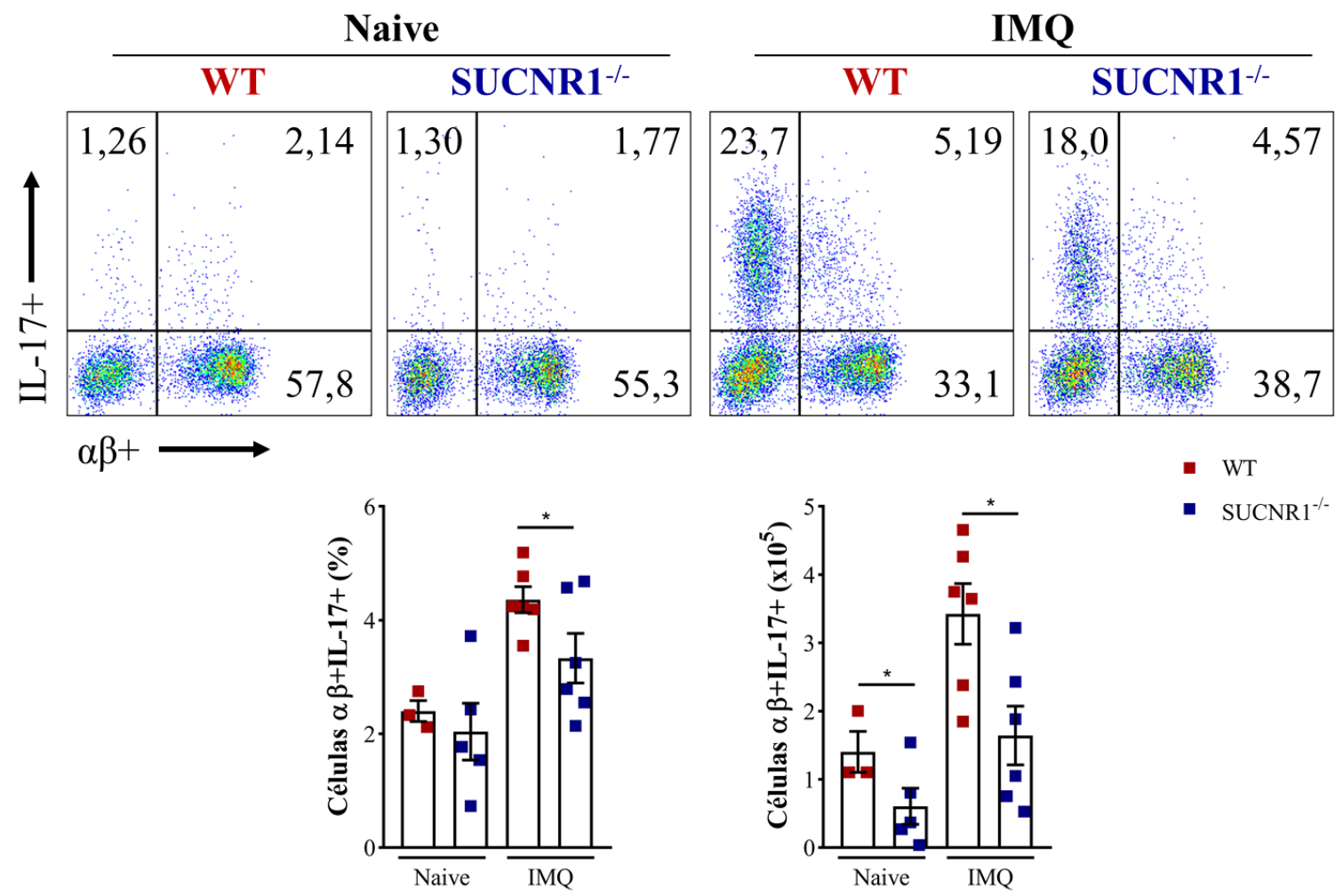

Figura 10. Células $T \alpha \beta$ produtoras de IL-17 na ausência do Sucnr1 em modelo experimental de psoríase. Animais C57BL/6 (WT) e deficientes para Sucnr1 (SUCNR1 ${ }^{-/}$) foram tratados ou não com $3 \mathrm{mg}$ de IMQ a $5 \%$ topicamente durante seis dias. A suspensão celular dos linfonodos drenantes do dorso (dLNs) foi obtida e marcadas com probe de viabilidade (viadye) (APC.Cy7). Os dotplots foram pre-gateados em SSC-A/H, SSC-A/FSC-A e viadye negativo. A população de células T $\alpha \beta$ produtoras de IL-17 marcadas com anti-TCR $\beta$ 
(APC) e e anti-IL-17 (PE). Os gráficos apresentam média \pm SEM. *p $<0,05$ foi considerado estatisticamente significante.

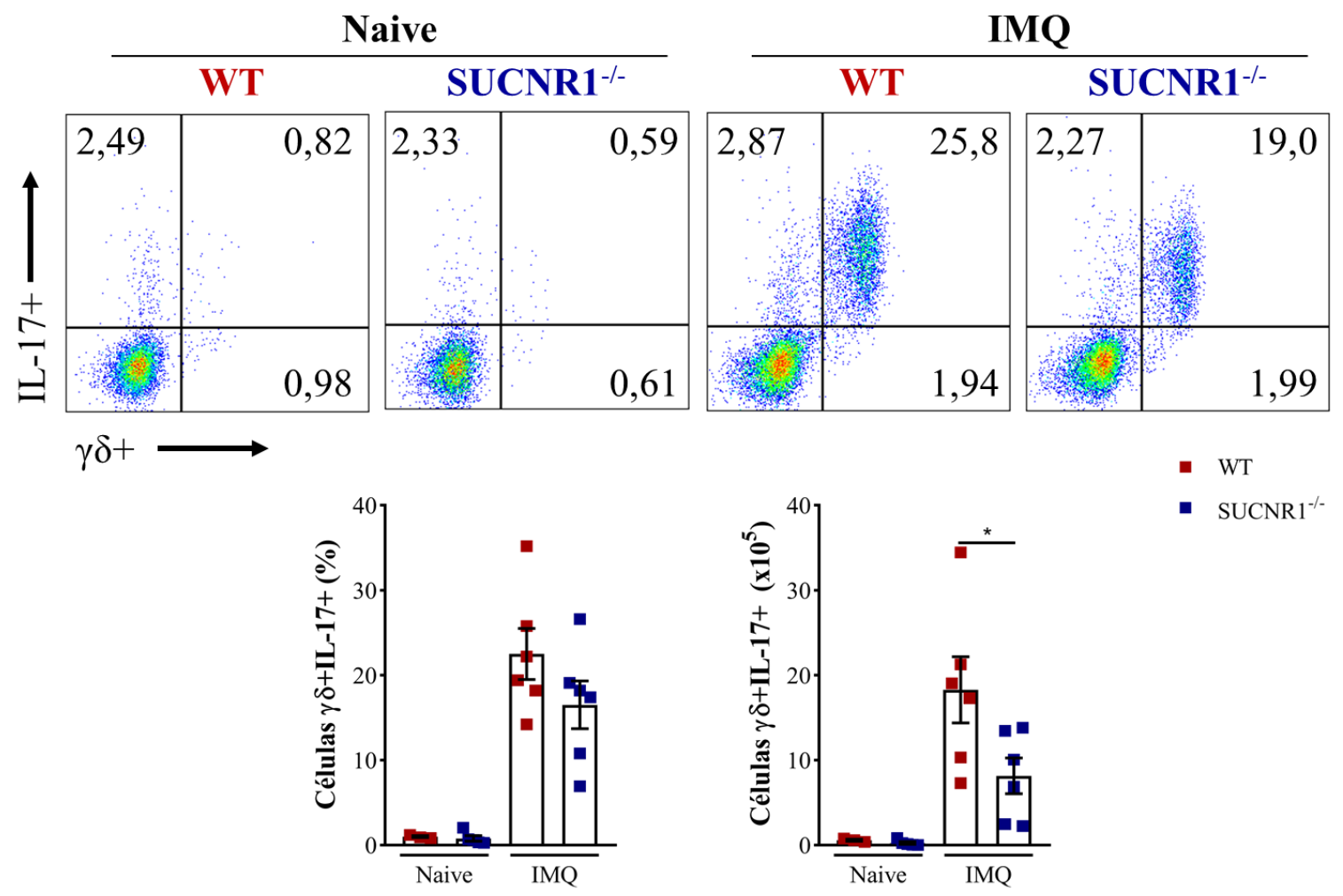

Figura 11. Células $T \gamma \delta$ produtoras de IL-17 na ausência do Sucnr1 em modelo experimental de psoríase. Animais C57BL/6 (WT) e deficientes para Sucnr1 (SUCNR1 ${ }^{-/}$) foram tratados ou não com $3 \mathrm{mg}$ de IMQ a 5\% topicamente durante seis dias. A suspensão celular dos linfonodos drenantes do dorso (dLNs) foi obtida e marcadas com probe de viabilidade (viadye) (APC.Cy7). Os dotplots foram pre-gateados em SSC-A/H, SSC-A/FSC-A e viadye negativo. A população de células $\mathrm{T} \gamma \delta$ produtoras de IL-17 marcadas com anti- $\gamma \delta$ (BV421) e anti-IL-17 (PE). Os gráficos apresentam média \pm SEM. *p $<0,05$ foi considerado estatisticamente significante

\subsection{O Sucnr1 contribui para expressão de citocinas inflamatórias na pele e no soro de animais induzidos com IMQ}

Vimos que a ausência do Sucnr1 resultou em menor produção de Il-17A nos dLNs da pele, por isso, verificamos na pele e no soro dos animais a produção de IL-17A, IL-23, necessária para manutenção de células produtoras de Il-17A e IL-1 $\beta$, produzida por queratinócitos e macrófagos ativados. Realizamos a coleta de pele no dia três para qRT-PCR e coletamos pele e soro dos animais no dia seis para realização de ELISA. Observamos que em animais deficientes para o receptor, a expressão de IL-23, de Il17, IL-17, Ill $\beta$ e IL-1 $\beta$ estão reduzidas na pele e no soro de animais SUCNR1 ${ }^{-/}$quando comparados aos animais WT (Figura 12), sugerindo que o Sucnr1 contribui para modulação de citocinas inflamatórias no local da lesão induzida por IMQ e sistemicamente. 
- WT

- $\mathrm{SUCNR}^{-1-}$
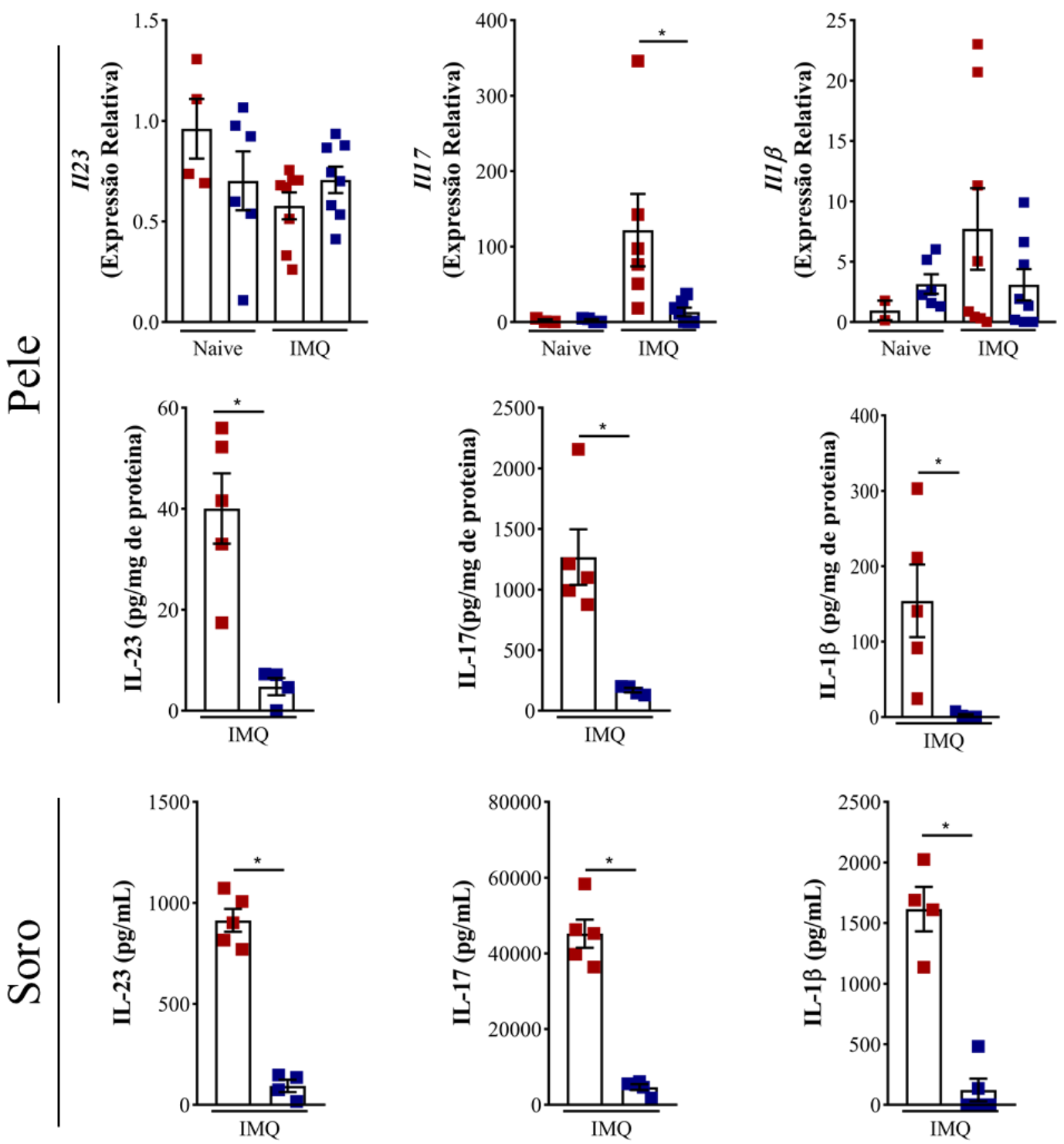

Figura 12. Citocinas inflamatórias na pele e no soro de animais na psoríase experimental. Animais C57BL/6 (WT) e deficientes para Sucnr1 $\left(\mathrm{SUCNR}^{-/}\right)$foram tratados ou não com 3 mg de IMQ a 5\%. No dia 3, parte da pele do dorso dos animais foi coletada, RNA extraído e convertido para realização de qRT-PCR para Gapdh, Il23, Ill7 e Ill $\beta$. A expressão é relativa ao Gapdh. No dia 6, foi realizado ELISA da pele e do soro para IL-23, IL-17 e IL-1 $\beta$. Os gráficos apresentam média \pm SEM. ${ }^{*} \mathrm{p}<0,05$ foi considerado estatisticamente significante.

\subsection{O Sucnr1 é majoritariamente expresso por células não-hematopoiéticas}

Em conjunto, os resultados obtidos até o momento vão de acordo com nossa hipótese inicial de que o Sucnr1 seria expresso por DCs, e nas quais a sua expressão seria importante para ativação e migração destas para os dLNs, onde induziriam a expansão de células produtoras de IL-17 , citocina que na pele ativam queratinócitos induzindo a proliferação e 
ativação exacerbada dos queratinócitos induzidas pela IL-17A resultando em maior expressão de marcadores de ativação, maior espessura da epiderme por hiperqueratose, acantose, paraqueratose e maior espessura da derme por edema e contribuiria para aumento no infiltrado inflamatório e ativação de células no local. Por este motivo, decidimos investigar a expressão do Sucnrl por células dendríticas de origem hematopoiética na pele psoriática, uma vez que não detectamos a expressão do Sucnrl nos dLNs.

Para tal, utilizamos animais reporter para CD11c, nos quais o gene Itgax é associado à proteína verde fluorescente (eGFP) e induzimos o protocolo de tratamento com IMQ na orelha durante quatro dias, iniciando no dia zero e encerrando no dia três, quando coletamos a orelha e processamos a pele até a obtenção da suspensão celular que foi marcada com probe de viabilidade e com anticorpo anti-CD45, direcionada a FACs (fluorescence activated cellsorting) de células CD45+eGFP negativas ou positivas e extraímos mRNA para realização de qRT-PCR para avaliarmos a expressão de Sucnrl por estas células (Figura 13A). Observamos que a maior parte da expressão do Sucnrl não é por células dendríticas (Figura 13B).

Como a expressão do receptor entre leucócitos é maior entre células que não são as dendríticas, decidimos investigar em qual compartimento celular o Sucnr1 é mais expresso, se entre células de origem hematopoiéticas ou de origem não-hematopoiéticas. Realizamos o protocolo de tratamento com IMQ em animais WT até o dia 3, quando foi realizada a coleta da pele para obtenção da suspensão celular, que foi marcada com probe de viabilidade e com anticorpo anti-CD45. Foi realizado sorting de células CD45- e CD45+, extração de mRNA e realização de qRT-PCR para avaliação da expressão de Sucnrl (Figura 14A). Observamos que o Sucnr1 fora majoritariamente expresso por células CD45-, de origem não-hematopoiéticas que seriam residentes da pele (Figura 14B) e não por células CD45+, de origem hematopoiéticas. É importante destacar que observamos que o Sucnr1 também foi expresso por células hematopoiéticas, porém em menor escala por estas células. 


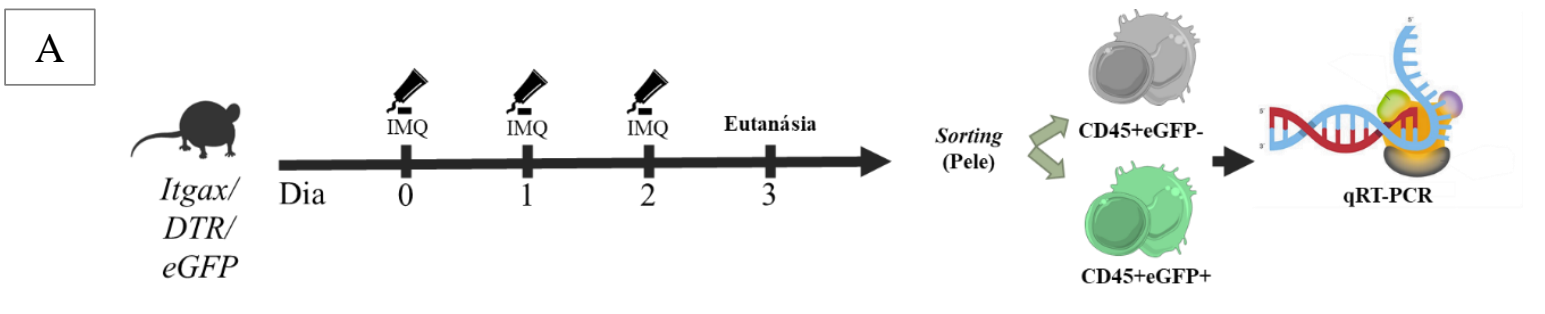

B

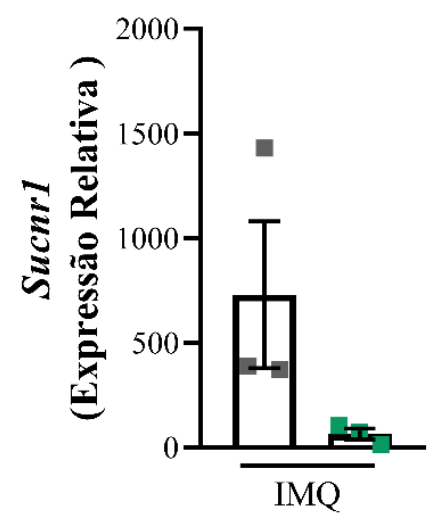

- eGFP-

- $\mathrm{eGFP}+$

Figura 13. Expressão de Sucnr1 em células hematopoiéticas e não-hematopoiéticas na pele psoriática. Animais Itgax/DTR/eGFP foram tratados ou não com $3 \mathrm{mg}$ de IMQ a 5\% topicamente durante 3 dias (A). A pele da orelha dos animais foi coletada no dia 3 e a suspensão celular marcada com probe de viabilidade (viadye) (APC.Cy7) e anti-CD45 (APC). O RNA foi extraído e convertido para realização de qRT-PCR para Gapdh e Sucnrl. A expressão é relativa ao Gapdh. O gráfico apresenta média \pm SEM. *p<0,05 foi considerado estatisticamente significante.

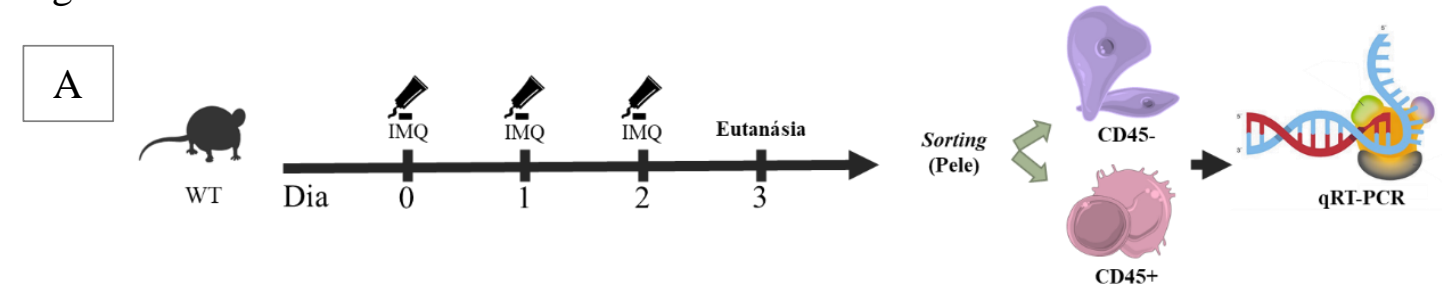

\section{B}

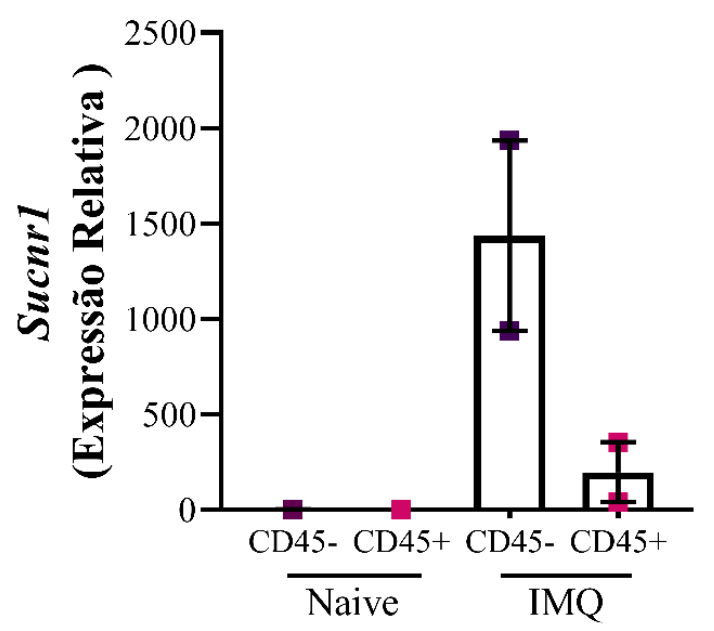

Figura 14. Expressão de SUCNR1 em células hematopoiéticas e não-hematopoiéticas na pele psoriática. Animais C57BL/6 (WT) foram tratados ou não com $3 \mathrm{mg}$ de IMQ a 5\% topicamente durante 3 dias (A). A pele da orelha dos animais foi coletada no dia 3 e a suspensão celular marcada com probe de viabilidade (viadye) (APC.Cy7) e anti-CD45 (APC). O RNA foi extraído e convertido para realização de qRT-PCR para Gapdh e Sucnrl. Cada ponto representa 
um pool de 3 ou 4 animais. A expressão é relativa ao Gapdh. O gráfico apresenta média \pm SEM. $* \mathrm{p}<0,05$ foi considerado estatisticamente significante.

\subsection{A expressão de Sucnr1 por células não-hematopoiéticas é biologicamente mais relevante para desenvolvimento da psoríase experimental}

Para verificar se a expressão do receptor por células não-hematopoiéticas seria biologicamente mais relevante para imunopatologia da psoríase experimental induzida pelo tratamento com IMQ do que por células de origem hematopoiéticas, optamos por realizar um ensaio de quimera no qual a medula óssea de camundongos WT e SUCNR1 ${ }^{-1-}$ foi completamente depletada através de irradiação com 7gy e após 24 horas tais animais foram reconstituídos com medula óssea de animais WT ou SUCNR1 ${ }^{-1}$. Após dois meses do transplante induzimos o protocolo de psoríase experimental conforme esquematizado (Figura 15A).

Um grupo de animais WT recebeu MO de animais WT $(\mathrm{WT} \rightarrow \mathrm{WT}$ ), outro grupo de animais WT recebeu MO de animais $\mathrm{SUCNR}^{-{ }^{--}}\left(\mathrm{SUCNR}^{-/-} \rightarrow \mathrm{WT}\right)$, animais $\mathrm{SUCNR} 1^{-/}$ receberam $\mathrm{MO}$ de animais $\mathrm{SUCNR}^{-/-}\left(\mathrm{SUCNR}^{-/-} \rightarrow \mathrm{SUCNR}^{-/-}\right)$, animais $\mathrm{SUCNR}^{-/-}$ receberam MO de animais $\mathrm{WT}\left(\mathrm{WT} \rightarrow \mathrm{SUCNR}^{-/-}\right)$e dois grupos de animais WT e SUCNR $1^{-/-}$ não radiados foram utilizados como controles naive. Desta forma, possuímos animais quimera com células residentes WT ou SUCNR1 $1^{-/}$e células hematopoiéticas SUCNR1 ${ }^{-/-}$ou WT. Por se tratar de um ensaio longo e raro, o tratamento foi realizado no dorso e na orelha dos animais.

Em animais receptores selvagens, independente de as células hematopoiéticas serem provenientes de animais WT ou SUCNR $1^{-/}$, WT $\rightarrow$ WT e SUCNR1 $1^{-/} \rightarrow$ WT, a espessura da pele induzido por IMQ é significativamente maior do que o observado em animais receptores SUCNR $1^{-/}$, independente de terem sido reconstituídos com células hematopoiéticas de animais $\mathrm{SUCNR}^{-/-}$ou WT $\left(\mathrm{SUCNR}^{-/-} \rightarrow \mathrm{SUCNR}^{-{ }^{--}}\right.$e WT $\left.\rightarrow \mathrm{SUCNR}^{-/-}\right)($Figura 15B$)$, o que foi corroborado pela maior presença de eritema e descamação nas orelhas dos animais (Figura 15C). Deste modo, nosso achado sugere que a função do Sucnr1 na promoção da psoríase se deu de maneira dependente de sua expressão em células de origem não-hematopoiética, uma vez que o impacto de sua expressão em células de origem hematopoiéticas foi irrelevante.

Animais com o mesmo receptor, que possuem células residentes com mesmo genótipo, $\mathrm{WT} \rightarrow \mathrm{WT}$ e $\mathrm{SUCNR}^{-/-} \rightarrow \mathrm{WT}$, bem como $\mathrm{SUCNR}^{-/-} \rightarrow \mathrm{SUCNR}^{-/-}$e WT $\rightarrow \mathrm{SUCNR}^{-1-}$, apresentaram fenótipos semelhantes, sugerindo não apenas que a expressão do Sucnr1 por células de origem não-hematopoiética é biologicamente mais relevante para o desenvolvimento de psoríase experimental, como também que a expressão de Sucnr1 por células hematopoiéticas não contribui para imunopatologia induzida por IMQ. 

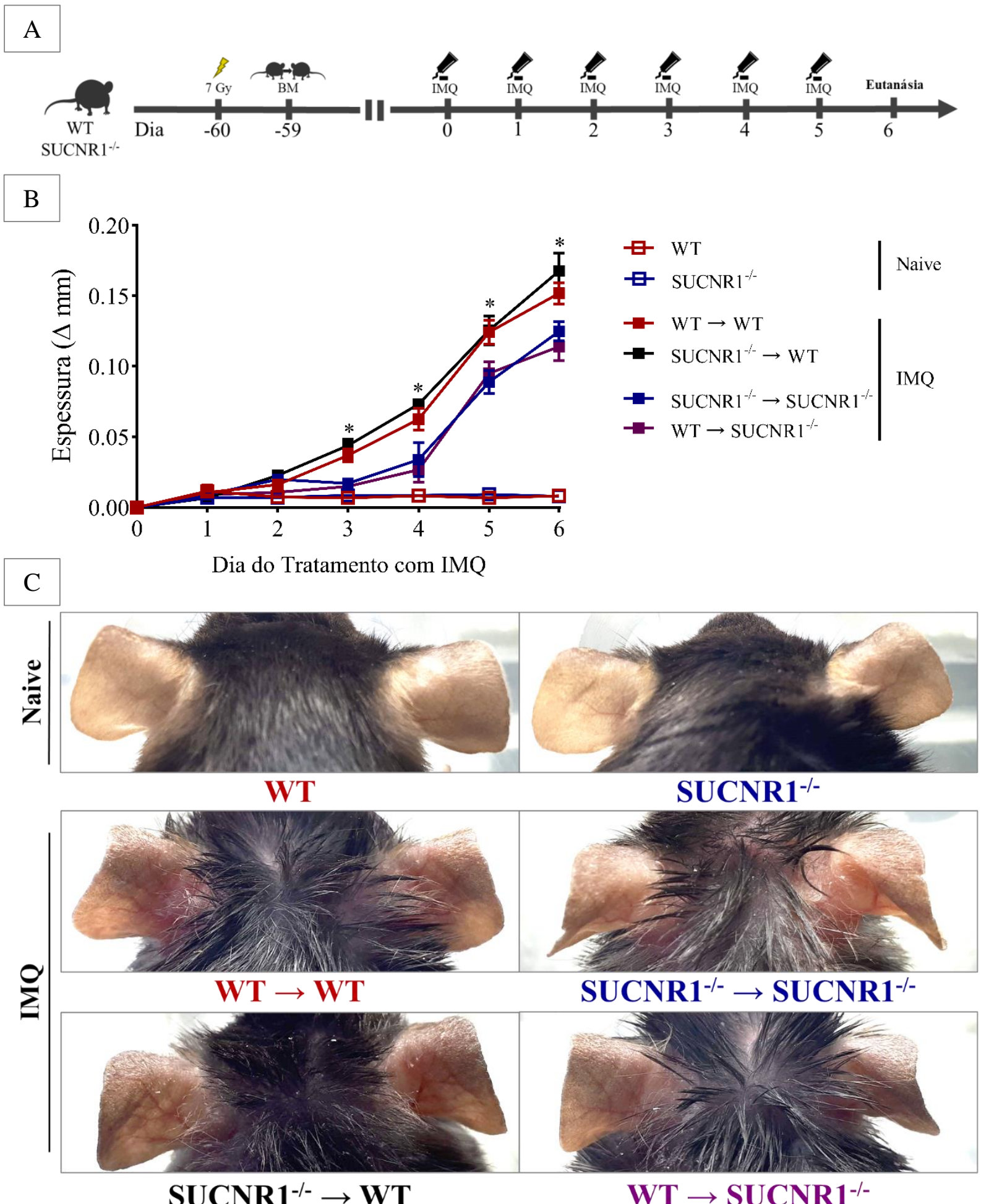

Figura 15. Repercussão do Sucnr1 na espessura, eritema e descamação da pele de animais quimera tratados com IMQ. Animais C57BL/6 (WT) e deficientes para Sucnr1 (SUCNR1 ${ }^{-/}$) irradiados e transplantados com medula óssea de animais WT ou SUCNR $1^{-/}$, após dois meses foram tratados ou não com $3 \mathrm{mg}$ de IMQ a 5\% topicamente durante seis dias $(\mathbf{A})$. A espessura da pele da orelha dos animais foi mensurada diariamente com paquímetro para obtenção do delta relativo ao primeiro dia $(\mathbf{B})$ e fotografadas no dia $6(\mathbf{C})$. O gráfico apresenta média \pm SEM. $* p<0,05$ foi considerado estatisticamente significante. 


\subsection{O Sucnr1 expresso por células de origem não-hematopoiéticas na pele contribui para} o aumento de hiperqueratose, acantose e paraqueratose na psoríase experimental

Considerando que a expressão do Sucnr1 por células de origem não-hematopoiéticas na pele esteve mais relacionada com a indução de espessamento, eritema e descamação durante a indução da psoríase experimental, investigamos se esse achado corroboraria com a expressão de K17 nos animais quimera. Assim, observamos uma tendência de aumento de expressão de K17 nos animais receptores WT em relação aos animais receptores SUCNR1 ${ }^{-/-}$(Figura 16). Diferente de todos os protocolos nos quais coletamos material para extração de RNA, neste ensaio só realizamos coleta no dia seis por se tratar de um experimento grande e longo, com um elevado número de camundongos, por isso possivelmente perdemos o pico da expressão de mRNA de K17 nestes animais.

$\mathrm{Na}$ histologia observamos maior presença de hiperqueratose, acantose e paraqueratose nos receptores WT, independente de possuírem leucócitos de doadores WT ou SUCNR1 $1^{--}$ (Figura 17), corroborando com os achados anteriores e reforçando que a expressão do Sucnr1 por células de origem não-hematopoiética apenas seria relevante na psoríase experimental.

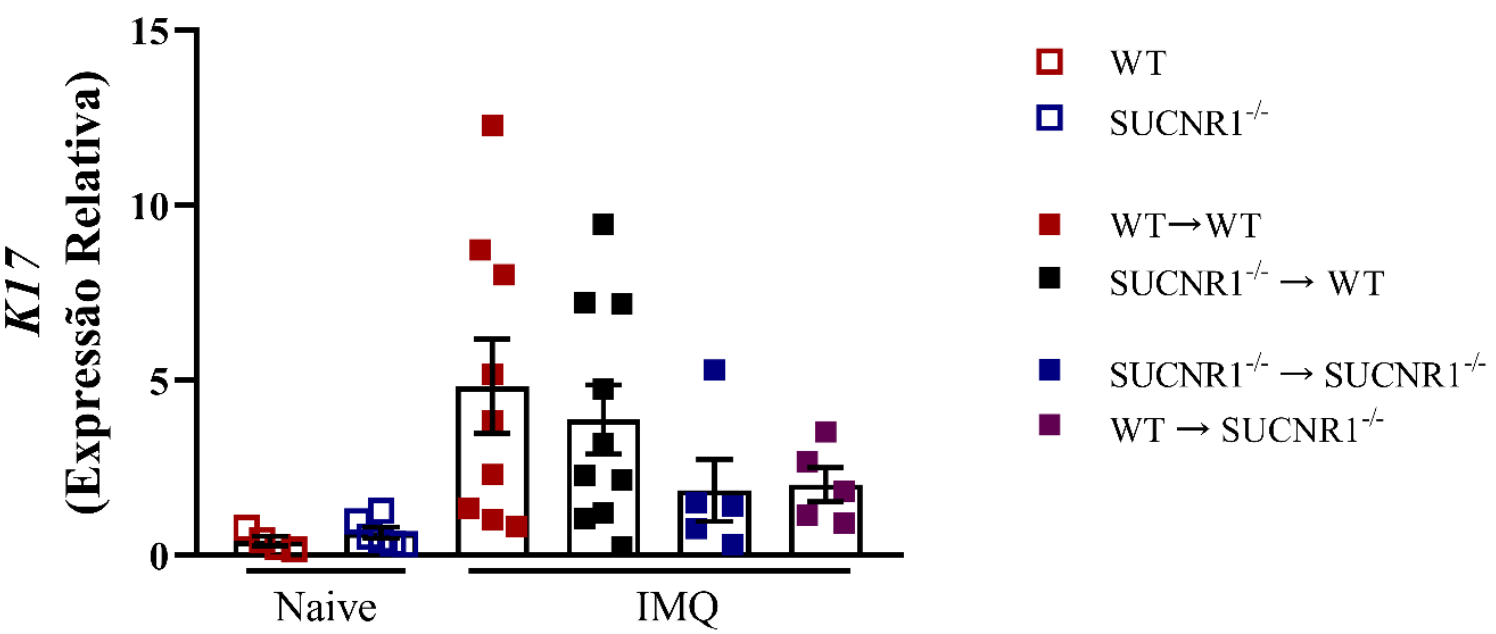

Figura 16. Expressão de $K 17$ em animais quimera tratados com IMQ. Animais C57BL/6 (WT) e deficientes para Sucnr1 (SUCNR1 ${ }^{-/}$) irradiados e transplantados com medula óssea de animais WT ou SUCNR ${ }^{-/}$, após dois meses foram tratados ou não com $3 \mathrm{mg}$ de IMQ a $5 \%$ topicamente durante seis dias. Parte da pele da orelha foi coletada, RNA extraído e convertido para realização de qRT-PCR para Gapdh e K17. A expressão é relativa ao Gapdh. O gráfico apresenta média \pm SEM. $* \mathrm{P}<0,05$ foi considerado estatisticamente significante. 


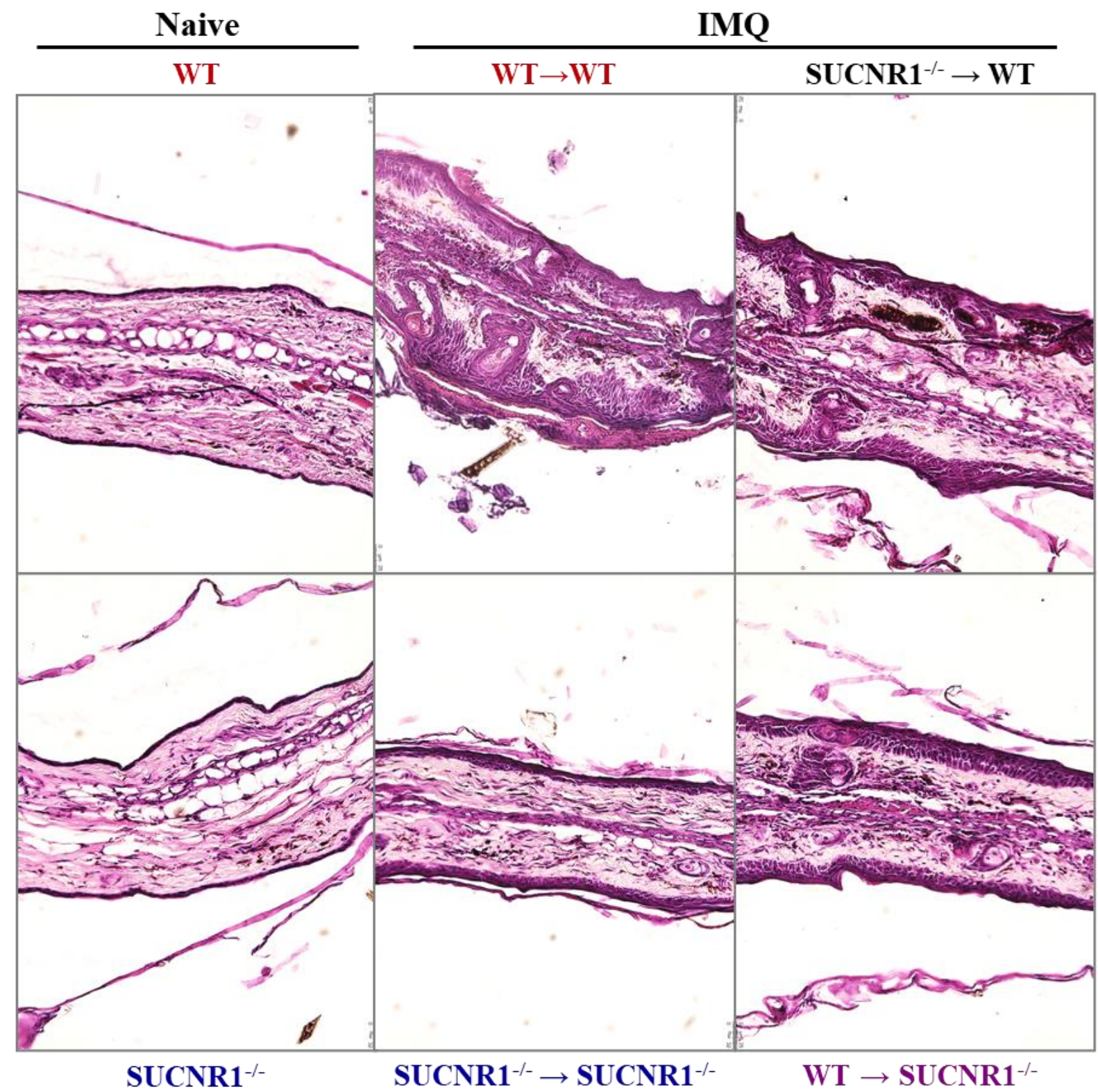

Figura 17. Histologia da orelha de animais quimera tratados com IMQ. Animais C57BL/6 (WT) e deficientes para Sucnr1 (SUCNR1 ${ }^{-/}$) irradiados e transplantados com medula óssea de animais WT ou SUCNR1 ${ }^{-/}$, após dois meses foram tratados ou não com $3 \mathrm{mg}$ de IMQ a $5 \%$ topicamente durante seis dias. A pele da orelha dos animais foi coletada no dia 6 para cortes histológicos e coloração com H\&E. Objetiva de 10x.

\subsection{O Sucnr1 é expresso por queratinócitos}

Sabendo que o Sucnr1 expresso por células não-hematopoiéticas esteve mais relacionado com o desenvolvimento da psoríase experimental, questionamos se os queratinócitos, as células mais abundantes e que compõem $90 \%$ da epiderme, os quais as disfunções de ativação e proliferação caracterizam a psoríase bem como seu modelo experimental, apresentariam elevada expressão do Sucnrl durante a psoríase experimental. Para tanto, realizamos um ensaio de hibridização in situ no qual o mRNA do Sucnrl foi marcado 
com uma probe fluorescente e em seguida foi realizado imunofluorescência para a K17 (Figura 18). Observamos que a expressão do Sucnrl se concentra em regiões da epiderme e foi positivamente modulado em regiões nas quais a K17 também é expressa.

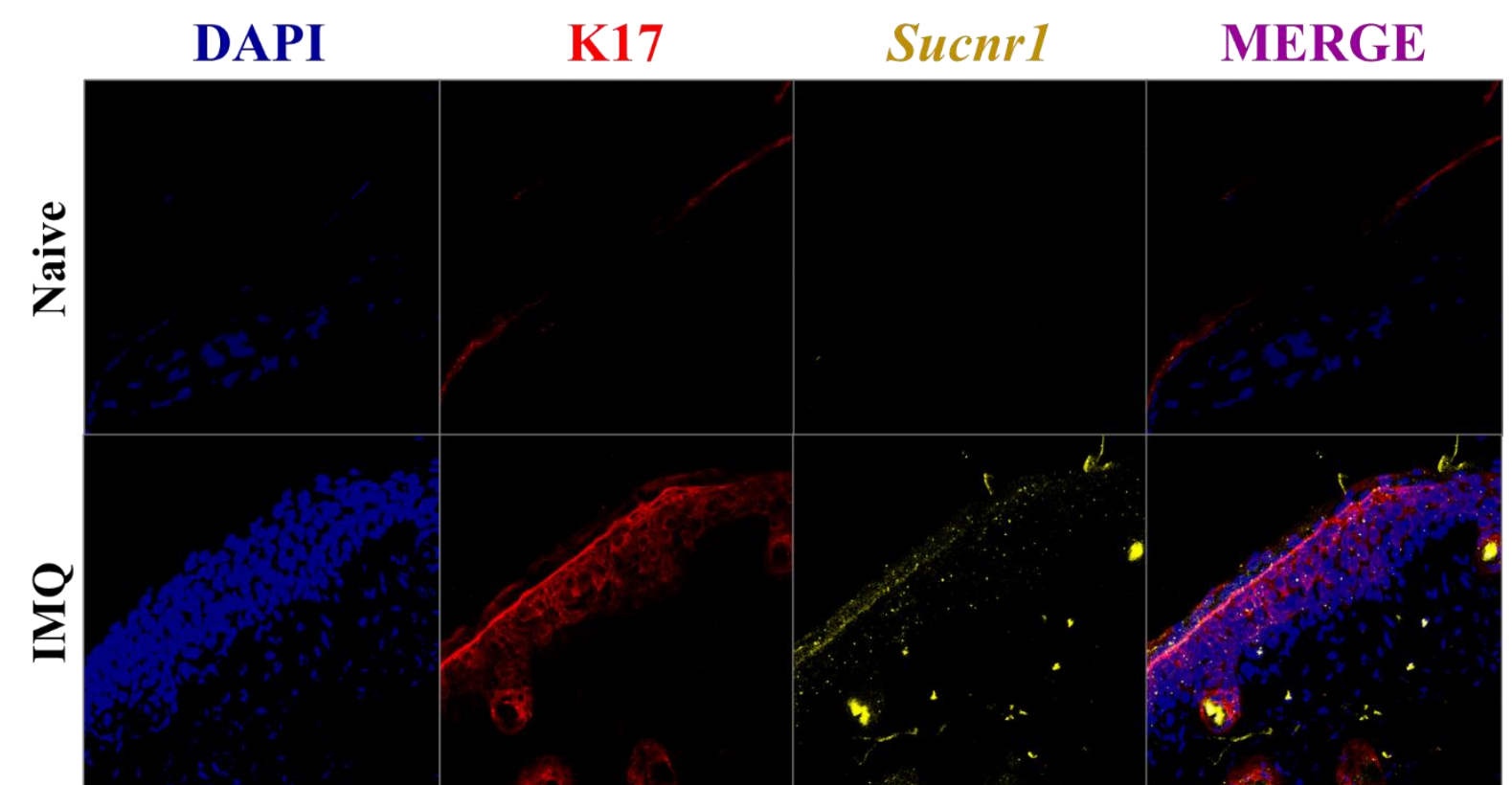

Figura 18. Expressão do Sucnr1 por queratinócitos. Animais C57BL/6 (WT) foram tratados ou não com $3 \mathrm{mg}$ de IMQ à $5 \%$ topicamente durante três dias. Realizou-se RNAScope para Sucnr1 (amarelo) e imunofluorescência para K17 (vermelho) e DAPI (azul).

Para confirmar tais achados, realizamos imunofluorescência para S100A9, uma alarmina sabidamente produzida por queratinócitos e leucócitos ativados na pele, especialmente por DCs durante a psoríase experimental (Melo, 2017) e para Sucnr1 (Figura 19). Observamos que a expressão proteica do Sucnr1 se concentrou na epiderme, onde colocalizou-se com a expressão de S100A9 e que ainda, na derme onde o S100A9 é expresso principalmente por células dendríticas, o receptor não está colocalizado com o este, reforçando que as células de origem não-hematopoiéticas que expressam o receptor são os queratinócitos e que a maioria dos leucócitos que expressam o Sucnr1 não são DCs. 


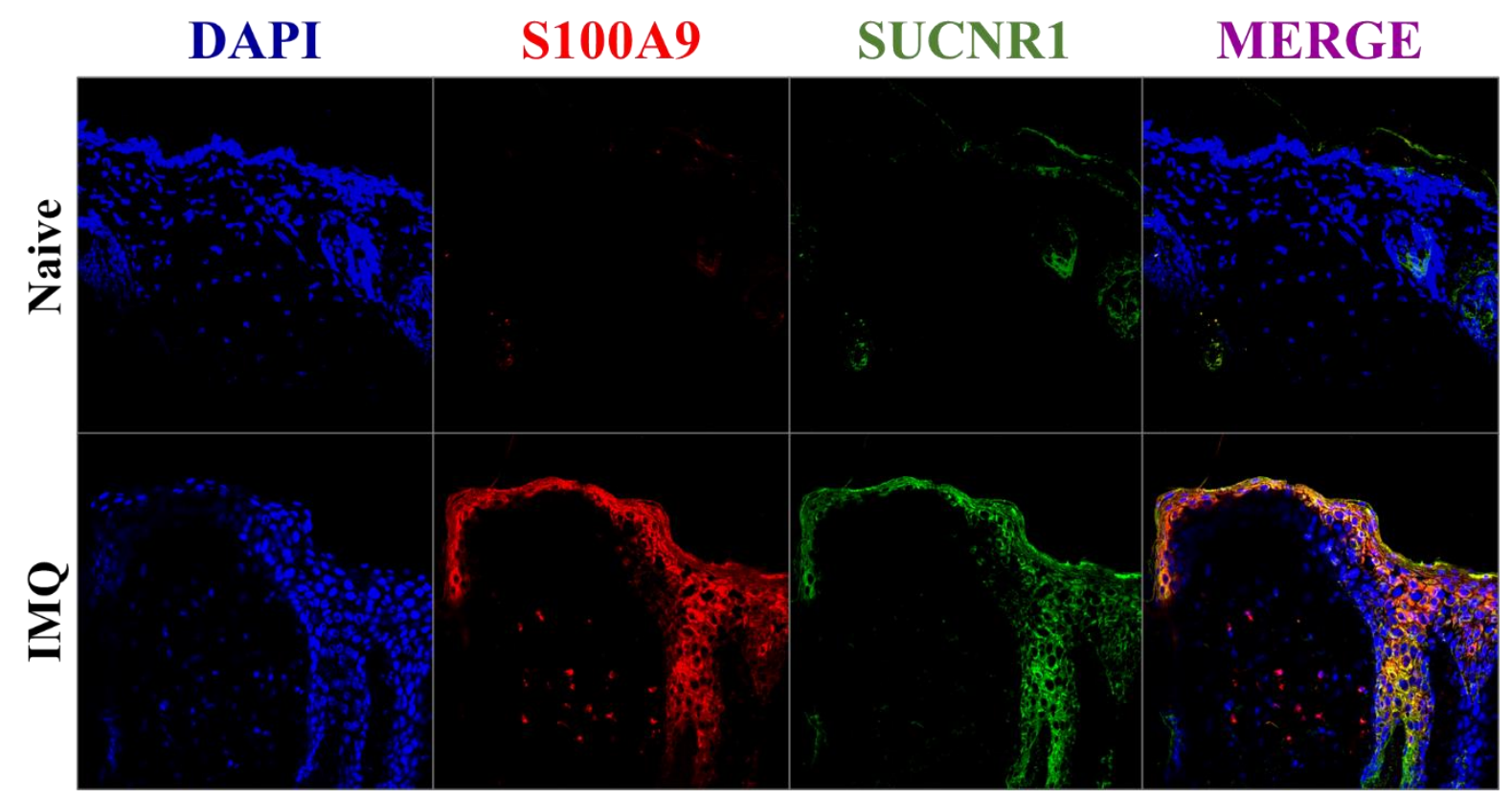

Figura 19. Expressão do SUCNR1 por queratinócitos. Animais C57BL/6 (WT) foram tratados ou não com $3 \mathrm{mg}$ de IMQ à 5\% topicamente durante seis dias. Foi realizado imunofluorescência para S100A9 (vermelho), Sucnr1 (verde) e DAPI (azul).

\subsection{O tratamento tópico com succinato induz aumento na espessura da pele}

Tendo em vista que os queratinócitos apresentam uma expressão basal de Sucnr1 na pele de animais WT e que estas células compõem cerca de $90 \%$ da epiderme, questionamos se o tratamento tópico de animais com o ligante do receptor seria capaz de desregular de alguma maneira a homeostasia da pele. Realizamos então um ensaio no qual um creme com $3 \%$ de succinato foi aplicado topicamente no dorso dos animais durante sete dias, e como controles deste tratamento, aplicamos apenas o veículo deste creme em um grupo de animais, além disso, realizamos também a indução com IMQ como um controle positivo de disfunção da homeostasia (Figura 20A). Observamos que o tratamento com succinato per se resultou, de maneira progressiva no aumento da espessura da pele dos animais (Figura 20B). Este achado sugere que os níveis basais de expressão do Sucnr1 foram capazes de alterar a homeostasia da pele. Apesar de não termos observado descamação e eritema, não observamos a vascularização como nos animais naive ou tratados com veículo (Figura 20C), sugerindo que o espessamento que observamos se deve à um aumento da epiderme. 

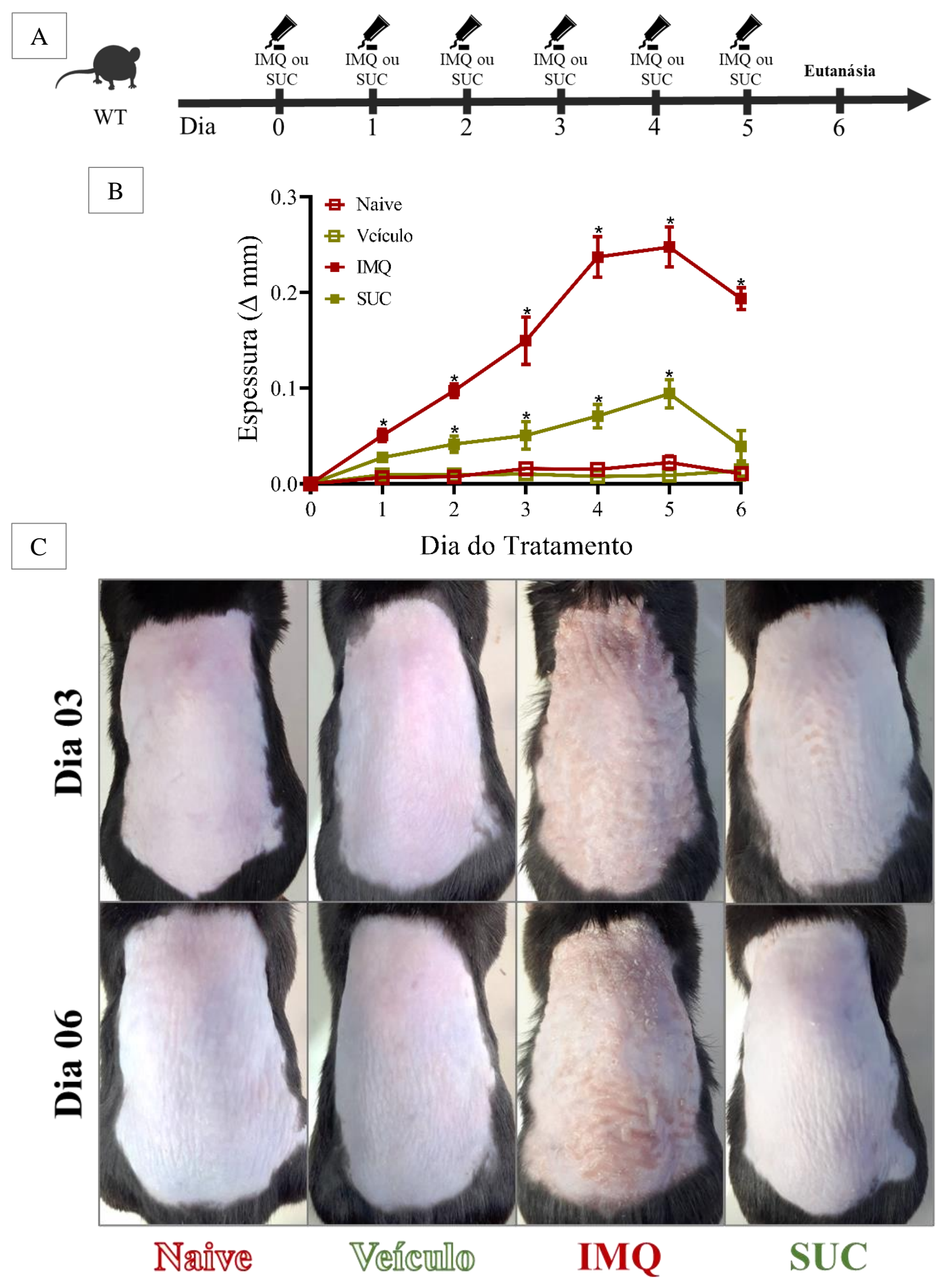

Figura 20. Espessura, eritema e descamação na pele de animais após tratamento tópico com creme de succinato. Animais C57BL/6 (WT) foram tratados ou não com veículo, $3 \mathrm{mg}$ de IMQ a 5\% ou com 1,8 mg de succinato a 3\% topicamente durante seis dias (A). A espessura da pele dos animais foi mensurada diariamente com paquímetro para obtenção do delta relativo ao primeiro dia, o dia 0 (B). O dorso dos animais foi fotografado nos dias 3 e 6 (C). O gráfico apresenta média \pm SEM. $*$ p $<0,05$ foi considerado estatisticamente significante. 
Para confirmar se o espessamento da pele observado nos animais tratados com succinato se deu via sinalização do succinato em seu receptor, realizamos um segundo ensaio tratando animais SUCNR $1^{-/-}$com veículo e o creme de succinato durante sete dias (Figura 21A) e não observamos aumento na espessura da pele dos animais tratados com succinato (Figura 21B), alteração na pele destes (Figura 21C), sugerindo que de fato, o que observamos no ensaio anterior foi resultante da sinalização do succinato em seu receptor Sucnr1 e não de ações independentes.

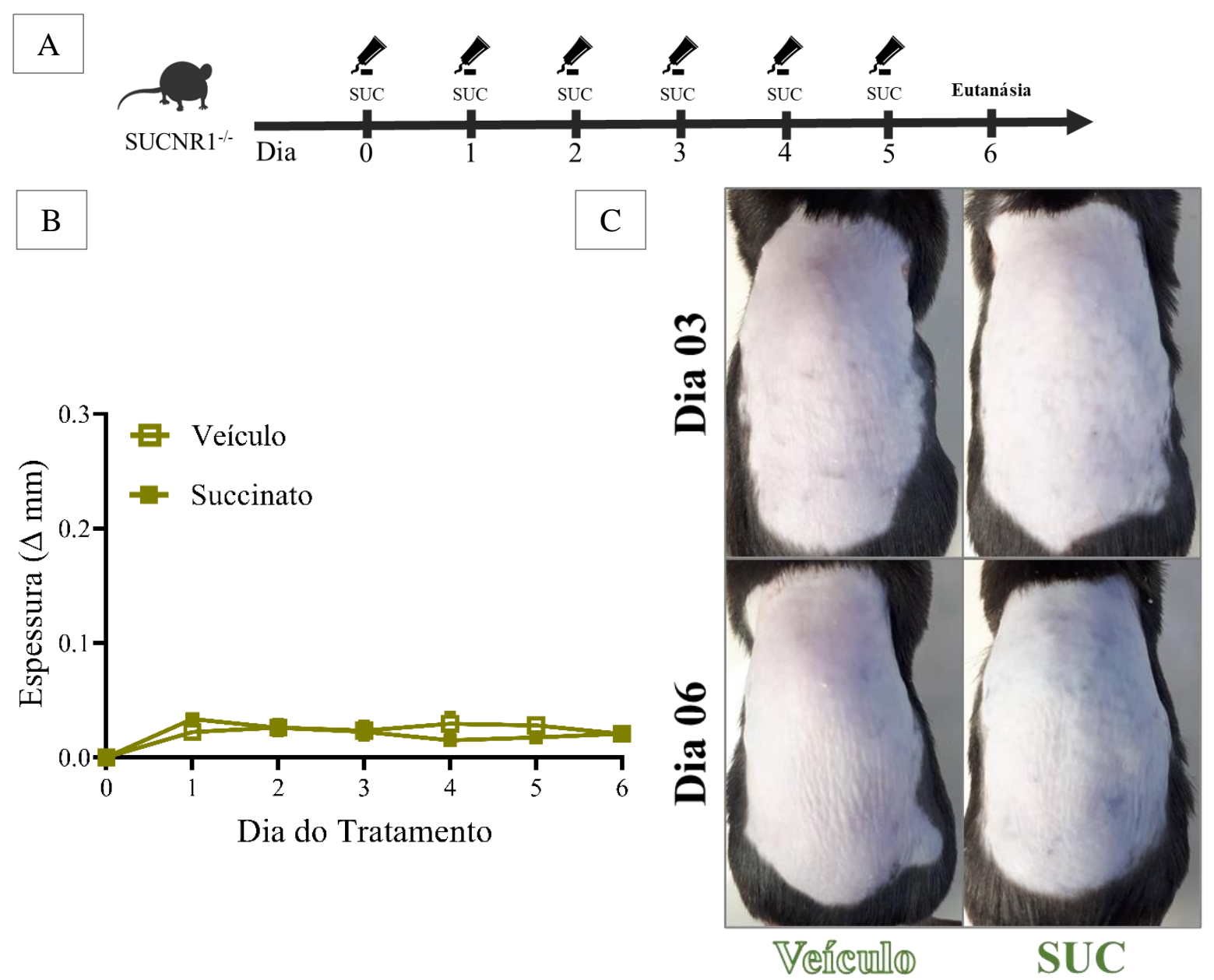

Figura 21. Espessura, eritema e descamação da pele de animais SUCNR1 ${ }^{-/-}$tratados com $^{-1}$ succinato. Animais deficientes para Sucnr1 (SUCNR1 ${ }^{-/}$) foram tratados ou não com veículo ou com 1,8 mg de succinato a $3 \%$ topicamente durante seis dias (A). A espessura da pele dos animais foi mensurada diariamente com paquímetro para obtenção do delta relativo ao primeiro dia, o dia $0(\mathbf{B})$. O dorso dos animais foi fotografado nos dias 3 e $6(\mathbf{C})$. O gráfico apresenta média \pm SEM. ${ }^{*} \mathrm{p}<0,05$ foi considerado estatisticamente significante. 


\section{DISCUSSÃO}

A psoríase é uma doença inflamatória de caráter crônico que não possui cura e os tratamentos disponíveis são pouco específicos, ainda que os imunobiológicos sejam eficazes podem resultar em efeitos adversos indesejados além de possuírem elevado custo (Griffiths et al., 2017; Boehncke, Pshon, 2015). Considerando que diversos metabólitos são modulados durante um processo inflamatório, como o succinato no fluido sinovial de pacientes com artrite reumatoide, que o succinato possui como receptor o Sucnr1 é expresso principalmente por DCs no contexto de artrite e que na psoríase as DCs são primordiais para desenvolvimento e manutenção da doença (Kim et al., 2014; Saraiva et al., 2018), questionamos se a expressão do Sucnr1 nas DCs contribuiria para o desenvolvimento da psoríase podendo assim se tornar um interessante alvo terapêutico.

Saraiva et al. (2018) demonstrou em modelo de artrite reumatoide aumento na expressão proteica do Sucnr1 por DCs nos dLNs da articulação patelofemoral, assim iniciamos este estudo investigando sua expressão a nível de mRNA em dLNs da orelha, os linfonodos cervicais. De maneira surpreendente a expressão do receptor nos dLNs é baixa e o tratamento com IMQ não induz ou aumenta sua expressão neste órgão (Figura 5B), mas na pele é expresso em níveis basais e aumenta significativamente quando no tratamento com IMQ (Figura 5C). Na artrite reumatoide, o Sucnr1 é expresso por DCs e por este motivo é observado nos dLNs, assim, estes resultados iniciais sugerem que mecanismos inerentes à pele psoriática induzem a expressão do receptor, podendo esse ser um importante componente da fisiopatologia da doença.

De maneira semelhante ao que ocorre na psoríase, o IMQ é reconhecido por TLR 7 e 8 de pDCs, induz produção de interferons do tipo I que ativam dDCs, estas migram para dLNs e apresentam um antígeno desconhecido para células T naive induzindo a polarização e expansão de células produtoras de IL-17 que na pele ativa queratinócitos induzindo a ativação e proliferação exacerbada dos mesmos, como resultado disso observa-se acantose, hiperqueratose e paraqueratose (Fits et al., 2009; Moos et al., 2019). Tal efeito do imiquimode é observado tanto na pele de humanos quanto na pele de camundongos (Moos et al., 2019). Visto que a literatura descreve a expressão do Sucnr1 por DCs, questionamos se a psoríase experimental se desenvolveria na ausência deste e observamos que o tratamento com IMQ em animais $\mathrm{SUCNR}^{-/-}$resultou em menor edema de pele, eritema e descamação (Figuras 6B e 6C), além disso a pele apresentou menos acantose, hiperqueratose, paraqueratose e infiltrado celular (Figura 8) de maneira ainda mais acentuada no sexto dia do protocolo de tratamento, sugerindo que o Sucnr1 estaria envolvido nos mecanismos patológicos da psoríase. 
Este estudo apresenta dados com animais nocautes totais (SUCNR $1^{-/}$), por isso a ausência do receptor poderia implicar em alterações fisiológicas que poderiam impactar nos resultados observados, uma vez que o mesmo é expresso por outras células, como os adipócitos (McCreath et al. 2015; Tilg, Moschen, 2006). Para retirarmos este viés do trabalho avaliamos se os animais SUCNR1 ${ }^{-/-}$apresentariam alterações de perda e recuperação de peso corpóreo durante a indução com IMQ, no entanto não observamos nenhuma alteração nesse padrão entre os grupos experimentais (Figura 7).

Apesar de ter sido descrito que o IMQ induz a expressão de TLR-7 em cultura primária de queratinócitos (Li et al., 2013), a principal forma de ativação de queratinócitos pelo IMQ é independente de TLR (Flutter, Nestle, 2013) e ocorre mais intensamente de maneira indireta, via indução de IL-17 (Furue et al., 2020). A intensa proliferação de queratinócitos é uma das principais características da psoríase, essas células expressam K17 quando neste estado, tal queratina é ausente em condições homeostáticas, assim, a expressão de K17 é utilizada como marcador da psoríase (Leigh et al., 1995). A lipocalina 2 (LCN2) é uma citocina expressa por queratinócitos em processo de diferenciação, sendo também utilizada como marcador da pele psoriática (Mallbris et al., 2002). Com base nessas informações, avaliamos a expressão gênica de $K 17$ e de Lcn2, assim como a expressão proteica de K17 na pele dos animais. Ambas se encontram elevadas na pele psoriática dos camundongos WT, mas apresentaram-se acentuadamente menores na pele psoriática dos animais SUCNR $1^{-/-}$(Figura 9A, B), sugerindo assim que o Sucnr1 estaria envolvido direta ou indiretamente na indução de IL-17, contribuindo assim para disfunção dos queratinócitos na psoríase.

A IL-17 é a principal citocina envolvida na patogênese da psoríase, ativando diretamente osqueratinócitos induzindo proliferação e maturação destes, atuando como quimioatraente de neutrófilos e no ciclo de ativação que resulta na cronicidade da doença (Blauvelt, Chiricozzi, 2018). As principais fontes de IL-17 na pele são células T CD4+ e T $\gamma \delta+$, sendo as células T $\gamma \delta+$ maiores responsáveis pela produção de IL-17 na pele psoriática (Diane, Altomare, Reali 2016; Cai et al., 2011). Desta forma, avaliamos as populações de células $\alpha \beta$ e $\gamma \delta$ produtoras de IL-17 nos dLNs e observamos redução dessas populações em animais SUCNR $1^{-/-}$tratados com IMQ (Figura 10, 11), reforçando a ideia de que o Sucnr1 estaria envolvido na indução ou expansão dessas populações. Em seguida, quantificamos os níveis de IL-23, que é caracterizado como um mediador essencial para manutenção de células produtoras de IL-17 (Gaffen et al., 2014), citocina de grande importância no processo inflamatório associado à psoríase (Blauvelt, Chiricozzi, 2018), e os níveis de IL-1 $\beta$ produzida por queratinócitos e macrófagos ativados, conhecida pela contribuição para proliferação de células T $\gamma \delta$ e indução de IL-17 (Cai et al., 
2019). Verificamos redução nas expressões gênica e proteica dessas citocinas na pele e no soro de animais SUCNR1 ${ }^{-/}$(Figura 12), sugerindo assim que o Sucnr1 contribui para indução do processo inflamatório local e sistêmico na psoríase.

Rubic-Schneider e colaboradores demonstraram que o Sucnr1 é necessário para migração de células dendríticas imaturas da pele para os linfonodos drenantes de camundongos imunizados com toxoide tetânico. Além disso, foi demonstrado que o receptor atua na rejeição à enxertos alográficos de pele, sugerindo que o receptor seria expresso por células dendríticas imaturas e que induziriam processos inflamatórios na pele (Rubic-Schneider et al., 2008). Com suporte nesses dados, hipotetizamos que na psoríase a sinalização do succinato em seu receptor Sucnr1 em DCs desempenharia efeito quimiotáxico resultando na migração destas para dLNs onde induzem resposta imune adaptativa de células produtoras de IL-17. A redução de células $\mathrm{T} \alpha \beta$ e $\gamma \delta$ produtoras de IL-17 bem como redução no edema e infiltrado inflamatório na pele em animais SUCNR1 $1^{-/}$sugeriu que essa hipótese inicial estaria correta. Induzimos o protocolo de indução com IMQ em animais Itgax/DTR/eGFP e no terceiro dia realizamos sorting de células CD45+eGFP- e células CD45+/eGFP+ (Figura 13A). Surpreendentemente observamos que a expressão do Sucnrl ocorre principalmente em leucócito(s) não identificados, e não por células dendríticas (Figura 13). Em seguida repetimos o protocolo de sorting de células de origem não-hematopoiéticas (CD45-) e de origem hematopoiéticas (CD45+) seguido de qRTPCR para Sucnrl (Figura 14A) e para nossa surpresa observamos que o Sucnrl é principalmente expresso por células de origem não-hematopoiéticas (Figura 14B).

Como verificamos a expressão do Sucnrl tanto por células de origem nãohematopoiética como de origem hematopoiética, realizamos um ensaio de quimera para verificarmos se a expressão do receptor por qual população seria mais determinante na psoríase experimental e observamos que a presença do Sucnr1 em leucócitos é indiferente na psoríase, uma vez que os animais que possuíam células residentes $\mathrm{SUCNR} 1^{-/-}$apresentaram menos edema, eritema e descamação da pele do que animais que possuíam células residentes WT, independente de os leucócitos serem WT ou SUCNR1 ${ }^{-/-}$(Figura 15B, C) e reforçando esses achados, os animais que possuíam células residentes WT desenvolveram mais acantose, hiperqueratose, paraqueratose edema e apresentaram maior infiltrado inflamatório diante do não aparecimento destes parâmetros àqueles que possuíam células residentes SUCNR1 ${ }^{-/}$ (Figura 17). Este resultado sugere que a expressão do Sucnr1 por células não-hematopoiéticas contribui para o desenvolvimento da psoríase.

Os queratinócitos são as células mais abundantes da epiderme e a psoríase, bem como seu modelo experimental se caracterizam pela disfunção dessas células, logo, questionamos se 
não seriam os queratinócitos as células de origem não-hematopoiética que expressariam o Sucnr1, para tanto, realizamos um ensaio de hibridização in situ no qual verificamos que as células residentes da epiderme que expressam Sucnrl são os queratinócitos (Figura 18). Em seguida, para confirmar este achado realizamos imunofluorescência para o Sucnr1 e para S100A9, uma alarmina que na epiderme é produzida por queratinócitos (Melo, 2017; Wang et al., 2018) na qual constatamos que o receptor é expresso por queratinócitos (Figura 19). Estes resultados não contradizem o estudo, porém podem inserir a ideia de que no modelo de alotransplante realizado por Rubric et al (2008) a expressão de Sucnr1 por queratinócitos poderia contribuir também para rejeição ao enxerto.

Considerando o acúmulo de succinato no líquido sinovial de pacientes com artrite reumatoide e da importância de DCs na doença, tanto em pacientes como em modelos experimentais, Saraiva et al. (2018) investigou o papel do succinato e seu receptor no modelo de artrite induzida por antígeno (AIA) e verificaram que após a imunização dos animais com albumina sérica bovina (BSA) na capsula articular, observa-se acúmulo de DCs expressando Sucnr1 nos dLNs. Através de um ensaio de quimera, utilizando camundongos CD11c-DTR, nos quais as células dendríticas expressam o receptor da toxina diftérica, ocorrendo depleção destas após a inoculação da toxina, comprovou-se que no modelo de artrite induzida pela BSA a expressão de Sucnr1 por DCs é importante para migração destas para dLNs onde atuam na expansão células produtoras de IL-17 contribuindo assim para o processo inflamatório na articulação dos animais. Na psoríase experimental, a expansão de células produtoras de IL-17 nos dLNs e sua presença na pele estavam reduzidas na ausência de Sucnr1, o que associado aos resultados demonstrando a expressão do receptor por queratinócitos e ao fato de que na pele contribui para atividade inflamatória em resposta à indução com IMQ, sugere que via direta ou indireta o IMQ modula a expressão do Sucnr1 em queratinócitos que, por sua vez, induz de maneira indireta a expansão de células produtoras de IL-17.

Sabe-se que o succinato, assim como o IMQ, é importante para secreção de TNF e de IL-1 $\beta$ por células dendríticas derivadas da medula óssea (MoDC) e que macrófagos derivados de medula óssea não respondem ao estímulo com succinato (Rubic-Schneider et al., 2008). Verificamos que de fato a IL-1 $1 \beta$ está reduzida na pele de animais nocauteados para o Sucnr1 sugerindo que através da sinalização em seu receptor o succinato contribui para ativação de células da resposta imune inata. Em resposta à sinalização do Sucnr1 em queratinócitos, acreditamos que estes secretariam IL-1 $\beta$ contribuindo para a expansão de células $\mathrm{T} \gamma \delta$ e produção de IL-17 por células T $\alpha \beta$ e $\gamma \delta$, alimentando assim o loop inflamatório na pele psoriática e/ou que aumentaria a expressão de outros fatores inflamatórios, como a S100A9. 
Células da resposta imune em condições de homeostasia realizam fosforilação oxidativa para suprir a demanda energética. Em condições de estresse, tais como em processos inflamatórios, a via glicolítica se torna mais ativa como uma maneira de atender rapidamente à elevada demanda por energia. Nesse processo, o HIF-1 $\alpha$ é essencial para a indução de genes envolvidos na via glicolítica (Mills, O’Neill, 2014). É descrito que em alguns tipos de tumor o succinato se acumula na mitocôndria, no citosol e extracelularmente devido a interrupção do ciclo de Krebs, atuando na estabilização do HIF-1a (Selak et al., 2005). Além disso, foi demonstrado que em macrófagos o succinato inibe a enzima domínio prolil hidroxilase (PHD) estabilizando HIF-1 $\alpha$ (Tannahill et al., 2013). Desta maneira, realizamos o tratamento com creme acrescentado de ácido succínico à $3 \%$ na formulação e observamos que este induz aumento na espessura da pele de animais WT (Figura 20B, C). Além disso eliminamos o viés de que esse aumento na espessura da pele diante do tratamento com succinato pudesse ter ocorrido via independente da sinalização do Sucnr1, uma vez que o tratamento em animais $\mathrm{SUCNR}^{1 /-}$ não repercutiu em nenhuma alteração (Figura 21B, C).

Observamos que em condições de homeostase o Sucnr1 é expresso na pele de camundongos (Figura 14) em níveis basais, mas sua expressão aumenta significativamente na pele psoriática (Figura 5C, 14), sugerindo que o IMQ ou algum fator modulado por este induz a expressão do receptor o que associado à uma maior liberação de succinato pelas células em estresse contribui para ativação de queratinócitos. De alguma maneira a modulação dos queratinócitos via sinalização do Sucnr1 contribui para expansão de células produtoras de IL17 nos linfonodos drenantes, sugerindo que o receptor atua na fase inicial da doença e na manutenção do loop inflamatório.

Demonstramos que o Sucnr1 é expresso na pele de camundongos WT em níveis basais e que o IMQ aumenta tal expressão, que o receptor contribui para o desenvolvimento da psoríase uma vez que aspectos clínicos, histológicos e inflamatórios estão presentes em menores magnitudes nos animais SUCNR $1^{-/}$, confirmando assim sua importância na doença. Em seguida, observamos que o receptor é principalmente expresso por células de origem nãohematopoiéticas, por queratinócitos. A expressão do Sucnr1 por queratinócitos é um evento bioquímico essencial para o desenvolvimento da resposta inflamatória característica da psoríase. Após as investigações que nos permitiram essas conclusões, avaliamos o potencial do ligante de Sucnr1, tratamos a pele de animais WT com creme incorporado com ácido succínico, experimento no qual observamos aumento na espessura da pele dos animais. 


\section{CONSIDERAÇÕES FINAIS}

Concluímos que o Sucnr1 é expresso por queratinócitos e essa expressão se eleva na pele psoriática. O succinato sinaliza através de seu receptor em queratinócitos contribuindo para o efeito do IMQ induzindo produção de citocinas próinflamatórias local e sistemicamente e expansão de células produtoras de IL-17, o que resulta em maior hiperproliferação de queratinócitos ocasionando padrões patológicos observados como lesões características da psoríase, com edema, eritema, descamação, hiperqueratose, acantose, paraqueratose, bem como presença de intenso infiltrado inflamatório. Sendo assim, o Sucnr1 é um alvo farmacológico potencial para o desenvolvimento de uma terapia para tratamento da psoríase.

Nos próximos passos realizaremos uma curva dose-resposta com estímulo de succinato em células HaCaT, combinaremos o estímulo de IMQ com o estímulo de succinato, investigaremos o que induz a expressão do Sucnr1 em queratinócitos, avaliaremos quais citocinas e vias de sinalização são moduladas pela ativação do Sucnr1 e à qual proteína $\mathrm{G}$ está acoplado. Estamos em processo de construção de animais condicionalmente nocauteados para o Sucnr1 em queratinócitos $\left(\mathrm{K} 14^{\mathrm{Cre}} \mathrm{SUCNR} 1^{\text {flox/flox }}\right)$ e pretendemos ainda caracterizar a expressão do Sucnr1 na pele lesionada de pacientes com psoríase. 


\section{REFERÊNCIAS BIBLIOGRÁFICAS}

Aguiar CJ et al. Succinate causes pathological cardiomyocyte hypertrophy through GPR91 activation. Cell Communication and Signaling. 12:78-95, 2014.

Albanesi $\mathrm{C}$ et al. The Interplay Between Keratinocytes and Immune Cells in the Pathogenesis of Psoriasis. Frontiers in Immunology. 9:1-7, 2018.

Bata-Csorgo Z, Szell M. The psoriatic keratinocytes. Expert Review of Dermatology. 7:473$481,2014$.

Bernard FX et al. Keratinocytes under Fire of Proinflammatory Cytokines: Bona Fide Innate Immune Cells Involved in the Physiopathology of Chronic Atopic Dermatitis and Psoriasis. Journal of Allergy. 12:1-10, 2012.

Bjorkstrom NK et al. Emerging insights into natural killer cells in human peripheral tissues. Nature Reviews. 16:310-320, 2016.

Blauvelt A and Chiricozzi A. The Immunologic Role of IL-17 in Psoriasis and Psoriatic Arthritis Pathogenesis. Clinical Reviews in Allergy \& Immunology. 3:379-390, 2018.

Boehncke WH e Shon MP. Psoriasis. The Lancet. 386:983-94, 2015.

Boer $\mathrm{M}$ et al. Structural and biophysical characteristics of human skin in maintaining proper epidermal barrier function. Adv Dermatol Allergol. 1:1-5, 2016.

Cai Y, Shen X, Ding C et al. Pivotal Role of Dermal IL-17-Producing gd T Cells in Skin Inflammation. Immunity. 35:596-610, 2011.

Cai Y, Xue F, Quan C et al. A Critical Role of the IL-1beIL-1R Signaling Pathway in Skin Inflammation and Psoriasis Pathogenesis. Journal of Investigative Dermatology. 139:146-156, 2019.

Cho EH. Succinate as a Regulator of Hepatic Stellate Cells in Liver Fibrosis. Frontiers in Endocrinology. 9:1-5, 2018.

Coates $\mathrm{M}$ et al. Innate antimicrobial immunity in the skin: A protective barrier against bacteria, viruses, and fungi. PLOS Pathogens. 14:e1007353, 2018.

Di Meglio P, Perera GK e Nestle FO. The Multitasking Organ: Recent Insights into Skin Immune Funcion. Immunity. 35:857-869, 2011.

Diane M, Altomare G and Reali E. T Helper Cell Subsets in Clinical Manifestations of Psoriasis. Journal of Immunology Research. 1-7, 2016.

Duarte GV, Porto-Silva L e Oliveira MFP. Epidemiology and treatment of psoriasis: a Brazilian perspective. Psoriasis: Targets and Therapy. 5:55-64, 2015.

Fits L, Mourits S, Voerman JSA et al. Imiquimod-Induced Psoriasis-Like Skin Inflammation in Mice Is Mediated via the IL-23/IL-17 Axis. The Journal of Immunology. 182:58365845, 2009.

Flutter B e Nestle FO. TLRs to cytokines: Mechanistic insights from the imiquimod mouse model of psoriasis. European Journal of Immunology. 43:3138-3146, 2013.

Fonseca MC et al. GPR91: expanding the frontiers of Krebs cycle intermediates. Cell Communication and Signaling. 14:3-9, 2016.

Freedberg IM et al. Keratins and the Keratinocyte Activation Cycle. The Journal of Investigative Dermatology. 116:633-640, 2001. 
Furue M et al. Interleukin-17A and Keratinocytes in Psoriasis. Int J Mol Sci. 21:1275, 2020.

Gaffen SL, Jain R, Garg AV et al. IL-23-IL-17 immune axis: Discovery, Mechanistic Understanding, and Clinical Testing. Nature Reviews Immunology. 9:585-600, 2014.

Gilissen J et al. Insight into SUCNR1 (GPR91) structure and function. Pharmacology \& Therapeutics. 159:56-65, 2016.

Gordon S e Pluddemann. Tissue macrophages: heterogeity and functions. BMC Biology. 15:53, 2017.

Gottlieb AB. Psoriasis: Emerging therapeutic strategies. Nature Reviews Drug Discovery. 4:19-35, 2005.

Griffiths CEM et al. The global state of psoriasis disease epidemiology: a workshop report. $\mathbf{B r}$ J Dermatol. 177:e4-e7, 2017.

Grimolizzi F e Arranz L. Multiple faces of succinate beyond metabolism in blood. Haematologica. 103:1586-1592, 2018.

$\mathrm{He} \mathrm{W}$ et al. Citric acid cycle intermediates as ligands for orphan G-protein-coupled receptor. Nature. 429:188-194, 2004.

Kabashima $\mathrm{K}$ et al. The immunological anatomy of the skin. Nature Reviews Immunology. 19:19-30, 2019.

Kanitakis J. Anatomy, histology and immunohistochemistry of normal human skin. European Journal of Dermatology. 4:1-12, 2002.

Kim $S$ et al. Global Metabolite Profiling of Synovial Fluid for the Specific Diagnosis of Rheumatoid Arthritis from Other Inflammatory Arthritis. PLOS One. 9:e97501, 2014.

Kirfel G e Herzog V. Migration of epidermal keratinocytes: mechanisms, regulation, and biological significance. Protoplasma. 223:67-78, 2004.

Kominsky DJ, Campbell EL e Colgan SP. Metabolic Shifts in Immunity and Inflammation. J Immunol. 148:4062-4068, 2010.

Leigh IM, Navsaria H, Purkis PE et al. Keratins (K16 and K17) as markers of keratinocyte hyperproliferation in psoriasis in vivo and in vitro. The British Journal of Dermatology. 4:501-511, 1995.

Li ZJ, Sohn KC, Choi DK et al. Roles of TLR7 in Activation of NF-kB Signaling of Keratinocytes by Imiquimod. PLOS One. 10, 2013.

Lowes MA, Suarez-Farinas M e Krueger JG. Immunology of Psoriasis. Ann Rev Immunol. 32:227-255, 2014.

Luckheeram RV et al. CD4+ T Cells: Differentiation and Functions. Clinical and Developmental Immunology. 12:1-12, 2012.

Macri C et al. Dendritic cell subsets. Seminars in Cell \& Developmental Biology. 84:11-21, 2018.

Mahil SK, Capon F e Barker JN. Update on psoriasis immunopathogenesis and targeted immunotherapy. Semmin Immunopathol. 38:11-27, 2016.

Mallbris L, O’Brien KP, Hulthén A et al. Neutrophil gelatinase-associated lipocalin is a marker for dysregulated keratinocyte differentiation in human skin. Experimental Dermatology. 11:584-591, 2002. 
Mann ER et al. Review: Skin and the Immune System. J Clin Exp Dermatol Res. 1-16, 2012.

McCreath KJ et al. Target Disruption of the SUCNR1 Metabolic Receptor Leads to Dichotomous Effects on Obesity. Diabetes. 64:1154-1167, 2015.

Melo BMS. Alarmina S100A9: um mediador crítico no desenvolvimento da psoríase. 2017. Dissertação (Mestrado em Imunologia Básica e Aplicada) - Faculdade de Medicina de Ribeirão Preto, Universidade de São Paulo, Ribeirão Preto, 2017;

Mills E, O’Neill LAJ. Succinate: a metabolic signal in inflammation. Trends in Cell Biology. 24:313-320, 2014.

Moos S, Mohebiany AN, Waisman A. Imiquimod-Induced Psoriasis in Mice Depends on the IL-17 Signaling of Keratinocytes. Journal of Investigative Dermatology. 139:11101117, 2019.

Nestle et al. Skin immune sentinels in health and disease. Nature Reviews Immunology. 9:679-691, 2009.

Nguyen AV e Soulika AM. The Dynamic of the Skin's Immune System. Int J Mol Sci. 20:1811-1864, 2019.

O’Neill LAJ, Kishton RJ e Rathmell J. A guide to immunometabolism for immunologists. Nature Reviews Immunology. 16:553-566, 2016.

Ogawa $\mathrm{Y}$ et al. Zinc in Keratinocytes and Langerhans Cells: Relevance to the Epidermal Homeostasis. Journal of Immunology Research. 18:1-11, 2018.

Orecchioni $\mathrm{M}$ et al. Macrophage Polarization: Different Gene Signatures in M1(LPS+) vs. Classically and M2(LPS-) vs. Alternatively Activated Macrophages. Frontiers in Immunology. 10:1-14, 2019.

Papayannopoulos V. Neutrophil extracellular traps in immunity and disease. Nature Reviews Immunology. 18:134-147, 2018.

Perera GK, Di Meglio P e Nestle FO. Psoriasis. Annual Review of Pathology, 7, 385-422, 2012.

Pivarcsi A, Nagy I e Kemeny L. Innate Immunity in the Skin: How Keratinocytes Fight Against Pathogens. Current Immunology Review. 1:29-42, 2005.

Puleston DJ, Villa M e Pearce EL. Ancilary Activity: Beyond Core Metabolism in Immune Cells. Cell Metabolism. 26:131-142, 2017.

Rigas et al. Psychological Stress and Depression in Psoriasis Patients - a Dermatologist's Perspective. Maedica. 14:287-291, 2019.

Romiti R et al. Prevalence of psoriasis in Brazil - a geographical survey. International Journal of Dermatology. 56, 2017.

Rosenblum MD, Remedios KA e Abbas AK. Mechanisms of human autoimmunity. Journal of Clinical Investigation, 125:2228-2233, 2015.

Rubic-Schneider T et al. Triggering the succinate receptor GPR91 on dendritic

cells enhances immunity. Nature Immunology. 9:1261-1269, 2008.

Sapieha $\mathrm{P}$ et al. e succinate receptor GPR91 in neurons has a major role in retinal angiogenesis. Nature Medicine. 14:1067-1077, 2008.

Saraiva Al et al. Succinate receptor deficiency attenuates arthritis by reducing dendritic cell traffic and expansion of Th17 cells in the lymph nodes. FASEB. 6550-6559, 2018. 
Saravia J, Chapman NM e Chi H. Helper T cell differentiation. Celular \& Molecular Immunology. 1-10, 2019.

Scher $\mathbf{J}$ et al. Preventing psoriatic arthritis: focusing on patients with psoriasis at increased risk of transition. Nature Reviews Rheumatology. 15:153-167, 2019.

Selak, M.A. et al. Succinate links TCA cycle dysfunction to oncogenesis by inhibiting HIFalpha prolyl hydroxylase. Cancer Cell. 7:77-85; 2005.

Siebenhaar F et al. Mast Cells as Drivers of Disease and Therapeutic Targets. Trends in Immunology. 2017.

Sumpter TL, Balmert SC e Kaplan DH. Cutaneous immune responses mediated by dendritic cells and mast cells. JCI Insight. 4:e123947, 2019.

Suter MM et al. Keratinocyte biology and pathology. Veterinary Dermatology. 8:67-100, 1997.

Tannahill, G.M. et al. Succinate is an inflammatory signal that induces IL-1beta through HIF1alpha. Nature. 496:238-242, 2013.

Tilg H, Moschen AR. Adipocytokines: mediators linking adipose tissue, inflammation and immunity. Nature Reviews Immunology. 6:772-783, 2006.

Tretter L, Patocs A e Chunopoulos C. Succinate, an intermediate in metabolism, signal transduction, ROS,hypoxia, and tumorigenesis. Biochimica et Biophysica Acta. 1857:1086-1101, 2016.

Tsepkolenko A et al. The regenerative potential of skin and the immune system. Clinical, Cosmetic and Investigational Dermatology. 12:519-532, 2019.

Vantourout P e Hayday A. Six-of-the-best: unic contributions of $\gamma \delta$ T cells to immunology. Nature Reviews Immunology. 13:88-100, 2013.

Vargas SL et al. Activation of the Succinate Receptor GPR91 in Macula Densa Cells Causes Renin Release. J Am Soc Nephrol. 20:1002-1011, 2009.

Wagner et al. Psoriasis: what we have learned from mouse models. Nature Reviews. 6:704415, 2010.

Wang A, Luan HH e Medzhitov R. Na evolutionary perspective on immunometabolism. Science. 363:1-10, 2019.

Wang S, Song R, Wang Z et al. S100A8/9 in Inflammation. Frontiers in Immunology. 9:114, 2018.

Wickett RR e Visscher MO. Structure and function of the epidermal barrier. AJIC. 34:98-110, 2006.

Wong R et al. The dynamic anatomy and patterning of skin. Experimental Dermatology. 25:92-98, 2015.

World Health Organization. Global report on psoriasis, 2016.

Wynn TA, Chawla A e Pollard JW. Origins and Hellmarks of Macrophages: Development, Homeostasis, and Disease. Nature. 496:445-455, 2013.

Zarin $\mathrm{P}$ et al. Gamma delta T-cell differentiation and effector function programming, TCR signal strength, when and how much? Cellular Immunology. 1-6, 2015. 


\section{ANEXOS}

\subsection{Comitê de Ética}

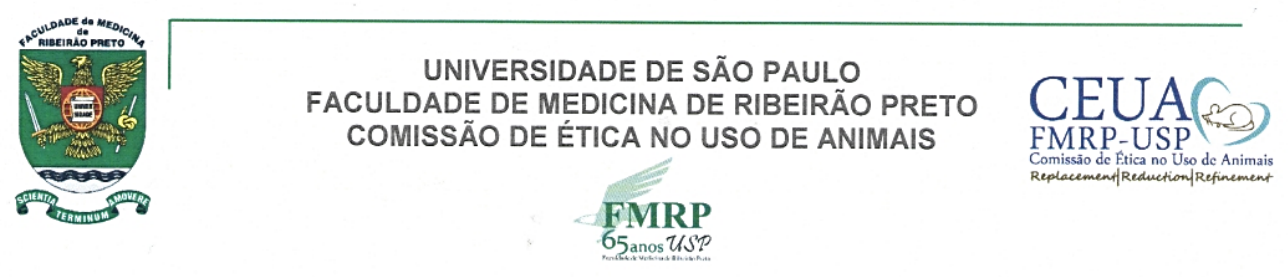

\section{CER TIF I C A D O}

Certificamos que o Protocolo intitulado "Papel do Receptor de Succinato 1

(SUCNR1/GPR91) na Imunopatologia da Psoríase", registrado com o número 111/2019, sob a responsabilidade do Prof. Dr. José Carlos Farias Alves Filho, envolvendo a produção, manutenção ou utilização de animais pertencentes ao filo Chordata, subfilo Vertebrata (exceto humanos) para fins de pesquisa científica, encontra-se de acordo com os preceitos da Lei $n^{\circ} 11.794$ de 8 de outubro de 2008, do Decreto ${ }^{\circ} 6.899$ de 15 de julho de 2009 e com as normas editadas pelo Conselho Nacional de Controle de Experimentação Animal (CONCEA), e foi APROVADO pela Comissão de Ética no Uso de Animais da Faculdade de Medicina de Ribeirão Preto da Universidade de São Paulo em reunião de 29 de julho de 2019.

Este Protocolo prevê a utilização de 240 camundongos C57Bl 6 machos pesando $20 \mathrm{~g}$ oriundos do Serviço de Biotério da Prefeitura do Campus de Ribeirão Preto da Universidade de São Paulo; 114 camundongos GPR-91 KO machos pesando 20g oriundos do Centro de Criação de Camundongos Especiais da Faculdade de Medicina de Ribeirão Preto da Universidade de São Paulo e 84 camundongos CD11c-DTR/GFP machos pesando 20g oriundos dos Laboratórios Jackson (EUA). Vigência da autorização: 29/07/2019 a 31/07/2025.

We certify that the Protocol $n^{\circ} 111 / 2019$, entitled "Role of Succinate Receptor 1 (SUCNRI/GPR91) in the Immunopathology of Psoriasis", is in accordance with the Ethical Principles in Animal Research adopted by the National Council for the Control of Animal Experimentation (CONCEA) and was approved by the Local Animal Ethical Committee from Ribeirão Preto Medical School of the University of São Paulo in 07/29/2019. This protocol involves the production, maintenance or use of animals from phylum Chordata, subphylum Vertebrata (except humans) for research purposes, and includes the use of 240 male C57Bl 6 mice weighing $20 \mathrm{~g}$ from the Central Animal House of Ribeirão Preto Medical School; 114 male GRP-91KO mice weighing 20g from the Breeding Center of Special Mice of Ribeirão Preto Medical School, University of São Paulo and 84 male CD11c-DTR/GFP mice weighing 20g from the Jackson Laboratory (Bar Harbor, ME, EUA). This certificate is valid until 07/31/2025.

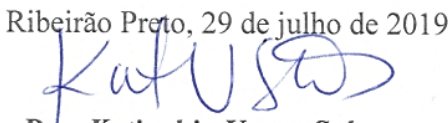

Profa. Dra. Katiuchia Uzzun Sales Coordenadora da CEUA-FMRP - USP 